\title{
In vivo and in vitro characterization of colorectal cancer cells
}

Citation for published version (APA):

Verstijnen, C. P. H. J. (1987). In vivo and in vitro characterization of colorectal cancer cells. [Doctoral Thesis, Maastricht University]. Rijksuniversiteit Limburg. https://doi.org/10.26481/dis.19871204cv

Document status and date:

Published: 01/01/1987

DOI:

$10.26481 /$ dis. $19871204 \mathrm{cv}$

Document Version:

Publisher's PDF, also known as Version of record

\section{Please check the document version of this publication:}

- A submitted manuscript is the version of the article upon submission and before peer-review. There can be important differences between the submitted version and the official published version of record.

People interested in the research are advised to contact the author for the final version of the publication, or visit the DOI to the publisher's website.

- The final author version and the galley proof are versions of the publication after peer review.

- The final published version features the final layout of the paper including the volume, issue and page numbers.

Link to publication

\footnotetext{
General rights rights.

- You may freely distribute the URL identifying the publication in the public portal. please follow below link for the End User Agreement:

www.umlib.nl/taverne-license

Take down policy

If you believe that this document breaches copyright please contact us at:

repository@maastrichtuniversity.nl

providing details and we will investigate your claim.
}

Copyright and moral rights for the publications made accessible in the public portal are retained by the authors and/or other copyright owners and it is a condition of accessing publications that users recognise and abide by the legal requirements associated with these

- Users may download and print one copy of any publication from the public portal for the purpose of private study or research.

- You may not further distribute the material or use it for any profit-making activity or commercial gain

If the publication is distributed under the terms of Article $25 \mathrm{fa}$ of the Dutch Copyright Act, indicated by the "Taverne" license above, 
IN VIVO AND IN VITRO CHARACTERIZATION OF COLORECTAL CANCER CELLS 
Graphic design by Rarin Daniëls Printed by $T_{n} O$. Offset 


\title{
IN VIVO AND IN VITRO CHARACTERIZATION OF COLORECTAL CANCER CELLS
}

\author{
PROEFSCHRIFT
}

ter verkrijging van de graad van Doctor in de Geneeskunde aan de Rijksuniversiteit Limburg te Maastricht, op gezag van de Rector Magnificus, Prof. Dr. F.I.M. Bonke, volgens het besluit van het College van Dekanen, in het openbaar te verdedigen op vrijdag 4 december 1987, des namiddags

$$
\text { om } 16.00 \text { uur }
$$

door

Cornelis Petrus Henricus Josephus Verstijnen

geboren te Tilburg in 1953 
Promotor: Prof. Dr. F.T. Bosman

Co-promotor: Dr. J.W. Arends

Referenten: Prof. Dr. J.P.M. Geraedts

Prof. Dr. D.J. Ruiter

Dr. J. Hilgers

Dit onderzoek werd mede mogelijk gemaakt door een subsidie van het Koningin Wilhelmina Fonds (RL 82-1). De publicatie van het proefschrift werd financieel ondersteund door de Stichting Klinische Pathologie Limburg. 
Aan mijn ouders 


\section{CONTENT}

GENERAL INTRODUCTION 1

1. Introduction 2

2. Colorectal cancer cell characteristics 2

2.1. Antigen expression 3

2.1.1. Carcinombryonic Antigen (CEA) 4

2.1.2. Monoclonal antibody defined-tumor antigens (GICA) 4

2.1.3. Monoclonal antibody defined differentiation
antigens

3. Model studies for colorectal cancer 6

3.1. Model for normal human colon 6

3.2. Model studies of colon cancer 7

3.2.1. Tissue culture 7

3.2.2. Nude mouse model 7

3.3. Tumor cell heterogeneity 8

II COLORECTAL (CANCER) TISSUE ASSOCIATED ANTIGENS 11

1. Introduction 12

2. CEA-specificity of CEA reactive monoclonal antibodies.

Immunochemical and immunocytochemical studies. 13

2.1. Introduction 13

2.2. Material and methods 14

2.3. Results 18

2.4. Discussion 23

3. Distribution of monoclonal antibody defined monosialoganglioside in normal and cancerous human tissues:

an immunoperoxidase study. 29

3.1. Introduction 29

3.2. Material and methods 29

3.3. Results $\quad 30$

3.4. Discussion 36 
4. Monoclonal antibody defined mucin antigens of normal and neoplastic human colonic mucosa: Biochemicall and histochemical characterization.

4.1. Introduction 41

4.2. Material and methods 40

4.3. Results 45

4.4. Discussion 51

5. Tissue distribution of mucin reactive monoclonal antibodies in normal and neoplastic human tissue 56

5.1. Introduction 56

5.2. Material and methods 57

$\begin{array}{lll}\text { 5.3. Results } & 58\end{array}$

5.4. Discussion 67

MODEL STUDIES IN COLORECTAL CANCER 73

$\begin{array}{lll}\text { 1. Introduction } & 74\end{array}$

2. Xenografting of normal colonic mucosa in athymic mice. 75

2.1. Introduction 75

2.2. Material and methods 75

$\begin{array}{lll}\text { 2.3. Results } & 77\end{array}$

2.4. Discussion 83

3. Culturing and xenografting of primary colorectal carcinoma cells: comparison of in vitro and in vivo model and primary tumor. 86

3.1. Introduction 86

3.2. Materials and methords 87

3.3. Results $\quad 89$

3.4. Discussion 98 
4. The establishment and characterization of two new cell lines derived from a single colonic adenocarcinoma. 102

$\begin{array}{ll}\text { 4.1. Introduction } & 102\end{array}$

4.2. Materials and methods 102

4.3. Results 105

4.4. Discussion 113

$\begin{array}{ll}\text { GENERAL DISCUSSION } & 117\end{array}$

$\begin{array}{ll}\text { SUMMARY } & 126\end{array}$

$\begin{array}{ll}\text { SAMENVATTING } & 129\end{array}$

$\begin{array}{ll}\text { PUBLICATIELIJST } & 132\end{array}$

$\begin{array}{ll}\text { DANKWOORD } & 134\end{array}$

$\begin{array}{ll} & 135\end{array}$ 


\section{GENERAL INTRODUCTION}




\section{INTRODUCTION}

In Western countries the large bowel belongs to the main sites of origin of cancer. Colorectal cancer ranks second in incidence after breast carcinoma in women and lung cancer in men (1). Mortality of colorectal cancer is mainly due to the development of liver metastasis within five years after operation in about $50 \%$ of all patients. In addition, important morbidity is caused by local recurrence. Despite the advent of new therapeutic modalities, such as more refined operation techniques, radiotherapy, chemotherapy and immunotherapy, the outlook of large bowel cancer patients has hardly improved over the past two or three decades (2-5). It is obvious, therefore, that research on large bowel cancer should be primarily aimed at a major breakthrough in therapy and prevention. To achieve this goal, however, more fundamental knowledge about the biologic characteristics of the cancer cells in relation to the behaviour of large bowel carcinoma is mandatory.

\section{COLORECTAL CANCER CELL CHARACTERISTICS}

One of the problems of colorectal carcinomas is that their clinical course and response to therapy is diverse and rather unpredictable despite their fairly uniform morphological - features. Historically, the Dukes classification describing the stage of extension of the disease has been used as a strong prognostic indicator (6). Using this classification four categories with a different prognosis in terms of patient survival can be established (table I) (7).

Table 1. Five years survival of patients with different Dukes stages

\begin{tabular}{llc}
\hline Dukes & \multicolumn{1}{c}{ Extension } & \% Survival \\
\hline A & $\begin{array}{l}\text { up to muscularis propria } \\
\text { without metastasis }\end{array}$ & 92 \\
B & $\begin{array}{l}\text { throughout bowel wall } \\
\text { without metastasis }\end{array}$ & 76 \\
C & $\begin{array}{l}\text { A }+ \text { B, with lymphnode } \\
\text { metastasis }\end{array}$ & 55 \\
D & $\begin{array}{l}\text { growth into adjacent organs } \\
\text { distant metastasis }\end{array}$ & 17 \\
\hline
\end{tabular}


As illustrated by this table the chances of survival for individual patients within each Dukes category are variable. Important questions which remain are:

a. why do $24 \%$ of Dukes $B$ patients not reach a 5 years survival. b. why do $55 \%$ of Dukes $\mathrm{C}$ patients demonstrate a relatively benign clinical course?

The stage of tumor extension may be correlated with the lag of time between the initiating event in the development of the tumor and its discovery and therefore may not be primarily related to the biological characteristics of the tumor in terms of invasive and/or metastatic potential.

One tumor cell characteristic that has been shown to be of prognostic significance is the grade of differentiation of the carcinoma cells (8). Patients with poorly differentiated or undifferentiated carcinomas generally show a more aggressive clinical course in comparison with patients with moderately or well differentiated carcinomas although exceptions occur (9). Poorly differentiated and undifferentiated colorectal carcinomas, however, only form a minority of al』 large bowel carcinomas and therefore histological grading is of limited value. Moreover, intratumor heterogeneity in histological grade occurs (10). Also the criteria for grading are ill defined and remain rather subjective (8). Since these factors hamper accurate and consistent assessment of the grade of differentiation in colorectal carcinomas it is necessary to search for other tumor cell characteristics enabling the identification of metastasizing and locally recurring tumors.

\subsection{Antigen expression}

Phenotypic features of colorectal cancer cells have been studied by means of various histochemical and especially immunohistochemical staining techniques (11). With the use of these techniques it has become possible to determine the expression of different antigens in carcinomas in relation to their clinical course in patients.

Especially after the advent of the hybridoma technique (12) to generate monoclonal antibodies a wide variety of antigens has been explored. Antigens used for the study of colorectal carcinoma can be divided into two groups:

1. antigens mainly occurring in neoplastic colonic epithelial cells, which can be designated as tumor-associated antigens. The 
relation to cell structure or function of such antigens is usually not or incompletely known.

2. antigens, mainly occurring in normal colonic epithelial cells which can be designated as differentiation antigens. The relation to cell structure and function of these antigens is usually well known.

\subsubsection{Carcinoembryonic Antigen (CEA)}

The prototype of a tumor associated antigen is carcino-embryonic antigen (CEA) which is synthesized by the majority of colorectal carcinomas and to a variable extent secreted into the circulation. The antigen, however, appears to occur as a normal constituent of colonic mucosa and is expressed with increased levels in various non malignant diseases $(13,14)$. Several studies have shown that this marker is useful in the early detection of tumor recurrence and therefore the current role of CEA in colorectal cancer is limited to follow-up (15). A major problem, however, in this area has been that CEA consists of a family of glycoproteins which differ primarily with regard to the degree of glycosylation. Furthermore, many cross reacting antigens have been discovered which compromise its use as a tumor associated antigen (for review see 16). Recently, CEA reactive monoclonal antibodies have been reported, which are claimed to be reactive with specific epitopes restricted to the CEA molecule $(17,18)$. Use of such monoclonal antibodies may be valuable for further studies on the prognostic significance of CEA. Chapter II-2 describes the generation and characterization of a series of CEA reactive monoclonal antibodies. We investigated reactivity of the monoclonal antibodies with $\mathrm{CEA}$ and crossreacting antigens in biochemical and in immunoperoxidase assays in order to investigate the specificity for antigenic determination of CEA.

\subsubsection{Monoclonal antibody defined tumor antigen (GICA)}

On the basis of the assumption that monoclonal antibodies could be raised against tumor or organ specific antigens warious groups have generated monoclonal antibodies against colorectal carcinoma tissue and derived cell lines. Biochemical characterization of monoclonal antibody reactive antigens, however, has often proved to be difficult and cumbersome. Immunocytochemical characterization is necessary to explore the tissue distribution of the antigens and/or epitopes for the assessment of tissue or tumor specificity. In the past claims have been made of the generation of monoclonal antibodies recognizing 
tumor specific antigens. Such claims, however, needed more substantial exploration and characterization of the biochemical nature and the tissue distribution of the antigens. The fate of $\mathrm{Ca} 19-9$ originally designated gastrointestinal cancer associated antigen (GICA), illustrates these problems. This monoclonal antibody has been raised against the SW 1116 colorectal cancer cell line and on the basis of incomplete characterization was claimed to be specific for gastrointestinal neoplasms (19). The epitope recognized by this monoclonal antibody was originally reported to reside on a monosialoganglioside molecule but later on also appeared to occur on molecules of mucin nature (20). Ca 19-9 is now widely applied in the serological and immunoscintigraphic diagnosis of gastrointestinal cancer. In Chapter II-3 we describe an extensive immunocytochemical survey of the reaction pattern of this monoclonal antibody in various tissues showing that $\mathrm{Ca} 19-9$ occurs in variety of normal and neoplastic tissues.

\subsubsection{Monoclonal antibody defined differentiation antigens}

As has been described in the previous paragraph, initially in the search for tumor specific antigens, carcinoma tissue has been mainly used for the generation of monoclonal antibodies. An other approach would be to study the biological and clinical significance of normal cellular differentiational characteristics in colorectal cancer cells. In the field of malignant lymphomas this approach has proven to be of value $(21,22)$. In normal colonic mucosa three mature cell types can be distinguished: mucin producing goblet cells, resorptive cells and endocrine cells. At present data are in favour of the concept of the unitarian stem cell for intestinal epithelium (23, 24). The interrelation between immature stem cell and maturating cells has been established and described by Chang and Leblond $(25,26)$. Stem cells in the crypt base divide and give rise to precursor cells which multiply and differentiate into the three distinct cell types. All differentiated cells therefore originate from the same stem cell population. Since the origin and development of colorectal neoplasms may partly follow the lines of normal differentiation, it would be of value to identify antigens reflecting various stages of differentiation and maturation. Monoclonal antibodies against normal colonic crypt cells or antigen preparations have already been reported. Study of such monoclonal antibodies showed that various types of goblet cells exist (27) and that alterations in mucin composition occur in neoplastic colonic tissue $(28,29)$. In an attempt to generate monoclonal antibodies against antigens associated with 
goblet cell differentiation we used cell line 5583-S (30), which contains goblet cell characteristics, as immunogen.

The chapters II-4 and II-5 deal with the biochemical and immunohistochemical characterization of the monoclonal antibodies we obtained.

\section{MODEL STUDIES FOR COLORECTAL CANCER}

Determination of the antigen expression pattern of cells in a resected human colon carcinoma specimen only provides information on the phenotypic characteristics of the tumor at the time of operation. These phenotypic features may predict a distinct clinical course $(31,32)$ but do not shed much light on more fundamental biological characteristics of tumor growth. In view of the unpredictability of the biological behaviour of individual colonic tumors it is necessary to study the behaviour of malignant cells during progression in order to determine the growth characteristics, the metastatic potential and the sensitivity to therapy. In addition, it is crucial to study the processes in the carcinoma preceeding the time of diagnosis. Models, which allow study of the development of tumor cell characteristics in time and which allow manipulation of tumor cell growth conditions are necessary to gather information about the dynamics of colorectal cancer growth. Questions that could be answered in such a model system are:

- What determines invasive potential?

- Which mechanisms are involved in metastasis?

- Is metastases a selective process?

- Is tumor progression due to selection of variant subclones?

- Is therapy resistance due to selection?

\subsection{Model for normal human colon}

As discussed in paragraph 2.1.3. the origin of colorectal tumor cells may be a reflection of the histogenesis of normal colonic epithelial cell lines. Therefore a classification of large bowel carcinoma cells might conceivably be based on models of the interrelation and stages of maturation of normal colonic epithelial cells. To this end, however, more information about the exact stages of differentiation and maturation of normal epithelium is required. With the discovery that nude mice were athymic and lack $T$-cell 
mediated immune response a model for xenografting of human tissue was available (33). Therefore we implanted normal human colon into athymic mice and harvested xenograft at 5 weekly intervals to study the development of the epithelium in time. In chapter III-2 we describe the results of the implantation of normal colon mucosa into nude mice.

\subsection{Model studies of colon cancer}

\subsubsection{Tissue culture}

Tissue culture of tumors is nowadays widely applied in cancer research since it allows manipulation of cells under controlled conditions. As such it is a well established tool for the study of the effects of chemotherapy and radiotherapy on tumor cells. Many colorectal cancer cell lines have been described in the literature during the past decade (34).

One of the limitations of cell culture is that only a small proportion of colon carcinomas can be cultivated, so that selection of certain types of cells may have occurred in the successfully established cultures. Originally a succes rate of only $10 \%$ of colorectal tumors was reported (35), but more refined culture techniques and the addition of vitamines, hormones and growth factors to the culture medium has increased the succes rate to about $30 \%$ (36). Another limitation is that in tissue culture interaction wilh stromal components can not be studied. That these components are important for normal growth and differentiation has been shown by the stimulatory effect of fibroblast on tumor take rate in cell culture (37). Further more, extracellular matrix is necessary to obtain archilectural organisation of the cells in culture, comparable to the in vivo situation (38). Therefore tissue culture remains a rather artificial system. In this context the nude mouse model may be more suitable for the study of growth and differentiation of tumor cells and the interaction with the surrounding stromal matrix and cellular components.

\subsubsection{Nude mouse model}

The take rate of human cells in nude mice generally appears to be higher than in cell culture (39), but the rate of succes of nude mice xenografting may be limited by e.g. the occurrence of natural killer cells and active macrophages in these animals (40). The morphology of xenografts of human colon tumors, generally 
appears to be comparable to the original tumor, although a somewhat lesser degree of differentiation has been observed. Little information can be found in the literature about the comparison of phenotypic and genotypic features of human colorectal carcinoma cells in cell culture, nude mice xenografts and the original tumor.

As only a small proportion of the colon carcinoma can be successfully xenografted or cultured, it might be possible that in in vitro and in vivo models only a subpopulation of tumors will grow. Furthermore, it is questionable to what extent the in vitro and in vivo models resemble the primary tumor. Therefore we tried to establish cellines and xenograft from a large series of tumors and compared clinicopathological data from tumors that resulted in cell lines from those who could not be grown in vitro and in vivo (Chapter III-3). In addition we compared genotypic and phenotypic characteristics of original tumors and xenograft.

\subsection{Tumor cell heterogeneity}

Although since a long time there were indications for the existence of intratumoral heterogeneity from phenotypic and genotypic features $(41,42)$ of the tumor cells, only after culturing different cell lines from one tumor definite proof for the existence of heterogeneous clones in one tumor was obtained (43-45). Along with several other groups we have been able to propagate genetically different cell lines from one tumor. Chapter III-4 deals with the further characterization of these cell lines in respect of their genotype, phenotype and growth characteristics. 


\section{References}

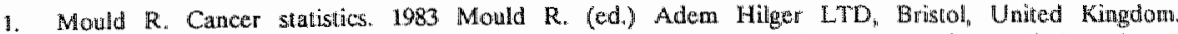

2. Tepper JE, Cohen AM, Wood WC, Orlow EL. Hedberg SE Postoperative radhation therapy of rectal cancer. Int. J. Rad. Onc. Biol. Phys. 1987, 13: 5-10.

3. Taylor 1 , Machin $D_{n}$ Mullert $M$, Trotter $G$, Cooke $T$, West $C$. A randonized conurolled trial of adjuxant portal vein cytotoxic perfusion in colorectal cancer. Br. I. Stifg. 1985, $72.359-363$

4. Turmbull RB Jr, Kyle $K$, Watsan $F R$, Spratt $J$ Cancer of the colon: the influence of the no-touch isolation technique on surviwal rates. Ann. Surg. 1967, 166: 4204427.

5. Gastrointestinal Study Group. Prolongation of the disease-free interval in surgically trented rectal carcinoma. N. Engl. J. Med. 1985, 312: 1405-1412.

6. Dukes $C_{\mathrm{p}}$ Bussey HIR. The spread of rectal cancer and its elfect on progaosis. Br. J. Cancer $1958,12: 309-320$.

7. Wiggers T, Arends JW, Schutte B, Volovics L, Bosman FT, A multikariate analysis of pathological prognostic indicators in large bowel ancer. Cancer (in press).

8. Blenkinsopp WK, Stewart-Brown $S$, Blesowsky $L$, Kearmey $G_{8}$ Fielding L.j. Histopathology reporting in large bowel cancer. J. Clin. Pathol. 1981, 34: 509-513.

9. Gibbs NM. Undifferentiated carcinowa of the large intestine. Histopathology 1977, 1: 7784.

10. Qualheim RE, Gall EA. Is histologic grading of colon cancer a valid procedure? Arch. Pathol. 1975, 56: 466-472.

11. Arends JW, Bosman FT, Higgers J. Tissue antigens in large bowel cancer. Biochin. Biophys. Acta. 1985: 780: 1-19.

12. Kithler $G$, Milstein $C$. Coninuous cultures of fused cells secreting antibodies of predellned specificity. Nature 1975, 256: $495-497$.

13. Primus FJ, Clark CA, Goldenberg DM. Immunoperoxidase localization of carcinocmbryo nic antigen in normal human intestinal mucosa. JNCI 1981, 67; $1031-1039$.

14. Goldenberg DM, Sharkey RM, Primus FJ. Carcinoembryonic antigen in histopalloology: unmunoperoxidase staining of conventional tissue sections. JNCr 11976,57 . 11-22.

15. Mach JP. Carcinoembryonic antigen (CEA), deflunition, specificity and clinical application. In: Tumor markers: impacts and prospects, E. Boelsma, Ph Rumpke (eds.) 1977: 119-149, North Holland Biomed. Press.

16. Rogers GT. Carcinoembryonic antigens and related glycoproteins molecular aspects in specificity. Biochim. Bioplys. Acta 1983, 695: 227-249.

17. Wagener $C$, Joy Yang $Y H$, Crawford FG, Shively JE. Monodonal antibodies for carcinoembryonic antigen and related antigens as a model system; a systematic approach for the detcrmina tion of epitope specificity of monoclonal antibodies. J. Immanol, 1983, 130: $2308-2315$.

18. Haskefl $C M_{*}$ Bucheggen $F$, Schreyer $M$, Carrel $S$, Mach JP. Monoclonal antibodies lo wacino-

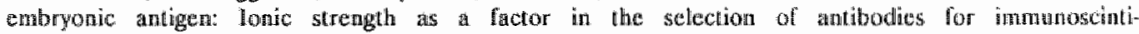
graphy. Cancer Res. 1983, 43: 693-701.

19. Koprowski $H_{n}$ Herlyn $M_{*}$ Steplewski $Z$. Sears HF. Specific antigen in serum of pattients with colon cancer. Scicace 1981, 212: 53.55

20. Magnani JL, Brockhaus M, Smith DF, Ginsburg V, Blaszzyk M, Mitchell KF "Stcplewski Z, Koprowaki H. A monosialoganglioside is monoclonal antibody-defined antigen in colon carcinoma. Science 1981, 212: 55-56.

21. Lukes RJ, Parker NW, Taylor $\mathrm{CR}$, Tindle $\mathrm{BH}$, Cramer $\mathrm{AD}$, Lincoln TL. Immunologic approach to nom Hodgkin's lymphomas and related leukemias: analysis at the resulls of mulliparanueter studies of 425 cases. Sem. Hematol. 1978, 15: 322-351.

22. Stein H. The immunologic and immunochemical basis for the Kiel classification. In: Malignanat lymphowas other than Hodgkin's disease. Verlinger CE (ed.) Springer Verlag, Berlin ${ }_{\text {" }}$ (n78: $529-656$.

23. Andrew A, Kramer B, Rawdon BB. T'the embryonic origin of endocrine cells of the gastrointestinal tract. Gen. Comp. Endocrinol. 1982, 47; 249-265.

24. Cheng $H$, Leblond $C P$. Origin differentiation and renewal of the four main epitheliat cetl lypes in the mouse small intestine. $V$. Unitarian theory at the origin of the four cpithuliat cell types. Am. J. Anat. 1974, 141: 537-562.

25. Chang WWL, Leblond CP. Renewal of the epithelial cells in the descending colon of the mouse. 1. Presence of three cell populations vacuolated columnar, mucous and arigentalfin. Am. J. Anat 1971, 131: 73-100. 
26. Ching WWL, Leblend CP. Renewal of the epithelial cellis in the descending colon of the mousc. U. Rencwal of argentuffin cells. Am. J. Anat, 1971, 131: 101-110.

27. Podolsky DK, Lymch $K$, Fournier DA. Development at ani human colonic mucin monoclonal antibodies. Chatucterixation of multiple colonic mucin species. J. Clin. linvest. 1986, 77 : $1251-1262$

28. Hudges $\mathrm{NR}$, Walts RS, Neland CR, Payne JE Antigen expression in normal and neoplasite colonic roucosa: The lissue specific antigens using monodonal antibodies 10 isolated colonic gliands. Cancer $\mathbb{R e s}$. 1986, 46: $2164-2171$.

29. Richman Pl, Bodmef WF. Moncclonal antibodies to human colorectal epithelium: markers for dafferentiation and tumor characterization. Int. J. Cancer $1987,39 \% 317,328$.

30. Verstijnen CPHJ, hends JW, Moerkerk PTM, Geraedis JPM, Sekikawa K, Uitendaal MP, Bosman FT. The establishment and characterization of two new cell lines derived from a single colonic adenocalinoma. Virch. Arch. B. 1987, in press.

31. Arends IW, Wiggers "T, Thijs CT, Versijinen $C$, Swaen GJV, Bosman FT. The value of secretory componesul (SC) ummunoreactivity in diagnosis and prognosîn of colorechal cancer. Am. 1. Clin. Pathol 1984, 82; 267.274.

32. Wiggers T, Arends JW, Verstijnen $C_{n}$ Moerkerk PM, Bosman. FT. Prognositic significance of CEA inmmoreactivity patterns in large bowel carciomo tissue. Bir. J. Cancer 1986, 54: $409-414$.

33. Pantelenous EM. Nature 1968, 217: 370-371.

34. Rulkky L.P. The biology of human colon tumor cells in tissue culture. Advances Cell Culture $1985,4: 47-83$.

35. Leibovitz A, stinson JC, McCombs WB MeCoy CE, Mazur KC Mabry ND. Classificalion of thuman colorectal adenocarcinoma cell lines. Cancer Res. 1976, 36: 4562-4569.

36. McBain J, Weese JL, Meisner LF, Walberg WH, Willson JKV. Establishment and characterization of colorectal cancer cell lines. Cancer Res. 1984, 44: 5813-5821.

37. Brattain $M G$, Bratlain DE, Sarrif $\mathbb{E} M$, McRae $W$, Fine WD, Hawkins JG. Enhancement of growh of human colon tumor cell lines by feeder layers of mutine fibroblasts. JNCl 1982, 69: $767-771$.

38. Freeman AE. Hoflman RM. In vivo growth of human turnors in vitro. Proc. Natl. Acad. Sci. 1986, 83: 2694-2698.

39. Sharkey FE, Fogh JM, Hajdu SI, Fingerald PJ, Fogh J. Experience in surgical paühology with human tumor growth in the nude mouse. In: The nude mouse in experimental and clinical research. Fogh I, Grovanella BC (eds.) Acad. Press. New York, 1978: 187-214.

40. Merberman. Naural cell mediated cylotoxicity in nude mice. In the nude mice in experimental and clinical research. Fogh J, Giovanella BC (eds.) Acad. Press New York, 1978. 135160.

41. Areads JW, Schutte B, Wiggers T, Verstijnen CPHJ Blijham GH, Bosman FT. Comparison of phenotypic and genotypic reatures in primary laurgo bowel carcinoma and lympl node mochestases. Concer Res. in press.

42. Heppner GH. Tumor hetterogencity. Cancer Res. 1984, 44: 2259-2265.

43. Dexter DL. Heterogeneity in human colon cancer. It. Cancer invasion and metastasis: biologic and therapeutic aspects. Nicolson GL, Milas L. (eds.) Raven Press New York, 1984: 265. 279.

44. Fidler IJ, Hart IR. Biological diversity in melastatic neoplasia origins and implicaltons. Science 1982, 21\%: 998.1003.

45. Bractain MG, Marks ME, MoCombs $J$, Fintly $W$, Bratain DE, Characterization of human coloncarcinoma cell lines isolated from a single primary tumor. Br. J. Cancer 1683, 47: $373-381$. 
COLORECTAL (CANCER) ASSOCIATED ANTIGENS 


\section{INTRODUCTTON}

As was discussed already in chapter I, immunocytochemistry directed at detecting cellular characteristics that might be important for tumor classification, plays a central role in many studies concerning the pathology of human cancer. Especially with the introduction of the hybridoma technology for the production of monoclonal antibodies, enormous emphasis has been put on tumor analysis by monoclonal antibody immunostaining. Initial optimism led to expectations that the hybridoma technology would result in the discovery of tumor specific antigens. After ten years of application of monoclonal antibodies in tumor pathology it now seems that tumor specific antigens probably do not exist.

This chapter presents a number of detailed studies of monoclonal antibodies in the immunocytochemical assessment of colorectal cancer. In II.2 the production of a series of monoclonal antibodies against carcinoembryonic antigen (CEA) is presented. Special emphasis is put on the question whether or not tumor and/or organ specific variants of CEA exist. Moreover, the mechanism of crossreaction with crossreacting antigens, which has been one of the limiting factors in CEA as a tumor antigen is discussed.

In II-3 a study of the reactivity of the CA 19-9 antibody with nonneoplastic and neoplastic tissues is presented. The antigen, detected by this antibody is a monosialoganglioside, which was initially assumed to be highly tumor specific, especially for neoplasia of the gastrointestinal tract. Our study was mainly untertaken to investigate this presumed tumorspecificity.

In II-4 and II-5 the production of monoclonal antibodies against mucin associated antigens in the colon is discussed. Moreover, cxtensive immunocytochemical studies were performed to analyze possible tumor and/or organ specificity of the epitopes, recognized by the obtained monoclonal antibodies. In this part of the study, ample attention is paid to the use of normal differentiation antigens or developmental antigens in the study of the development of neoplasia. 


\section{CEA-SPECIFICITY OF CEA-REACTIVE MONOCLONAL ANTI- BODIES. IMMUNOCHEMICAL AND IMMUNOCYTOCHEMICAL STUDIES.}

\subsection{Introduction}

Since the isolation of carcinoembryonic antigen (CEA) from hepatic metastases of colonic adenocarcinoma in 1965 (1) this antigen has been considered as the prototype of a tumor antigen and as such has been used in the diagnosis and the monitoring of treatment of various types of cancer. More recently, CEA has also been explored as a target antigen for immunoscintigraphic procedures $(2,3)$. The value of CEA as a cancer marker, however, was contested when subsequent stuclies revealed the existence of several crossreacting antigens, which occur in normal tissues and share parts of their molecular structure with CEA. The lack of specificity of most conventional anti-CEA antisera has been largely attributed to reactivity with these crossreacting antigens. Over the years several glycoproteins sharing one (or more) antibody binding sites with CEA have been described (for review see 4, 30). These crossreacting substances have been found in normal tissues and in the serum of patients with malignant as well as non malignant diseases and include normal crossreacting antigens 1 and 2 (NCA 1 (5) and NCA 2 (6), meconium antigen (MA) (7), tumor-extracted-CEA related antigen (TEX) (8), normal fecal antigens 1 (NFA-1) (9) and 2 (NFA-2) (10), and biliary glycoprotein (BGP) (11). The molecular weight, carbohydrate content, lectin affinity pattern, and electrophoretic mobility of most of these antigens is known, but their exact molecular relationship to CEA has yet to be elucidated.

An additional problem in this context is that molecular variants of CEA, differing in molecular weight and electrophoretic mobility (12), have been reported. The molecular heterogeneity of CEA appears to be related to varying degrees of glycosylation (a postribosomal event). Some investigators have postulated that tumor specific CEA 
variants occur $(13,14,15)$. However, no convincing evidence of the existence of tumor or organ specific CEA epitopes has yet been provided.

Monoclonal antibodies (Mo Abs) may serve as precise immunological probes for the study of physicochemical qualities of the CEA molecules and, hence, information along this line may lead to a better understanding of the structural relationships between CEA and its crossreacting antigens. In recent years a variety of $C E A$ reactive $M o$ Abs has been generated (16-24). Some of these Mo Abs have been reported to recognize epitopes on the CEA molecule which are not shared with the known crossreacting antigens (20, 23, 24). Other Mo Abs have been claimed to identify specific molecular variants of CEA $(23,24)$.

Additional studies with CEA reactive Mo Abs will provide more detailed information on the immunochemical characteristics of the CEA molecule and its crossreacting antigens. In the present report we describe the immunochemical and immunocytochemical binding properties of four new anti-CEA Mo Abs.

\subsection{Materials and methods}

\section{Monoclonal antibodies (Mo Abs)}

The Mo Abs were obtained after immunization of Balb/c mice with either partially purified membrane preparations of colonic carcinoma tissue (Parlam 1) or with purified CEA (Parlam 4, 5, and 6). Spleen cells were fused with SP $2 / 0$ myeloma cells in a $2: 1$ ratio and after each fusion cells were plated in four 96 well microtiter plates containing 3,000 peritoneal macrophages per well as feeder layer. Developing clones were tested for antibody production in an ELISA on membrane preparations of colonic carcinomas. Antibody producing clones were selected on the basis of their immunocytochemical staining properties on frozen and paraffin sections of colonic carcinoma. Selected cultures were repeatedly cloned by limiting dilution until monoclonal. For the generation of large quantities of antibody, hybridoma cells were injected in Balb/c mice $\left(10^{-7}\right.$ cells per mouse) and ascites fluid was harvested.

Source and dilutions of antisera and conjugates

Polyclonal rabbit anti CEA antiserum (dilution 1:1000) peroxidase labeled rabbit anti mouse Ig (dilution 1:200), swine anti rabbit Ig 
(dilution 1:1000), rabbit peroxidase-antiperoxidase (PAP) complexes, (dilution 1:500) and peroxidase labeled swine anti rabbit Ig (dilution 1:200) were purchased from Dakopatts (Copenhagen, Denmark). All dilutions for immunohistochemical staining procedures were prepared in $0.05 \mathrm{M}$ Tris buffered saline (TBS) $\mathrm{pH} 7.6$ and for ELISA in phosphate buffered saline containing $0.05 \%$ Tween 20 (Sigma) (PBS-Tween).

\section{Tissue}

For extraction of CEA and related antigens by perchloric acid extraction, liver metastases of colonic carcinoma and normal splenic tissue were obtained at autopsy. For immunocytochemistry, routinely processed and paraffin embedded tissues from colonic adenocarcinomas, normal spleen, lung and liver were retrieved from the files of the department of pathology, Hospital St. Annadal Maastricht, The Netherlands.

\section{Perchloric acid (PCA) extraction}

Before extraction normal tissue components were dissected thoroughly from the cancer tissue. Colonic cancer and splenic tissue were cut into small pieces, diluted with 3 volumes of PBS, homogenized for $10 \mathrm{~min}$ in an omnimixer (Sorvall) at maximum speed and subsequently an equal volume of IN PCA was added dropwise under continuous stirring and the mixture was incubated for about $20 \mathrm{~min}$. The mixture was then centrifuged $(20,000 \mathrm{~g}$, for $30 \mathrm{~min})$ and subsequently the

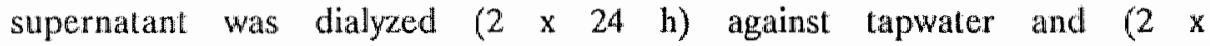
$24 \mathrm{~h})$ against distilled water. Insoluble particles were removed by centrifugation $(20,000 \mathrm{~g}, 20 \mathrm{~min})$. All preparative procedures were performed at $4^{\circ} \mathrm{C}$. The supernatant was filtered through a 0.45 $\mu \mathrm{m}$ filter, concentrated by pressure dialysis, lyophilized and stored at $-70^{\circ} \mathrm{C}$.

High pressure liquid chromatography (HPLC) purification of monoclonal antibodies

Monoclonal antibodies were concentrated from ascites fluid by $50 \%$ ammonium sulphate precipitation. After dialysis against 0.01 $M$ phosphate buffer ( $\mathrm{pH} 7$ ) the resolubilized immunoglobulins were purified by means of High Pressure Liquid Chromatography (HPLC) on a DEAE-ion exchange column (LKB). The column was loaded in $0.01 \mathrm{M}$ phosphate buffer $(\mathrm{pH} 7$ ) and eluted with a continuous 
$\mathrm{NaCl}$ gradient (0.0 to $0.5 \mathrm{M} \mathrm{NaCl}$ in $0.01 \mathrm{M}$ phosphate buffer). The antibodies eluted at $0.15 \mathrm{M} \mathrm{NaCl}$.

\section{Imnunocytachemistry}

Details of the immunoperoxidase staining procedure have been reported previously (33). Briefly, routinely processed $5 \mu \mathrm{m}$ paraffin sections were subjected to $0.1 \%$ trypsin in $0.1 \% \mathrm{CaCl}_{2}$ in distilled water (pH 7.8) for $25 \mathrm{~min}$. Endogenous peroxidase activity was blocked in $0.5 \% \mathrm{H}_{2} \mathrm{O}_{2}$ in methanol. For staining with monoclonal antibodies, slides were preincubated with $20 \%$ normal rabbit serum to prevent nonspecific binding. Subsequently the $\mathrm{Mo} A b s$ and the peroxidase labeled rabbit anti-mouse antiserum were applied. For staining with polyclonal antiserum, the slides were first incubated with $20 \%$ normal swine serum, followed by rabbit anti CEA antiserum and rabbit PAP complexes. Each incubation lasted 30 minutes at room temperature. Between each incubation sections were rinsed ( $3 \times{ }^{2} \quad 5$ min) with TBS. Peroxidase activity was visualized with $0.01 \% \quad \mathrm{H}_{2} \mathrm{O}_{2}$, and $0.5 \%$ diaminobenzidine in Tris- $\mathrm{HCl}$ buffer $(\mathrm{pH}$ 7.6) and the sections were counterstained with haematoxylin. Negative controls included replacement of specific antibodies with $\mathrm{Sp} 2 / 0$ supernatant or ascites for Mo $A b s$ and with non-immune serum for polyclonal antisera.

\section{Enzyme Linked Immuno Sorbent Assay (ELISA)}

ELISA's were performed on 96 well flatbottom polystyrene plates. Antigen was attached to the plates by overnight evaporation of aqueous antigen solutions at $37^{\circ} \mathrm{C}$. Prior to application of the primary antibody the plates were treated with $0.2 \%$ bovine serum albumin (Sigma) in PBS-Tween (PBS + $0.05 \%$ Tween 20, Signa) to prevent nonspecific binding. Mo $\mathrm{Ab}$ containing tissue culture supernatant, dilluted 1:4 in PBS-Tween supplemented with 10\% normal rabbit serum, was incubated $1 \mathrm{~h}$ at $37^{\circ} \mathrm{C}$. After washing with PBS-Tween plates were incubated with rabbit anti mouse peroxidase conjugate (dilution $1: 200,1 \mathrm{~h}$ after $37^{\circ} \mathrm{C}$ ). After a final wash with PBS-Tween, peroxidase activity was visualized with ortho-phenylene diamine. The reaction was stopped after 10 min with $2 \mathrm{~N}_{2} \mathrm{H}_{2} \mathrm{SO}_{4}$ and the extinction was measured at $492 \mathrm{~nm}$.

Sodium Dodecyl Sulphate Polyacrylamide Gel Electrophoresis (SDS$P A G E)$ followed by immunobloting

SDS-PAGE was performed according to the method of Laemmli (31). Forty $\mu \mathrm{g}$ of PCA extract of spleen and colon carcinoma was 
applied to the gel in phosphate buffer containing $1 \%$ Triton X100, $0.1 \%$ SDS, $7 \%$ mercaptoethanol and $0.1 \%$ bromophenol blue after boiling of this solution for 3 minutes.

Electrophoresed gels were transblotted to nitrocellulose sheets according to the method of Towbin et al. (32). Antigens transblotted to nitrocellulose sheets were visualized with an immunoperoxidase staining procedure. Sheets were preincubated with $0.2 \%$ bovine serum albumin in PBS-Tween. For the monoclonal antibodies sheets were incubated with undiluted tissue culture supernatant for 3 hours at $37^{\circ} \mathrm{C}$, washed 3 times with PBS-Tween, incubated with rabbit anti mouse peroxidase diluted 1:200 in PBS-Tween and 10\% normal rabbit serum for 1 hour at room temperature and washed 3 times in PBS-Tween. For the polyclonal antiserum sheets were incubated with rabbit anti CEA $\left(1: 100,2\right.$ hours at $\left.37^{\circ} \mathrm{C}\right)$, washed 3 times in PBS-Tween and incubated with peroxidase conjugated swine anti rabbit 1:200 diluted in PBS-Tween containing 10\% normal swine serum for 1 hour at room temperature and washed 3 times in PBS-Tween. As substrate diaminobenzidine was used.

\section{Blocking experiments}

To study epitope specificity of the Mo Abs, blocking experiments were performed in an ELISA and in immunocytochemical tests. To this end ammoniumsulphate precipitate (50\%) of ascites fluid was conjugated to horseradish peroxidase (Sigma grade IV) according to the method of Wilson and Nakane (34). For ELISA $30 \mathrm{ng}$ of purified CEA was attached to 96 wells plates as described before. Subsequently unconjugated Mo Ab (1:25) was applied (30 min. at $37^{\circ} \mathrm{C}$ ), followed by a 50 -fold lower concentration of one of the labeled Mo Abs. Washing procedures and determination of peroxidase activity were as described before. Blocking experiments were also performed on paraffin sections of colorectal carcinoma tissue. The processing of the sections was as described before. Unlabeled Mo Ab (1:25) was first applied ( 1 h, room temperature), followed by incubation with a 50-fold lower concentration of labeled Mo $\mathrm{Ab}$. The staining intensity of the immunoreactive sites was scored by two independent abservers. 


\subsection{Results}

\section{ELISA}

Figure 1 illustrates the binding of the Mo Abs to PCA extracts of colonic carcinoma tissue and spleen. Only Parlam 4 did not react with splenic PCA extract. The three other Mo Abs reacted with PCA extracts of colonic carcinoma and spleen. Parlam 1 showed less reactivity with splenic PCA extract than Parlam 5 and 6, which showed an approximately equal reactivity.

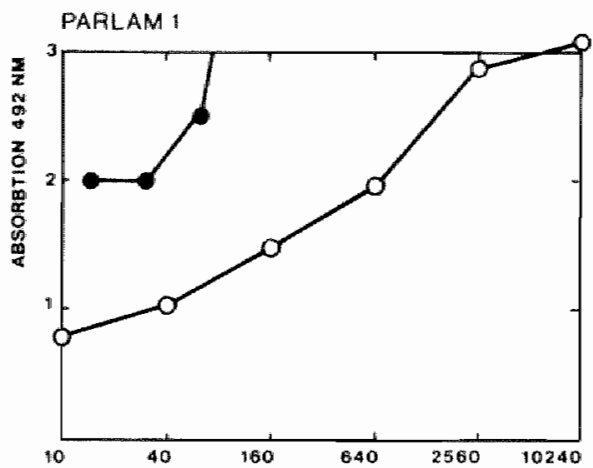

PARLAMI 4

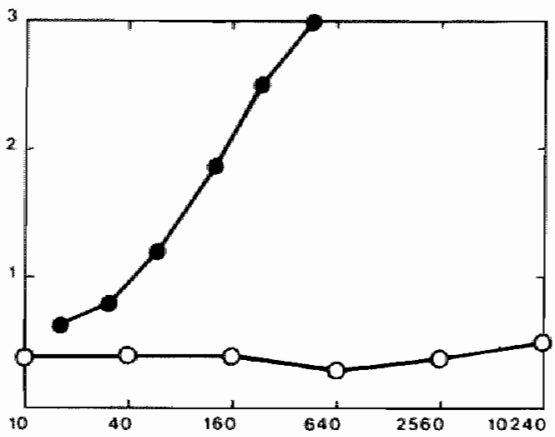

PARLAM 5

PARLAM 6
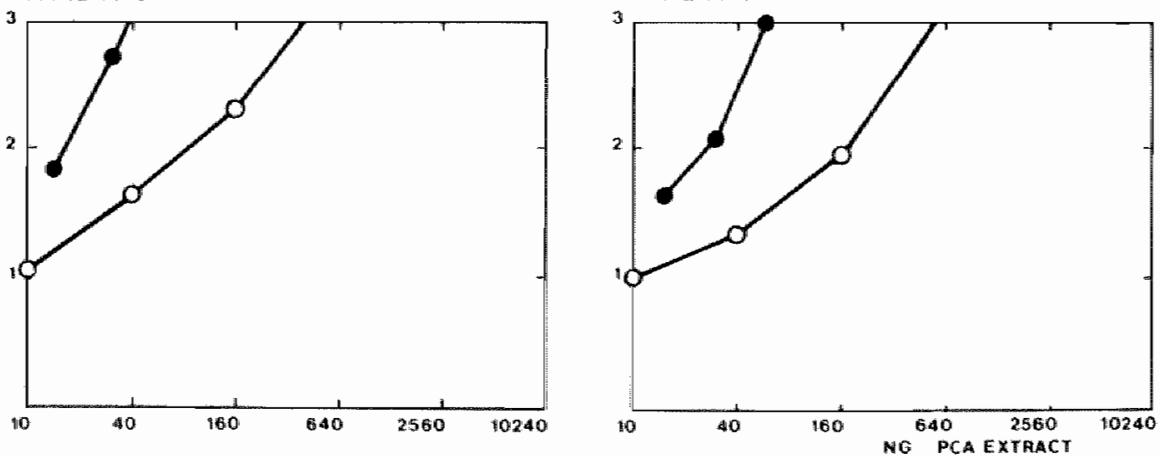

COHON CAACINONA

O NIOHMAL SPLEEN

Figure 1. ELISA with supernatants of Parlam 1, 4, 5 and 6 on different amounts of PCA extract of coloncarcinoma and normal spleen. 
SDS-PAGE followed by immunoblotting

Figure 2 shows the results of the immunoblot experiments obtained with the Mo Abs and polyclonal rabbit anti CEA on SDS-PAGE gels of PCA extracts of colonic carcinoma tissue and normal spleen. With PCA extracts of spleen polyclonal rabbit anti CEA, and Parlam 5 and 6 reacted moderately to strongly with antigens between 60 to $150 \mathrm{kD}$, whereas Parlam 1 demonstrated only weak reactivity and Parlam 4 did not show any binding at all.

On PCA extracts of colonic carcinoma tissue all antibodies displayed strong reactivity with antigens between 150 and $200 \mathrm{kD}$. Binding was also found with antigens between 60 and $150 \mathrm{kD}$ in a pattern comparable to that on PCA extracts of spleen: polyclonal rabbit anti CEA and Parlam 5 and 6 demonstrated a moderate to strong reactivity, Parlam 1 a weaker reactivity and Parlam 4 no reactivity at all to antigens in this molecular weight range.

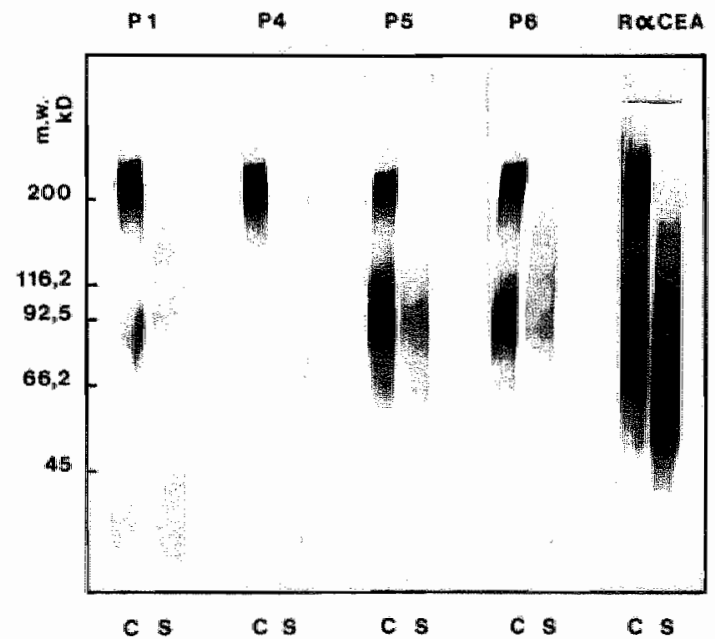

Figure 2. SDS-PAGE of PCA extracts of colon carcinoma (c) and normal spleen (s) followed by immunoblotting with Parlam (p) $1,4,5$ and 6 and polyclonal rabbit - anti CEA (Ra CEA) antisenum.

Immunocytochemistry

The results of the immunocytochemical tests on various tissue sections are compiled in Table 1. All Mo Abs reacted with colonic carcinoma cells (Figure 3) in an apical staining pattern over a wide range of concentrations. Staining of the apical cell membrane of normal colonic mucosa was also noted, but this generally disappeared when the Mo Abs were used in low concentrations. All Mo Abs reacted with granulocytes in sections of colonic carcinoma as well as spleen but with varying intensity at different concentrations. Parlam 5 
and Parlam 6 reacted with granulocytes even at high dilutions, whereas Parlam 4 showed only faint reactivity when applied in high concentration: similar observations were made on sections of lung and liver.

Table I. Immunoperoxidase staining of Parlam $1,4,5$ and 6 on colonic carcinoma tissue, spleen, lung and liver tissue.

\begin{tabular}{|c|c|c|c|c|c|}
\hline Organ & Dilution* & & activ & rlam & \\
\hline & MAB & 1 & 4 & 5 & $\overline{6}$ \\
\hline $\begin{array}{l}\text { Colon } \\
\text { Carcinoma }\end{array}$ & $\begin{array}{l}1: 10^{2} \\
1: 10^{3} \\
1: 10^{4}\end{array}$ & $\begin{array}{r}++4 \\
+4 \\
+4\end{array}$ & $\begin{array}{r}+4+ \\
+4+ \\
+4\end{array}$ & $\begin{array}{r}+++ \\
+++ \\
++\end{array}$ & $\begin{array}{r}+++ \\
+++ \\
++\end{array}$ \\
\hline Spleen & $\begin{array}{l}1: 10^{2} \\
1: 10^{3} \\
1: 10^{4}\end{array}$ & $\begin{array}{r}++ \\
+ \\
-\end{array}$ & $\begin{array}{l} \pm \\
-\end{array}$ & $\begin{array}{r}+++ \\
+++ \\
++\end{array}$ & $\begin{array}{r}+++ \\
+++ \\
+\end{array}$ \\
\hline Lung & $\begin{array}{l}1: 10^{2} \\
1: 10^{3} \\
1: 10^{4}\end{array}$ & $\begin{array}{l} \pm \\
\pm\end{array}$ & $\begin{array}{l}+ \\
- \\
-\end{array}$ & $\begin{array}{r}+++ \\
+++ \\
++\end{array}$ & $\begin{array}{r}+++ \\
+++ \\
++\end{array}$ \\
\hline Liver & $\begin{array}{l}1: 10^{2} \\
1: 10^{3} \\
1: 10^{4}\end{array}$ & $\begin{array}{l}+ \\
-\end{array}$ & $\begin{array}{l}+ \\
\pm\end{array}$ & $\begin{array}{r}++t \\
++ \\
\pm\end{array}$ & $\begin{array}{l}\text { ND } \\
++++ \\
+++ \\
r+4\end{array}$ \\
\hline
\end{tabular}

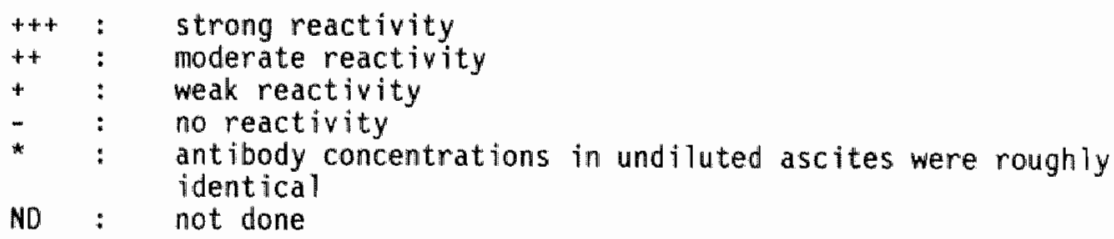

All Mo Abs reacted with pneumocytes type 1 and alveolar macrophages in the lung and bile canaliculi in the liver (Figure 4). Parlam 5 and Parlam 6 did so, even at low concentrations, whereas Parlam 1 and most notably Parlam 4 reacted only when applied in very high concentrations. Table II illustrates this difference. 


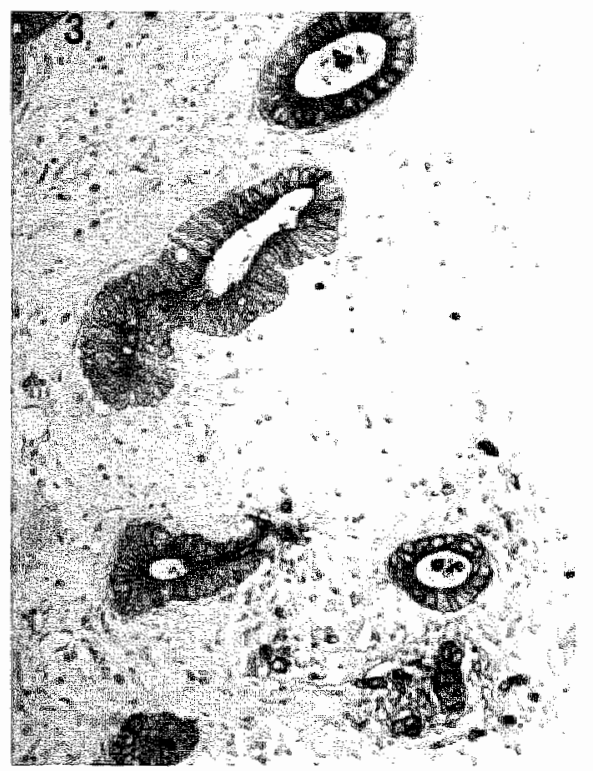

Figure 3. Inmunoperoxidase staining of Parlam 4 on colon carcinoma $(x 60)$.

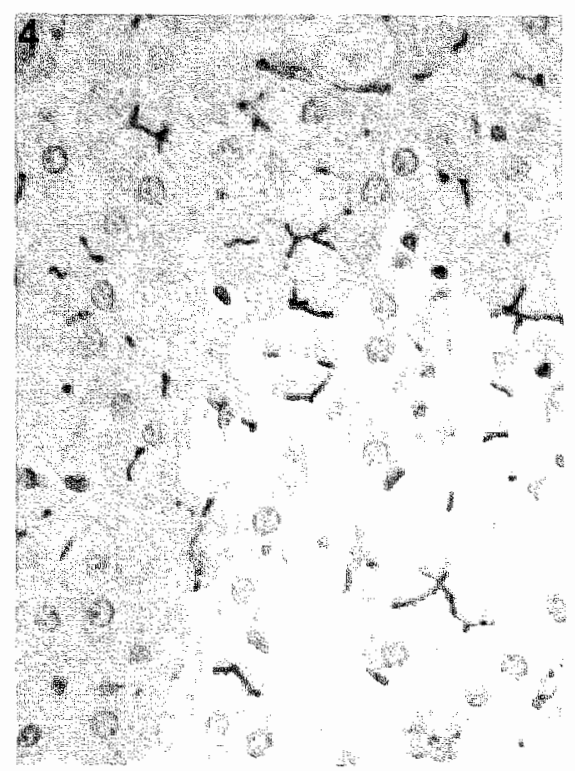

Figure 4. Immunoperoxidase staining of Parlam 6 on normal liver tissue $(x 400)$.

Table II. Lowest concentration of the MAB's needed to give reactivity with respectively granulocyles and colon carcinoma tissue in immunocylochemistry and the concentration ratio granulocytes/colon carcinoma.

\begin{tabular}{|c|c|c|c|}
\hline Parlam & \multicolumn{2}{|c|}{$\begin{array}{c}\text { Concentration (mo } / / m 1) \\
\text { to qive reactivity with }\end{array}$} & $\begin{array}{c}\text { Ratio } \\
\text { granulocytes/ } \\
\text { colon carcinoma }\end{array}$ \\
\cline { 2 - 3 } & Granulocytes & Carcinama & \\
\hline 1 & 2 & 0.1 & 20 \\
4 & 10 & 0.1 & 100 \\
5 & 0.1 & 0.1 & 1 \\
6 & 0.1 & 0.1 & 1 \\
\hline
\end{tabular}


To obtain any reactivity with granulocytes, Parlam 4 had to be applied in a 100 fold higher concentration than was necessary to obtain reactivity with colonic cancer tissue. For Parlam 1 a 20 fold higher dilution was necessary to stain granulocytes and for Parlam 5 and 6 there was no difference at all. This indicates that Parlam 4 and to a lesser extent also Parlam 1 have a much higher affinity for CEA than for the crossreacting antigens in granulocytes.

\section{Blocking experiments}

The results of the ELISA and immunocytochemical blocking experiments are shown in Tables III and IV.

Table III. Blocking in an ELISA from peroxidase conjugated Mo Abs to CEA by preincubation with unconjugated Mo Abs. Table shows percentage of reactivity after blocking compared to normal binding.

\begin{tabular}{l|c|cccc}
\hline \multicolumn{2}{l}{} & \multicolumn{4}{c}{ Unconjugated Par lam } \\
\hline \multicolumn{1}{l|}{} & 1 & 4 & 5 & 6 \\
\hline $\begin{array}{l}\text { HRP } \\
\text { Parlagated }\end{array}$ & 1 & 16 & 78 & 16 & 42 \\
& 4 & 28 & 17 & 73 & 62 \\
& 5 & 25 & 99 & 20 & 67 \\
& 6 & 48 & 99 & 44 & 28 \\
\hline
\end{tabular}

The results in both test systems were largely confirmatory. Binding of peroxidase conjugated $\mathrm{Mo} \mathrm{Ab}$ was always blocked by the homologous unlabeled Mo $\mathrm{Ab}$. Parlam 1 and 5 also blocked each other, indicating that they are directed against a closely related epitope. Other combinations of labeled and unlabeled Mo Abs showed more complex results. Occasionally the results of both tests showed discrepancies, which may be related to differences in physicochemical properties between CEA in PCA extracts and CEA in routinely processed tissue sections. 
Table $I V . \quad$ Blocking experiments in immunocytochemistry. Intensity of staining after competition of conjugated Mo Abs with a 50 fold excess of Ig of unconjugated Mo Abs on various tissue sections.

\begin{tabular}{llcccc}
\hline Colon carcinoma & & \multicolumn{4}{c}{ Blocker Parlam } \\
\cline { 3 - 6 } & & 1 & 4 & 5 & 6 \\
\hline HRP & 1 & - & ++ & - & + \\
Conjugated & 4 & + & - & ++ & ++ \\
Parlam & 5 & + & ++ & - & ++ \\
& 6 & ++ & ++ & ++ & - \\
\hline
\end{tabular}

Normal colon

Blocker Parlam

\begin{tabular}{ll|cccc}
\cline { 3 - 6 } \multicolumn{1}{c}{} & & 1 & 4 & 5 & 6 \\
\hline HRP & 1 & - & + & + & - \\
Conjugated & 4 & - & - & + & - \\
Parlain & 5 & + & + & - & - \\
& 6 & ++ & + & - & - \\
\hline
\end{tabular}

Granulocytes

Blocker Parlam

\begin{tabular}{ll|cccc}
\cline { 3 - 6 } & & 1 & 4 & 5 & 6 \\
\hline HRP & 1 & - & - & - & - \\
Conjugated & 4 & - & - & - & - \\
Parlam & 5 & + & ++ & + & - \\
& 6 & ++ & ++ & - & - \\
\hline
\end{tabular}

+ - Clear reactivity

* = Weak reactivity

- = No reactivity

\subsection{Discussion}

CEA is a complex glycoprotein consisting of a single polypeptide chain of 829 amino acid residues with a variable number of relatively short oligosaccharide chains attached to approximately 1 out of every 10 amino acid residues. Analysis of the antigenic structure 
of CEA has been hampered by the heterogeneity of the CEA molecule, which may be due to variations in (the degree of) glycosylation and to the existence of a number of glycoproteins such as NCA1, NCA-2, TEX, MA, NFA, and NFA-2, which to a variable extent crossreact with the anti-CEA antibodies.

The advent of monoclonal antibodies (25) raised the expectation that CEA-specific antigenic determinants could be recognized. A considerable number of monoclonal antibodies has been generated and the CEA reactive Mo Abs can be divided into three categories: a) Mo Abs reacting with one or more of the known crossreacting glycoproteins (16-18, 20-24, 26); (b) Mo Abs detecting a purportedly CEA specific epitope $(20,21,23,24,26)$; and (c) Mo Abs recognizing a molecular variant of CEA $(23,24)$. Each of these categories will be briefly reviewed.

Most of the CEA-reactive Mo Abs reported so far appear to react also with one or more of the known crossreacting antigens, and many appear to do so with roughly equal affinity (16-18, 20-24, 26.29). Others, however, bind to cross reacting antigens with much less affinily and these are referred to as CEA specific. For example, Heding et al. (21) described CEA-specific Mo Abs weakly crossreactive with NCA-II.

The evaluation of the CEA specificity of CEA-reactive Mo Abs has been confounded by the variability of the results in different test systems. Wagener et al. $(22,27)$ described five Mo Abs which in fluid phase immunoassays appeared to be CEA specific. By immunocytochemistry, however, all Mo Abs revealed at least weak reactivity with granulocytes (NCA-1) or bile canaliculi (BGP) in the liver or both. Haskell et al. (28) analyzed six Mo Abs with roughly equal affinity to CEA. Three of these did not show binding to crossreacting antigens in fluid phase immunoassay whereas on tissue antigens sections these Mo Abs revealed at least traces of reactivity with granulocytes. It therefore appears that immunocytochemical testing on tissue sections is either more sensitive or allows the detection of epitopes which escape detection in fluid phase immuno assays on purified CEA.

CEA-reactive Mo Abs have been generated by Kuroki et al (24) which were claimed to recognize allotypic determinants on the CEA molecule. They have generated three CEA-specific Mo Abs which reacted with only 13 out of 50 sera from patients with elevated CEA levels. These Mo Abs, however, were not tested by immunocytochemistry. Primus et al. (29) described a low affinity CEA reactive Mo Ab 
which by immunocytochemistry reacted with a subgroup of colonic carcinomas and did not cross-react with granulocytes.

The CEA reactive Mo Abs described in the present report showed approximately equal reactivity to CEA in terms of binding characteristics by immunocytochemistry, by ELISA, and by immunoblotting. However, different patterns of reactivity were found with crossreacting antigens. Parlam 4 failed to react with PCA extracts of splenic tissue, but immunocytochemistry showed a slight reactivity with granulocytes (which can be ascribed to NCA-1) and also with bile canaliculi in the liver (BGP). The difference in reactivity with different test systems may be caused by the differences in the processing of the antigens. For the immunochemical tests PCA extracts were used; whereas formaldehyde fixation and paraffin embedding were applied for immunocytochemistry.

In contrast, Parlam 1 reacted moderately and Parlam 5 and 6 strongly with granulocytes by immunocytochemistry and with PCA-extracts of splenic tissue in ELISA and immunoblotting, suggesting moderate to strong crossreactivity with NCA-1. Parlam 4 did not inhibit binding of Parlam 1,5 or 6 by ELISA nor by immunocytochemistry. This Mo Ab therefore appears to detect an epitope fairly unique for CEA. Parlam 1 and 5 showed roughly equal affinity for CEA but differed in their affinity for NCA-1, although in blocking experiments they inhibited each others binding to both antigens almost completely. Similar findings were reported by Primus et al. (23). Their monoclonal anlibodies NP-1 and NP-2 inhibited each others binding with CEA, while NP-1 did bind to NCA but NP-2 did not. Parlam 5 and 6 , linally, show similar patterns of reactivity in all test systems but inhibition experiments suggest that they react with different epitopes.

Taken together, the data from the literature as well as our own observations indicate that the application of CEA-reactive Mo Abs so far has generated less progress than expected in the immunological characterization of CEA and crossreacting antigens. In addition, Mo Abs unequivocally specific for CEA, in all test systems have as yet not been described. In this context we contend that the idea of one Mo Ab specific for only one particular epitope is too simplistic. First, it is possible that anti-CEA Mo Abs, in addition to reacting with their corresponding epitope may also bind with lower affinity to chemically different but structurally simillar epitopes, occurring on the CEA molecule itself or the crossreacting antigens (epitope crossreactivity, Figure 5). 
Second, it is possible that in the native CEA molecule an epitope is formed by a complex of different molecular domains, which in the denaturated molecule reside in separate regions. These domains, which would occur on CEA as well as crossreacting antigens may retain the capacity to bind the antibody though with less affinity (partial epitope sharing, Figure 6).
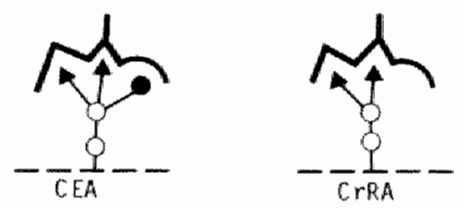

Figure 5. Epitope cross-reactivity. Binding of a Mo $A b$ to $C E A$ and to structurally related crossreacting antigen (CrRA).

- - : polypeptide chains

๑ : carbohydrate side chains
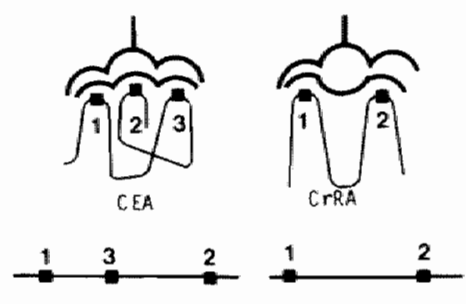

Figure 6. Partial epitope sharing. $A$ Mo $A b$ binds with lower affinity to an epitope on cross-reacting antigens (CrRA) that possesses less domains than are present on the CEA molecule.

We propose that the low affinity cross-reactivities of CEA reactive Mo Abs are caused by epilope-crossreactivily and/or by partial epitope sharing. This apparent complexity of the Mo Ab epitope relationship reduces the chances to obtain a truly CEA-specific Mo Ab.

However, a Mo $\mathrm{Ab}$ reacting with a fairly unique epitope on CEA and with only very low affinity for a restricted number of other epitopes or epitope domains on the crossreacting antigens may fulfill the requirements for in vitro and in vivo diagnostic use. Our Mo Ab Parlam 4 appears to be such an antibody. 


\section{References}

1. Gold $\mathrm{P}$ and Freedman SO: Specific carcimoembryonic antigens of the human digestive system. J. Exp. Med. 1965, 122: $467-481$.

2. Mach JP, Carrel S, Forni $M$, Ritschard $J$, Donath $A$, and Alberto $P$ : Tumor locatization of radiolabeled antibodies against carcinoembryonic antigen in pathents wilth carcinomi. N. Engl, J. Med. $1980,303: 5-10$.

3. Goldenberg DM, Kim EE, Dehard FH, Biennett $S$, and Primus FJ: Radioimmunodetection of cancer with radionctive antibodies to carcinoembryonic antigen. Cancer Res. 1980, 40: $2984-2992$.

4. Rogers GT: Carcinoembryonic antigens and related glycoproteins. Molecular aspects and specificity. Biochin. Biophys. Acla 1983, 695: 227.279.

5. Von Kleist $S$, Chavanel $G$, and Burtin $P$ : Identification of an antigen from normal human tissue that crossreacts with the carcinoembryonic antigen. Proc. Natl. Acad. Sci. 1972, 69:2492-2494.

6. Burtin $P$, Chavanel $G$, and Hirsch Marie $A$ : Characterization of a second normal antigen that crossreacts with CEA. J. Imminol. 1973, 111: $1926-1928$.

7. Primus FJ, Freeman JW, and Goldenberg DM: Immunological heterogeneity of cancinoembryonic. antigen: Purification from meconium of an antigen related to carcinoembryonic antigen. Cancer Res. 1983, 43: 679-685.

8. Kessler MJ, Shively RW, Pritchard GD, and Todd LW" Isolation, immunological characterization and structural studies of a tumor antigen * related carcinoembryonic antigen. Cancen Res. 1978, 38: 1041-1048.

9. Kuroki $M$, Shinoda $T$, Takayasa $T$, Koya $Y$, and Matsuoka $Y$ : Immunological characterization and structural studies of normal fecal antigen-1 related to carcinombryonic antigen. Mol. lonmunol. 1982, 19: 399-406.

10. Kuroki $M$, Koga $Y$, and Matsuoka $Y$ : Purification and characterization of carcinoembryonic antigen - related antigens in normal adult feces. Cancer Res. 1981, 41: 713-720.

11. Sveaberg T: Carcinoembryonic anligen-like substances of human bile. Isolation and partial characterization. Int. J. Cancer 1976,17 ; 588-596.

12. Coligan JE, Lautenschleger JT, Egan ML, and Todd CW: Isolation and characterization of carcinoembryonic antigen. Immunochen. 1972, 9: 377-386.

13. Chism GE, Warner $\mathrm{NL}_{x}$ Wells JV, Crewtler $P$, Hunt $G$, Marchallonis JJ, and Fudenberg HH Evidence for common and distinct determinants of colon carcinoembryonic antigen $n_{y}$ colon carcinoma antigen III and molecules with carcinoembryonic antigen activity isolated from breast and ovarian cancers. Cancer Res. 1977, 37: 3100-3108.

14. Santen RJ, Collette $J$, and Franchimont $P$ : Partial purification of carcinotmbryonic reactive antigen from breast neopiasms using lectin and antibody affinity chromatography. Cancer Res. 1980, 40: 1181-1188.

15. Harvey $\mathrm{SR}$, Girota $\mathrm{RN}$, Nemoto $\mathrm{T}$, Ciani $F$, and Chu TM: Immunochemical sludie:s ory carcinoembryonic-antigen teactive glycoproteins from carcinomas of the colon and breast separated on concanavalin A affinity chromatography. Cancer Res. 1976, 36: 3486-3499.

16. Accolla RS, Carrel $S$, and Mach JP: Monoclonal antibodies specific for carcinombryonic antigen and produced by two hybrid cell lines. Proc. Nall. Acad. Sci. 1980, 77: 563.560.

17. Rogers GT, Rawins GA, and Bagshawe KD: Somalic-cell bybrids producing antibodies angainst CEA. Br. J. Cancer 1981, 43: 114.

18. Kupchil HZ, Kurowski WR, Hurrell JGR, Zamcheck $N$, and Black PH: Monoclonal antibodies to carcinoembryonic antigen produced by somatic cell fussion. Cancer Res. 1981, 41: 3306 . 3310 .

19. Lingnen $J$, Wahlstrm $T$, Bang $B$, Hurme $M$, and Mikelig $O$; Immunoperoxidase staining of carcinoembryonic antigen with monodonal antibodies in adenocarcinoma of the collom. Histochemistry 1982, 74: $223-227$.

20. Grunert $F$, Wank $K$, Luckenbach $G A$, and Von Kleist $S$ : Monoclonal antibordies against CEA. Comparison of the immunoprecipitates by fingerprint analysis. Oncodevelopmental Biology and Medicine 1982, 3: 191-200.

21. Hedin $A$, Hammerstrm $G$, and Larson $A$ : Specificities and binding properties of eight monoctonal antibodies aganst carcinoembryonic antigen. Mol. Immunol. 1982, 19: 1641. $164 b$.

22. Wagener $C$, Joy Yang $\mathrm{YH}$, Crawford $F G$, and Shively JE: Monoclonal antibodies for carcinocmbryonic antigen and related antigens as a model system: a systematic approach for 
the determination of epilope spexifictites of monoclonal antibodies. I. Immunol. 1983, 130: $2308-2315$.

23. Primul FJ, Newell $K D$, Blue $A_{\text {, and }}$ Goldenberg DM: Immunological heterogeneity of carcinoembryonic antigen: Amtigenic determinants on carcinoembryonic antigen distinguished by monoclomal antibodies. Cancer Res. 1983, 43: 686-692.

24. Kurok Ma, Kurokj Mo, Koga $Y$, and Matsuolka $Y$ : Monoclonal anibodies to carcinoembryonic antigen: A systematic analysis of antibody specificities by using related normal antiggns and evidence for allowypic determinants on carcinoembryonic antigen. J. Immunol 1984, 133: 20902097 .

25. Kunler $G$, and Mistein $C_{\text {: }}$ Continuous cultures of fused cells secreting antibodies of predefined specificity. Nature $1975,256: 495-497$.

26. Bischegger $F$, Schrever $M$, Carrel $S$, and Mach JP: Monoclonal antibodies identify a CEA crostreacting antigen of $95 \mathrm{kD}$ (NCA-95) distinct in antigenicity and tissue distribution: from the previously described NCA of $55 \mathrm{kD}$. Int. J. Cancer 1984, 33: 643-649.

27. Wagener C, Clark BR, Rickard KJ, and Shively $\mathbb{E E}$. Monoctonal antibodies for carcinoembryonic antigen and related antigens as a model system: determination of affinities and specificities of monoclonal antibordies using biotin-labeled antibodies and avidin as precipilating agent in solition phase immunoassay. Jl. Immunol 1983, 130: $2302 \cdot 2307$.

28. Haskell $C M$, Buchegger $F$, Schreyer $M$, Carrel $S$, and Mach JP: Monoclonal antibodies. to. carcinocmbryonic antigen: ionic strength as a factor in the sellection of antibodies. for immunoscintigraplyy. Cancer Res. 1983, 43: 3857-3864.

29. Primus $\mathrm{FJ}$, Kulus WJ, and Goldenberg DM: Immunological heterogeneity of carcinoembryonic: antigen determinants in colonic tumors with monoctonal antibodies. Cancer 1983, 43: 693701.

30. Rogers GT: Heterogeneity of carcinoembryonic antigen. Implications on its role as a tumor marker substance. Biochim. Biophys. Acta 1976, 458: 3554373.

31. Laemmli UK: Cleavage of structural proteins during the assembly of the head bacteriophage T4. Nature 1970, 227: 680-685.

32. Towbin H, Staehelin $T$, and Gordin J: Electrophoretic transfer of proteins from polyacrylamide gels to nitrocellulose sheets: procedure and some applications. Proc. Natl. Acad. Sicv. (USA) 1970, 76: $4350-4354$

33. Arends JW, Verstijnen C, Bosman FT, Hilgers $J_{*}$ and Steplewsky $Z$; Distribution of monoclonal antibodydefined monosialoganglioside in normal and cancerous human lissues: an immunoperoxidase study. Hybridoma 1983, 2: $219-229$.

34. Wilson ME and Nakane PK: Recent developments in periodate method of conjugating horseradish peroxidase (HRPO) to antibodies. In: Immunofluorescence and related staining techniques. (Knapp W. el al., eds.) Amsterdam, Elsevier / North Holland Biochemical Press, 1978, p. 215. 


\section{DISTRIBUTION OF MONOCLONAL ANTIBODY-DEFINED MONOSIALOGANGLIOSIDE IN NORMAL AND CANCEROUS HUMAN TISSUES: AN IMMUNOPEROXIDASE STUDY}

\subsection{Introduction}

Monoclonal antibodies against colon carcinoma were first reported by Koprowski et al (1) in 1979. The binding to colon carcinoma cells of one of these monoclonal antibodies was inhibited by sera from patients with adenocarcinoma of the colon, stomach, and pancreas, but not by sera from patients with other bowel diseases or from healthy individuals (2). Furthermore, the antibody did not react with carcinoma cell lines other than colorectal (1). The target antigen was subsequently defined as a monosialoganglioside (3), which was demonstrable in colorectal carcinoma tissue and meconium only. Because the antigen appeared to retain sufficient immunoreactivity after routine fixation and tissue processing procedures, it became possible to determine its distribution and precise tissue localization in different organs by means of an immunoperoxidase technique.

We report here the results of the immunoreactivity assays of this monoclonal antibody-defined monosialoganglioside in adenocarcinomas and in fetal and adult glandular tissues. The antigen is not restricted to oncofetal tissues, as it can be detected in normal adult epithelia of gall bladder, endocervix, pancreas, salivary glands, and colon. Most colonic adenocarcinomas and other adenocarcinomas of the endometrium, pancreas and stomach demonstrate the antigen. Staining of normal colonic mucosa was restricted to areas adjacent to tumor tissue.

\subsection{Materials and methods}

\section{Monoclonal antibody}

The hybridoma 1116NS19-9 (19-9), which secretes antibody (IgG1; ref. 4) against the SW1116 colon carcinoma cell line, was established 
after fusion of immune splenocytes with the 653 variant of P3X63Ag8 myeloma cells.

\section{Tissues}

The immunoreactivity of the 19-9 antibody was tested on paraffin sections, fixed in $10 \%$ neutral-buffered formalin, of the following human tissues: a panel of adenocarcinomas (Table 1), a total of 17 fetal intestinal mucosa from 12-40 week fetuses (kindly provided by Dr. J. Huber, Professor of pediatric Pathology, State University, Utrecht, The Netherlands); and normal adult glandular and mucosal epithelia (Table 2).

\section{Immunocytochemistry}

Initially, to determine the influence of routine tissue processing procedures on the immunoreactivity of the antigen, the staining patterns of frozen sections postfixed in acetone $\left(10\right.$ min at $\left.4^{\circ} \mathrm{C}\right)$ and of formalin-fixed and paraffin-embedded tissue sections of the same tumor were compared. Paraffin-embedded tissue sections $(5 \mu \mathrm{m})$ were then deparaflinized, relyydrated, and blocked for endogenous peroxidase activity by incubation in a $0.5 \%$ solution of hydrogen peroxide in methanol. After incubation in a $0.1 \%$ trypsin (Sigma Chemical Company) solution in $0.1 \% \mathrm{CaCl}_{2}$ (pH 7.8) for $25 \mathrm{~min}$ at $37^{\circ} \mathrm{C}$, sections were incubated with normal rabbit serum (1:5) for $10 \mathrm{~min}$ and then with 19-9 monoclonal antibody (1:256) for 30 min. The optimal antibody dilution for paraffin sections was found to be 1:256; the antibody was used undiluted for frozen sections. Sections were then exposed to peroxidase-labeled rabbit anti-mouse Ig (DAKO, code no. P161) (1:50) for $30 \mathrm{~min}$. All dilutions were made with $2.5 \%$ normal human serum in Tris buffer ( $\mathrm{pH} 7.6)$. Each step was followed by washing in Tris buffer (three changes in $5 \mathrm{~min}$ ). Finally the sections were developed with diaminobenzidine and counterstained with hematoxylin.

\subsection{Results}

The distribution of the monoclonal antibody-defined monosialoganglioside did not appear to be different on mildly lixed frozen as compared with formalin-fixed, paraffin-embedded sections of the same tissues, when the antibody was applied undiluted on the former and used after trypsinization on the latter. When diluted monoclonal 
antibody was applied on frozen sections or undiluted antibody was used on nontrypsinized paraffin sections, no consistent pattern of staining was obtained.

\section{Adenocarcinomas}

Thirty-eight of $54(70 \%)$ of colorectal adenocarcinomas of the colorectum an eight of 11 (73\%) endometrial adenocarcinomas reacted with 19-9 antibody. Seven of $13(54 \%)$ gastric and two of three pancreatic adenocarcinomas also reacted with antibody 19-9 (Table 1).

Table I. Distribution of $19-9$ antibody binding to adenocarcinomas.

\begin{tabular}{lccl}
\hline & $\begin{array}{l}\text { No. of total no of } \\
\text { positive cases tested } \\
\text { cases } \\
\text { positive }\end{array}$ & $\%$ Pattern of activity \\
\hline $\begin{array}{l}\text { Colorectum } \\
\text { Stomach }\end{array}$ & $7 / 13$ & $70 \begin{array}{l}\text { Apical cell parts and lu- } \\
\text { minal debris predominantly } \\
\text { in a focal pattern }\end{array}$ \\
Pancreas & $2 / 3$ & $54 \begin{array}{l}\text { Apical cell parts, cyto } \\
\text { plasm of signet ring cells } \\
\text { and mucus }\end{array}$ \\
Gall bladder & $1 / 2$ & 66 & $\begin{array}{l}\text { Luminal cell surface or } \\
\text { cytoplasm of tumor cells }\end{array}$ \\
Endometrium & $8 / 11$ & 50 & 73 cytoplasm of tumor cells \\
Kidney & $0 / 2$ & 0 & - \\
Prostate & $0 / 2$ & 0 & - \\
Breast & $1 / 10$ & 10 & -
\end{tabular}

One of two gall bladder carcinomas and only one of 10 breast carcinomas were reactive. The two carcinomas of prostate and two of kidney tested were negative for the presence of the antigen. The majority of adenocarcinomas of the colorectum (fig. 1) and endometrium (fig. 2a) reacted with the 19-9 antibody, predominantly as a focal 


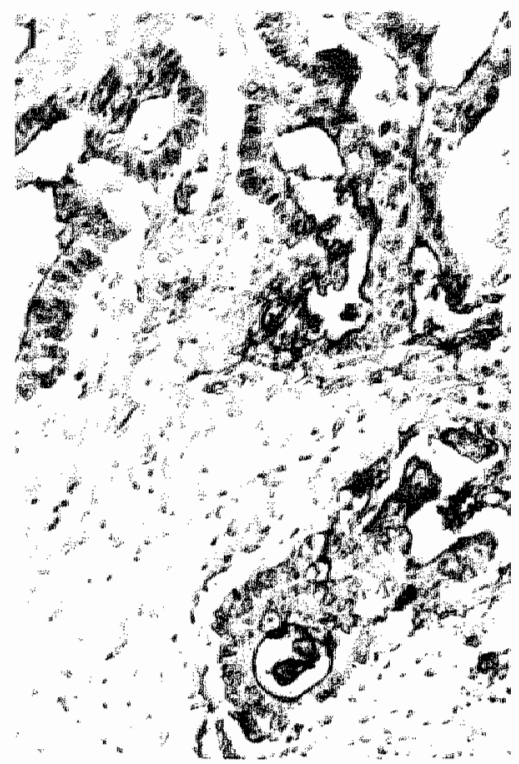

Figure 1. Colonic adenocarcinoma. A reaction praduct at the luminal cell border (arrow. x60)

Figure 2. Adenocarcinoma of endometrium (A) and pancreas (B). (x100)

24

$$
6 \text { to }
$$

$p$

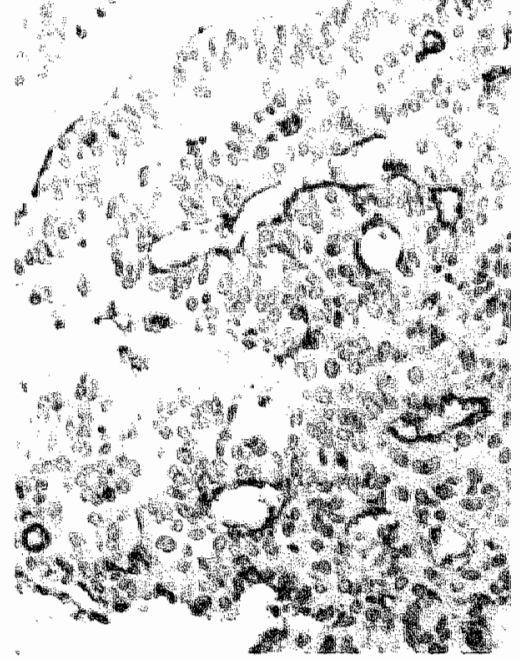

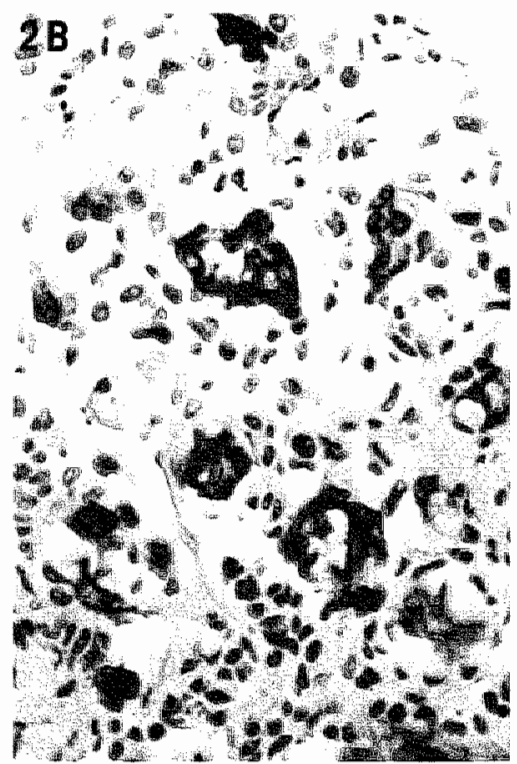


staining of apical cell borders and secretion products in glandular tumor formations. In some tumors, cytoplasmic dots were occasionally observed. Adenocarcinomas of the pancreas (fig. 2b), stomach (fig. 3a), and gall bladder, as well as one case of breast carcinoma (fig. 3b) showed a focal reaction product in glandular formations.
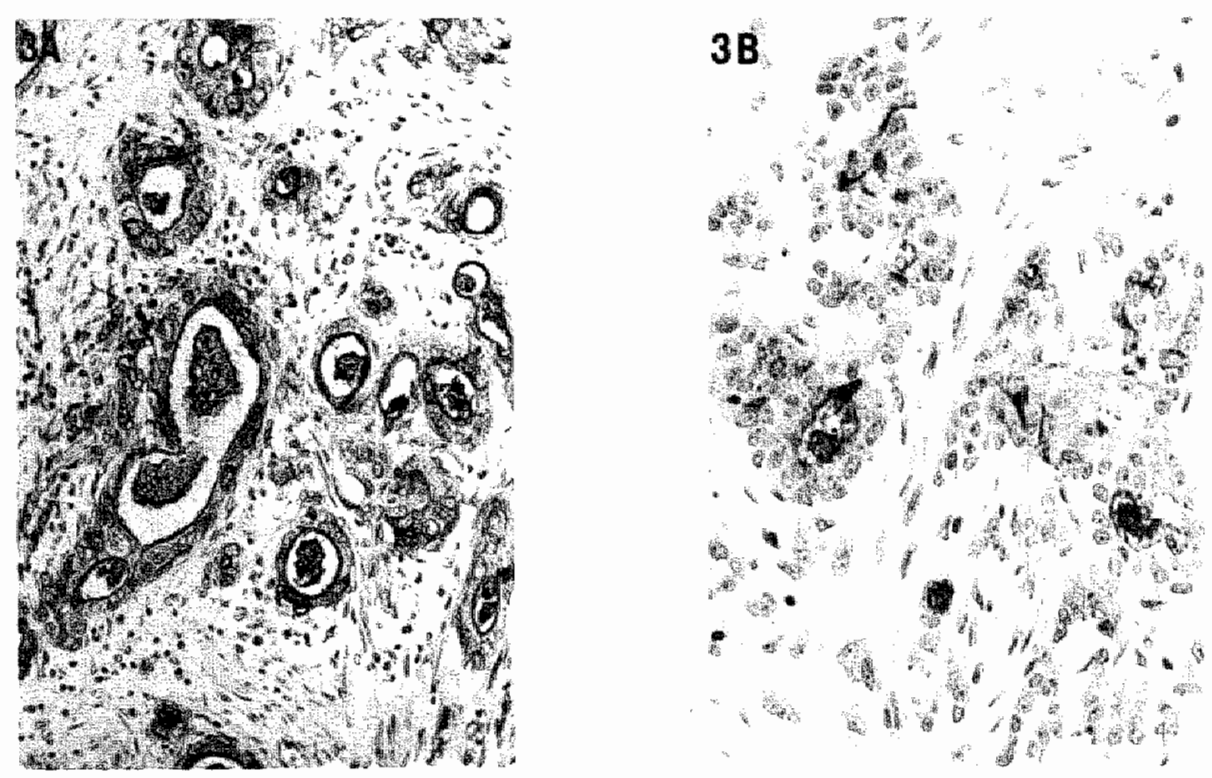

Figure 3. Adenocarcinoma of stomach $(A)$ and breast $(B)$. (x60 and $x 100)$.

Adult giandular and mucosal epithelia

The results of the immunoperoxidase assay for the detection of the antibody 19-9 defined antigen in adult glandular and mucosal epithelia are summarized in Table 2. Twelve of $20(60 \%)$ colorectal mucosa and five of $10(50 \%)$ gastric mucosa showed positive staining with the 19-9 antibody only in areas ajacent to the tumor. Endocervical mucosa and salivary gland ductal epithelium tested were also positive, and three of four pancreas ductal epithelium and six of seven gall bladder epithelium also showed staining. Normal kidney, prostate, an breast were all negative for antigen expression. Large intestinal mucosa showed no staining. Immunoreactivity detected in normal epithelium was confined to areas adjacent to the tumor, and appeared 
Table II. Distribution of $19-9$ antibody binding to various adult glandular and mucosal epithelia.

\begin{tabular}{|c|c|c|c|}
\hline & $\begin{array}{ll}\text { No. of Total no of } \\
\text { positive cases tested } \\
\text { cases } & \text { positive }\end{array}$ & $\frac{\%}{6}$ & Pattern of activity \\
\hline $\begin{array}{l}\text { Colorectal } \\
\text { mucosa }\end{array}$ & $12 / 20$ & 60 & $\begin{array}{l}\text { Surface of crypt lining } \\
\text { celly. Cytoplasm of some } \\
\text { Goblet cells }\end{array}$ \\
\hline $\begin{array}{l}\text { Gastric } \\
\text { mucosa }\end{array}$ & $5 / 10$ & 50 & $\begin{array}{l}\text { Sumface of glandular epi- } \\
\text { thelium in the vicinity of } \\
\text { tumor } \\
\text { Cytoplasm of Goblet cells } \\
\text { in areas of intestinal } \\
\text { metaplasia }\end{array}$ \\
\hline Pancreas & $3 / 4$ & 75 & $\begin{array}{l}\text { Luminal cell border of the } \\
\text { ductal epithelium }\end{array}$ \\
\hline $\begin{array}{l}\text { Salivary } \\
\text { gland }\end{array}$ & $2 / 2$ & 100 & $\begin{array}{l}\text { Luminal cell border of the } \\
\text { ductal epithelium }\end{array}$ \\
\hline Gall bladder & $6 / 7$ & 86 & $\begin{array}{l}\text { Luminal cell surface and } \\
\text { cytoplasms of the columnar } \\
\text { epithelium }\end{array}$ \\
\hline Endocervical & $9 / 9$ & & $\begin{array}{l}\text { Cytoplasm of the columnar } \\
\text { epithelium in a focal dis- } \\
\text { tribution pattern }\end{array}$ \\
\hline
\end{tabular}

either as weak staining of the apical cell surface (fig. 4a) or as strong cytoplasmic staining of some Goblet cells in the crypt lining epithelium (fig. 4b). Breast, prostate and renal cortex epithelia did not show immunoreactivity with the antibody. Gastric epithelium only stained in areas of intestinal metaplasia or in the immediate vicinity of the tumor. Columnar cells in endocervical mucosa (fig. 5), salivary gland ductal epithelium (fig. 6), and pancreas showed marked immunoreactivity, particularly the gall bladder epithelium, which consistently showed intense staining (fig. 7). A focal staining pattern was generally observed in these tissues. 

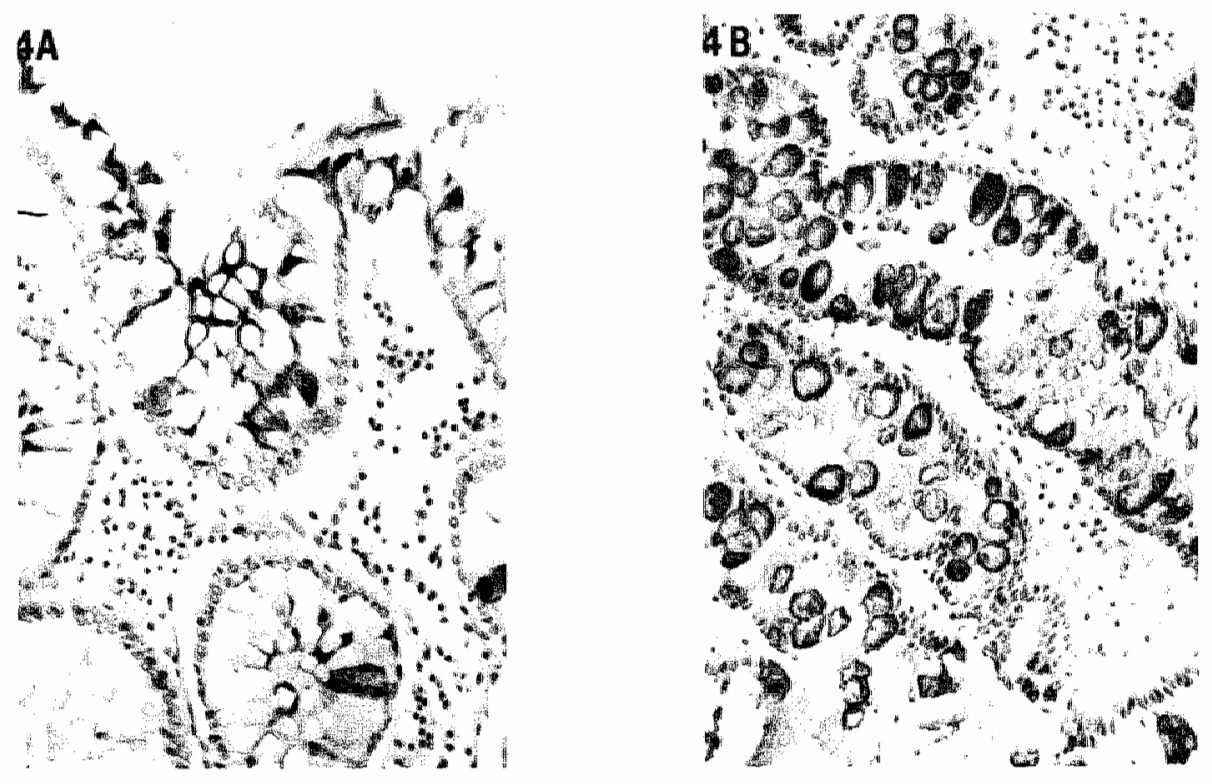

Figure 4. Colonic mucosa adjacent to adenocarcinoma. $A$ staining of the apical cell border is observed

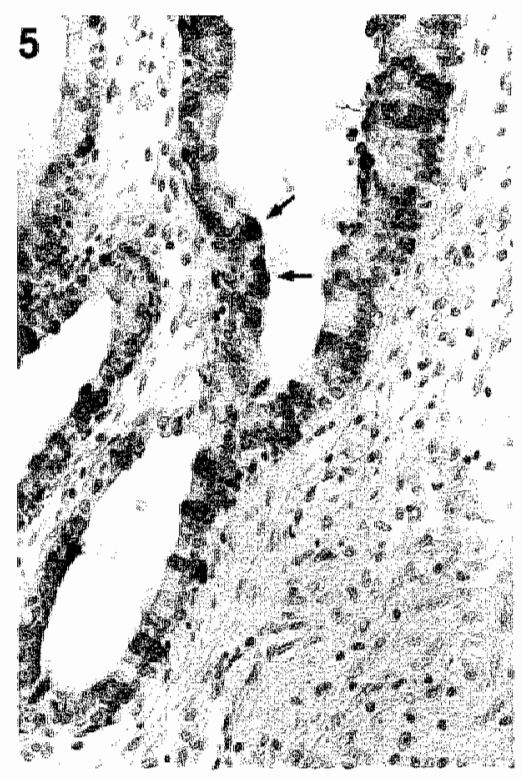
in (A) (x100), whereas mulliple reactive Goblet cells are observed in (B) $(x 100)$.

Figure 5. Normal endocervical glandular mucosa. Note the focal distribution pattern and a cytoplasmic staining reaction (arrow) $(x 100)$. 


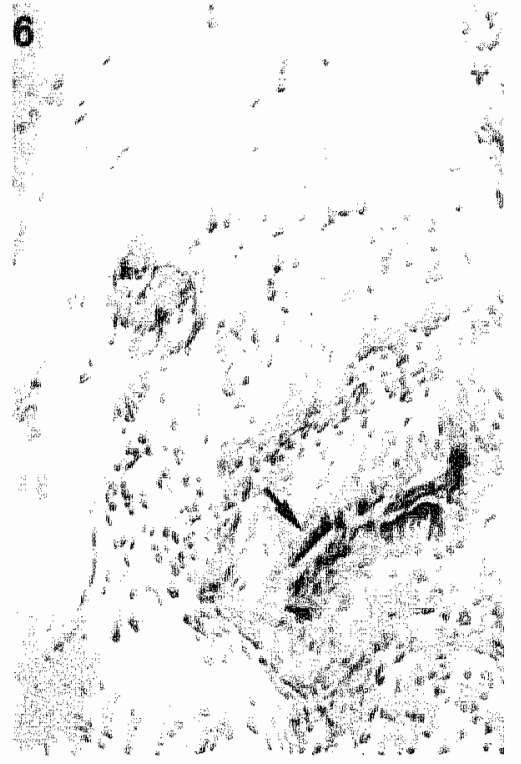

Figure 6. Duct of nomal salivary gland with a reaction product at the luminal cell border of the lining epithelium (arrow) $(x 60)$.

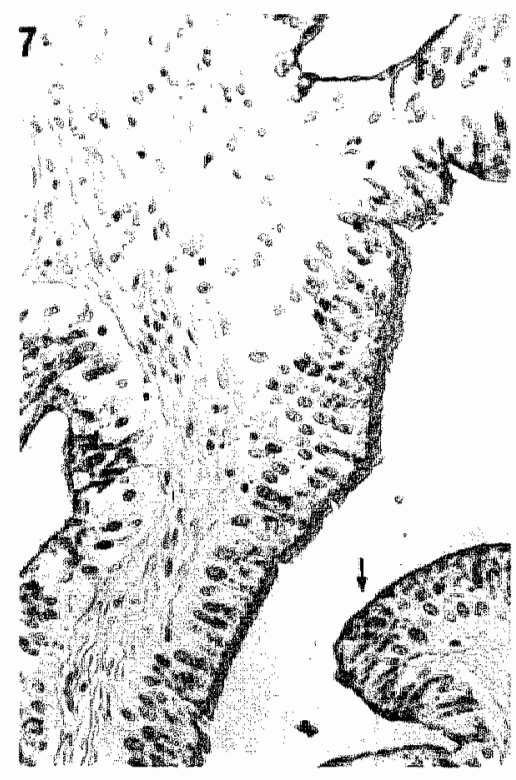

Figure 7. Normat mucosa of gall bladder with a staining of the apical cell border $(x 100)$.

\section{Fetal intestinal tissue}

Goblet cells of intestinal mucosa of 12-week embryos were positive for the 19-9 defined antigen, showing a moderate staining intensity (fig. 8a). In later stages of gestation, the antigen was also expressed on the brush border of the columnar epithelium in the small and large bowel (fig. 8b).

\subsection{Discussion}

The 19-9 monoclonal antibody against colon carcinoma was originally described as reactive only with colorectal carcinoma cells, and not with normal colonic epithelium or with carcinomas other than of the colon (1). It was also demonstrated that binding of this antibody to SW1116 colon carcinoma cells was inhibited by sera 

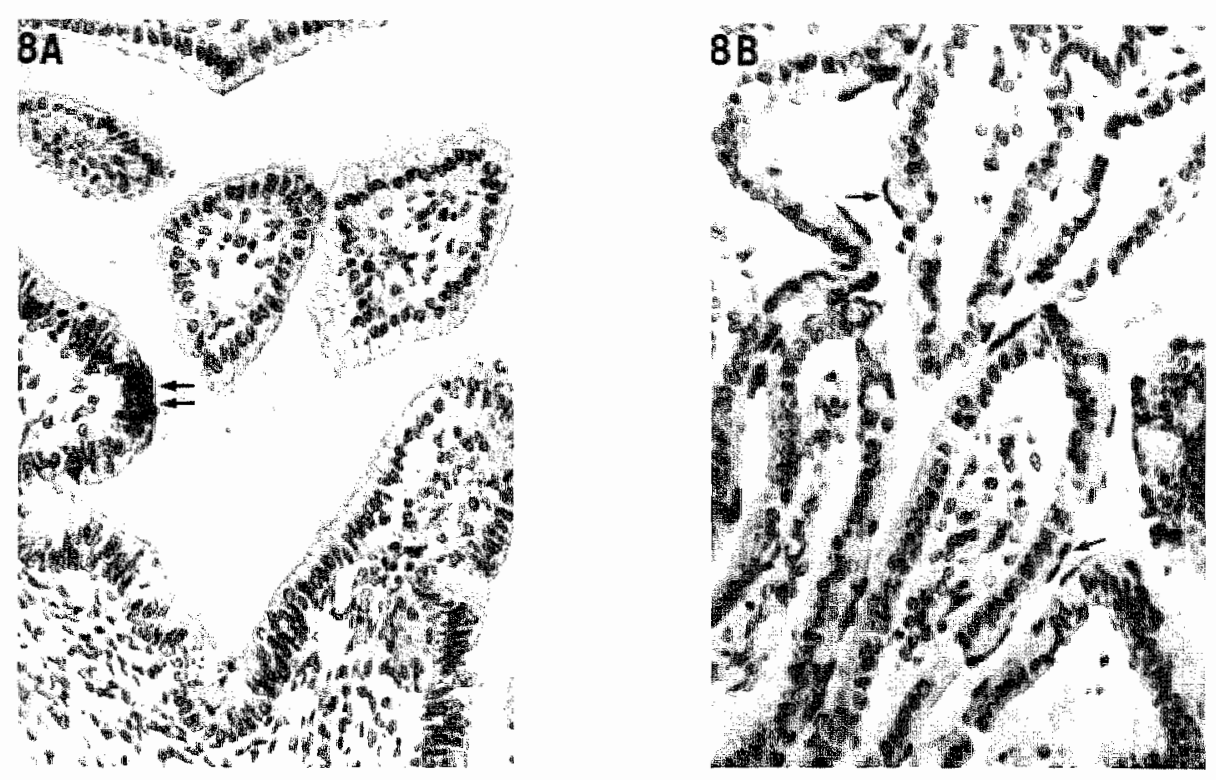

Figure 8, Intestinal mucosa of 12-week fetws (A). Note a few moderately stained Goblet cells (arrow) in the superficial mucosa. (x100). Intestinal mucosa of 22-week fetus (B). The reaction product is localized at the luminal cell surface (arrow) (x60).

from patients with adenocarcinoma of the colon, stomach and pancreas, but not by sera from patients with non-neoplastic intestinal discase or from healthy individuals $(2,4)$. Finally, the target antigen was identified as a monosialoganglioside, which could be detected in colorectal carcinoma tissue and meconium only (3), and which showed no immunologic similarity to carcinoembryonic antigen (CEA).

Those experimental data suggested that the antigen might be oncofetal and potentially useful for the detection of colorectal carcinoma. We decided to perform a systematic survey on the distribution of the antigen in various tissues, using an immunoperoxidase method. Tissue sections rather than cullured cells were chosen, because they play a substantial role in the selection and characterization of monoclonal antibodies with a desired specificity (5). The results indicate that the target antigen is not exclusively oncofetal, since it was detected in differentiated normal adult glandular epithelia, such as endocervix, gall bladder, pancreas and salivary gland. The 
distribution of the antigen in mildly fixed frozen sections closely paralleled that in trypsin-treated sections, excluding the possibility that antigenic properties were altered by routine tissue processing methods. Thus the discrepancies between results of tests on cell lines and on tissue sections cannot be explained by differences in the techniques used. The antigen, however, does appear to be present abundantly in most collorectal and endometrial adenocarcinomas, whereas it is absent or almost absent in normal mucosae as shown also by Atkinson et al (6). In adult colonic mucosa, the antigen appears to be localized only in areas adjacent to tumor tissue, either weakly staining the luminal surface of crypt lining cells, which could be the results of shedding of antigenic material into the surrouning lissue (2), or strongly staining the cytoplasm of a few Goblet cells. The intense staining of the latter cells suggested that they might produce the antigen. In individuals with positive Le phenotype (7-9), the antigen would be expected to be represented in the salivary glands and their secretions (9) since this particular monosialoganglioside represents a sialylated Le hapten (7-10).

The 19-9 target antigen appears to be more widely distributed than originally proposed. It is conceivable, however, that it is present in such small quantities in tumor adjacent epithelium that it can only be detected using a very sensitive immunoperoxidase procedure. Furthermore, cultures of cancer cells probably represent only a limited selection of the cells present in the original tumor and, in addition, may lose some characteristics of the original tumor during cultivation. For these reasons, immunohistochemical studies of cancerous tissues should be considered an essential step in the final characterization of antitumor monoclonal antibodies. If $\mathrm{so}_{3}$ the question remains whether this phenomenon indicates a premalignant alteration of normal mucosal epithelium (11) or a reaction to adjacent malignant cell proliferation (12). It is conceivable that the presence or absence of the 19-9 target antigen is related to the level of differentiation of colonic adenocarcinoma. This question is currently under investigation. 


\section{References}

1. Koprowski H, Steplewski $Z$, Mithoell K, Herlyn M, Herlym, Fuhner P. Colonecal carcinoma antigens detected by hybridoma antibodies. Somat. Cell Genet. 1979, 5: $957-972$.

2. Koprowksi $H$, Herlyn $M$, Steplewski $Z$, Sears HF. Specific antigen in sermim of pationts with colon carcinoma. Science 1981, 212: 53-55.

3. Magnani JL, Brockhaus $M$, Smith DF, Ginsburg V, Blaszezyck M, Mitchell KF,Sieplewski $Z$, Koprowski H. A monosialoganglioside is a monocional antiboy-defined antigen of colon carcinoma. Science 1981, 212: 55.56

4. Herlym M, Sears HF, Steplewski Z, Koprowski H. Monoclonal antibody detection of a circulating tumor-associated antigen. I. Presence of antigen in sera of patients with colorectal, gastrio and pancreatic carcinoma. J. CLir. Imamunol. 1982, 2: $135-140$,

5. Finan PJ, Grant RM, De Matos C, Takei F, Berry PJ, Lennox ES Blechen NM. Immunohisto. chemical techniques in the early screening of monoclomal antibodies to human colonic epithelium. Brit. J. Cancer 1982, 46: 9-17.

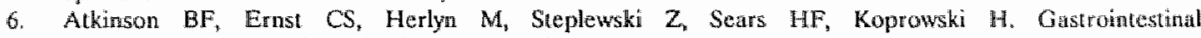
cancer-associated antigen in immunoperoxidase assay. Cancer Res. 1982, 42: 4820-4823.

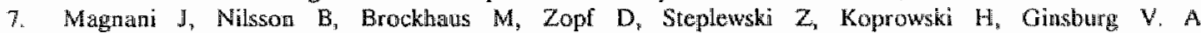
monoclonal antibody-defined antigen associated with gastrointestinal cancent is a ganghosido containing sialylated lacto-N-fucopentose II. J. Biol, Chem. 1982, 257:14365*1.4369.

8. Koprowski H, Brockhaus M, Blaszczyck Mi, Magnani J, Steplewski ZZ Lewis blood-type muy affect the incidence of gastrointestinal cancer. Lancet 1982, 12: 1332-1333.

9. Steplewski $Z$, Herlyn $M_{*}$ Blaszcryck $M$, Koprowski $H$. A simple prockdure for determinimg Lewis phenotypes in human saliva. J. Immunol. Meth. 1983, 62: 73.

10. Fialk K-E, Karlsson K-A, Larson $G$, Thurin $Y$, Blaszczyck $M$, Steplewski $Z$, Koprowski H. Mass spectrometry of a human tumor glycolipid antigen being defined by mousc monodonal antiboy NS 19-9. Biochem. Biophys, Res. Comm, 1983, 110: 383.391.

11. Filipe MI. The value of a study of the mucosubstances in rectul biopsies from patients with carcinoma of the rectum and lower signoid in the diagnosis of premalignant mucosa. J. CLin, pathol. 1972, 25: $123-128$.

12. Isaacson $P$, Attwood PRA. Failure to demonstrate specificity of the morphological and histochemical changes in mucosa adjacent to colonic carcinoma (transitional mucosa). If. Clin. Pathol. 1979, 32: 214-218. 


\section{MONOCLONAL ANTTBODY DEFINED MUCIN ANTIGENS OF NORMAL AND NEOPLASTIC HUMAN COLONIC MUCOSA: BIOCHEMICAL AND HISTOCHEMICAL CHARACTERIZATION}

\subsection{Introduction}

Large bowel cancer is one of the most frequently occurring tumours and, in spite of progress in the possibilities for surgical, radiation and chemotherapeutic treatment, fatal in about $60 \%$ of the cases due to recurrent or metastatic disease. Several attempts have been miade to generate Mo Abs which could be used for early identification of metastases by in vivo imaging and for drug targeting. As immunogens primarily colorectal cancer cell lines have been used, mainly resulting in Mo Abs against carcinoembryonic antigen and blood group related antigens $(1,2)$. These antigens, however, are fairly ubiquitously distributed in various tissues and tumor types.

Mucins are characteristic products of normal colonic mucosa and most colonic carcinomas. Various polyclonal antibodies have been raised against intestinal goblet cell glycoproteins (3-7). Only recently, mucin specific monoclonal antibodies have been obtained after immunizing with isolated colonic crypt cells (8) and fractionated colonic mucins (9). With these antibodies a remarkable heterogeneity of the colonic mucosal goblet cell population has been demonstrated (10). Such antibodies might be of diagnostic or prognostic importance as changes in mucin profiles have been observed in premalignant and malignant lesions of colonic mucosa (11-15). In attempts to obtain such Mo Abs we have used two different approaches. In order to generate Mo Abs reactive with formaldehyde fixed antigens, mice were immunized with homogenized formaldehyde fixed tumor tissues. Alternatively mice were immunized with mucin producing cells from a human colonic carcinoma cell line (16).

In the present report we describe the obtained macin-reactive Mo Abs, the biochemical characteristics of their target antigens and their reactivity with normal colonic tissues. 


\subsection{Materials and methods}

\section{Tissue and cell preparation}

Normal colon epithelium was obtained from colectomy specimens of patients with collonic carcinoma. The mucosa was dissected from the bowel wall at a distance of at least $5 \mathrm{~cm}$ from the tumor. The epithelial cells were separated from the lamina propria according to the method of Bull and Bookman (17). To this end $2 \mathrm{~cm}^{2}$ pieces of mucosa were washed in Phosphate Buffered Saline (PBS) $+1 \mathrm{mM}$ dithiothreitol (DTT) (30 min, room temperature) to eliminate adherent mucus and bacteria. In order to isolate the epithelial cells, mucosal fragments were incubated in PBS + $0.75 \mathrm{mM}$ Ethylene Diamine Tetra Acetate (EDTA) pH 7.4 (90 min, 37\% C). Dissociated epithelial cells were pelleted by centrifugation $(1000 \mathrm{~g})$ and resuspended in PBS (pH 7.4). 5583-S cells (16) were grown in Dulbecco's Modification Eagle's Medium (DMEM) $+10 \%$ Fetal calf serum (FCS). Cells were washed 3 times in cold PBS.

All further preparations were done at $4^{\circ} \mathrm{C}$ or on ice. One volume of packed, colonic cells or 5583-S cells was mixed with 4 volumes of PBS + $2 \mathrm{mM}$ Phenylmethanesulphonylfluoride (PMSF) (Sigma) and the cells were homogenized in a Sorvall omnimixer. The homogenates were centrifuged (5 min, $1000 \mathrm{~g})$ the pellet discarded and the supernatant was again centrifuged $(50.000 \mathrm{~g}, 20 \mathrm{~min})$. The pellet was discarded and the protein content of the supernatant cytosol was determined photometrically at $280 \mathrm{~nm}$. The cytosols were used as target antigens in enzyme immunoassays and for gelfiltration chromatography. For Perchloric acid (PCA) extraction 1 volume of cytosol was added to 1 volume of $1 \mathrm{M}$ PCA and stirred for 20 minutes. The precipitated material was centrifuged $(20.000 \mathrm{~g}, 15$ min) and the supernatant was dialyzed against distilled water (3 changes, 24 h). The precipitate was centrifuged and the supernatant was used for sodium dodecyl sulphate polyacrylamide gelelectrophoresis.

\section{Generation of Mo Abs}

In a first attempt Balb/c mice were immunized with formalin fixed colon cancer tissue homogenate. From each of ten formalin fixed tumor specimens, 1 gram of tumor tissue was collected and washed in $1.00 \mathrm{ml}$ PBS $(3 \mathrm{x} \quad 24 \mathrm{~h})$. Tissue fragments were pulverized in a Spex tissue homogenizer under liquid nitrogen (maximum speed, $5 \mathrm{~min})$. The mice were immunized intraperitoneally, with $100 \mu \mathrm{g}$ of tumor homogenate and boosted twice at monthly intervals. Four days after the final booster injection spleen cells were harvested 
and used for fusion. This approach resulted in Mo Abs PARLAM 2 and 3.

In the second attempt Balb/c mice were immunized with $5583-\mathrm{S}$ cells growing in suspension and producing large quantities of mucin. A similar immunization schedule was followed as for the first, using two immunizations with $200 \mu \mathrm{\mu l}$ and for the booster injection 100 $\mu$ l of packed cells. This approach resulted in the Mo Abs PARLAM $8-13$.

Spleen cells were fused with SP $2 / 0$ myeloma cells, in a ratio 2:1 and fused cells were seeded in four 96 well microtiter plates and grown on DMEM + 20\% FCS + Hypoxanthine, Aminopterin, thymidine (HAT). Antibody producing wells were cloned and recloned by limiting dilution until all clones were productive. Initial supernatant screening was performed by ELISA with cytosol of normal colonic tissue, colon carcinoma or 5583-S cells as target antigens. Antibody producing clones were further selected on the basis of tissue immunoreactivity patterns obtained through immunoperoxidase staining of frozen and paraffin sections.

Mo Abs Ig subclass was determined by an immuno spot test (18) using Ig subclass specific goat anti mouse immunoglobulins (Nordic, Tilburg, The Netherlands).

\section{Enzyme Linked Immuno Sorbent Assay (ELISA)}

ELISA's were performed on 96 well polystyrene plates (Greiner). The desired amount of antigen solution was diluted in PBS (0.05 to $0.1 \mathrm{~g}$ of protein in $50 \mu \mathrm{l} / \mathrm{well})$. Antigen was attached to the plates by overnight evaporation at $37^{\circ} \mathrm{C}$ in a dry incubator. Prior to application of the primary antibody the plates were treated with $0.1 \%$ bovine serum albumin (Sigma) in Phosphate Buffered Saline $+0.05 \%$ Tween 20 (PBS-Tween) to prevent nonspecific binding. Tissue culture supernatant containing $\mathrm{MO} A b$ or ascites, diluted in Phosphate Buffered Saline $+0.05 \%$ Tween $20+0.1 \%$ Bovine Serum Albumin (PBS-Tween-BSA) was incubated $1 \mathrm{~h}$ at $37^{\circ} \mathrm{C}$. After washing 3 times with PBS-Tween the plates were incubated with rabbit anti mouse immunoglobulin peroxidase conjugate (Dakopatts, dilution 1:400, $\left.1 \mathrm{~h} 37^{\circ} \mathrm{C}\right)$. After final washing peroxidase activity was visualized with ortho-phenylene diamine. The reaction was stopped after $1.5 \mathrm{~min}$ with $2 \mathrm{~N} \mathrm{H}_{2} \mathrm{SO}_{4}$ and the absorbance was measured at $492 \mathrm{~nm}$. 


\section{Inumunocytochemistry}

Details of the immunoperoxidase technique have been reported previously (19). Unfixed cryostat sections or $5 \mu \mathrm{m}$ paraffin sections were used. Endogenous peroxidase activity was blocked in $0.5 \%$ $\mathrm{H}_{2} \mathrm{O}_{2}$ in methanol. The paraffin sections were subjected to $0.1 \%$ trypsin in $0.1 \% \mathrm{CaCl}_{2}$ in distilled water $(\mathrm{pH} 7.8)$ for $25 \mathrm{~min}$ prior to immunostaining. Before staining, the sections were preincubated with $20 \%$ normal rabbit serum to prevent nonspecific binding. Mo Abs and rabbit anti-mouse immunoglobulin peroxidase conjugate were applied $30 \mathrm{~min}$ at room temperature. Between each incubation sections were rinsed $(3 \times 5 \mathrm{~min})$ with $0.05 \mathrm{M}$ Tris $0.9 \% \mathrm{NaCl} \mathrm{pH}$ 7.6. Peroxidase activity was visualized with $0.01 \% \quad \mathrm{H}_{2} \mathrm{O}_{2}$ and $0.05 \%$ diamino-benzidine in Tris (hydroxymethyl) methylamine (Tris- $\mathrm{HCl}$ ) buffer ( $\mathrm{pH}$ 7.6) and the sections were counterstained with hematoxylin. Negative controls included replacement of specific antibodies with SP $2 / 0$ supernatant or ascites.

\section{Western blotting}

SDS-PAGE was performed according to the method of Laemmli (20) on a $5 \%$ gel. The sample ( $40 \mu \mathrm{g}$ of PCA extract, normal colon cytosol or 5583-S cytosol) was diluted in a $62.5 \mathrm{mM}$ Tris- $\mathrm{HCl}$ pH 8.6 buffer containing $10 \%$ glycerol, $5 \%$ mercaptoethanol, $2.3 \% \mathrm{w} / \mathrm{v}$ SDS and $0.02 \%$ bromophenol blue. After electrophoresis $(200 \mathrm{~V}, 5 \mathrm{~h})$ the separated proteins were electrophoretically transferred onto nitrocellulose and immunostained according to Towbin et al. (21).

Gelliltration chromatography

A cytosol of 5583-S cells in PBS containing $2 \mathrm{mM}$ PMSF was filtered over a $0.45 \mu \mathrm{m}$ filter to prevent plugging of the column. $15.5 \mathrm{ml}$ of cytosol containing $51.8 \mathrm{mg}$ of protein was eluted on a sepharose $4 \mathrm{~B}$ column (2.6 $\times 85 \mathrm{~cm}$, Pharmacia) using PBS as eluent (11.5 $\mathrm{ml} /$ hour $)$. Protein content of each eluent fraction $(2.5 \mathrm{ml})$ was determined by OD 280 measurement and the reactivity of each fraction with the various Mo Abs was tested by ELISA.

\section{Competition experiments}

To investigate whether Mo Abs were directed against identical or closely related epitopes competition experiments were performed by ELISA. To this end each Mo $A b$ was labeled with horseradish peroxidase (Sigma, grade IV) according to the method of Wilson and Nakane (22). A fixed amount of 5583-S cell cytosol 0.05 to $0.5 \mu \mathrm{g}$ of protein per well) was coated on 96 well plates and incubated with a previously determined $50 \%$ saturating concentration of peroxidase 
conjugated Mo $\mathrm{Ab}$, together with a 50 fold excess of homologous or heterologous unlabeled competition antibody $\left(1 \mathrm{~h}, 37^{\circ} \mathrm{C}\right)$. Peroxidase activity was determined as described earlier.

\section{Epitope characterization}

To investigate protease sensitivity of the Mo Ab target epitopes, pronase digestion was used. To this end the cytosol fraction of $5583-\mathrm{S}$ cytosol $(0.3 \mathrm{mg} / \mathrm{ml})$ was incubated with pronase coupled to sepharose beads (Pierce, 6 units/ml in PBS) at $37{ }^{\circ} \mathrm{C}$ (under continuous stirring for 5 hours). After incubation the beads were removed by centrifugation $(1000 \mathrm{x} \mu \mathrm{g})$. The reaction mixture was coated on 96 well plates and the immunoreactivity of the various Mo Abs was tested by ELISA. As a control 5583-S cytosol incubated under identical conditions but without pronase was applied. To test thermal sensitivity the cytosols were boiled for $3 \mathrm{~min}$ in PBS and also tested in ELISA.

Periodate oxidation of the terminal sugar residues was performed according to Woodward et al.(23). To this end 5583-S cytosol (0.5 $\mu \mathrm{g}$ protein /well) was coated on 96 well plates, the wells were washed with PBS and incubated overnight with $50 \quad \mathrm{mM} \mathrm{NaIO}_{4}$ in $0.1 \mathrm{M}$ sodium acetate buffer $\mathrm{pH}$ 5.4. The reaction was stopped with $10 \%$ glycerol in PBS (30 min, room temp). As a control 5583-S cytosol was incubated under identical conditions but without periodate. Plates were washed 3 times with PBS and antibody binding was determined as described for ELISA.

For the Mo Abs showing reduced binding after periodate oxidation, the nature of the involved sugar residue was further investigated by digestion of coated antigens with exoglucosidases and by competition of antibody binding with lectins and monosaccharide solutions. Exoglucosidases were applied in $0.01 \mathrm{M}$ Sodium acetate buffer $\mathrm{pH} 5$ for 64 hours at $37^{\circ} \mathrm{C}(50 \mu \mathrm{l} / \mathrm{well})$. As exoglucosidases d-galactosidase (1.2 mU/well), d-acetylglucoseaminidase (2.5 mU/well), d-mannosidase ( $9 \mathrm{mU} /$ well), L-fucosidase $(1 \mathrm{mU} /$ well) all from Sigma and neuraminidase $0.5 \mathrm{mU} /$ well from Behring were used. Control incubations were performed under identical conditions but without the enzymes. Plates were washed with PBS and subsequently with PBS-Tween $+0.1 \%$ ovalbumin (Sigma). Antibody binding was again determined by ELISA. As lectins Peanut agglutinin (PNA), Soybean agglutinin (SBA), Concanavalin A (Con A), Pisum sativum agglutinin (PSA), Ulex europeaus agglutinin (UEA), Dolichos bifloris agglutinin (DBA), Pokeweed mitogen agglutinin (PWM), all obtained from Sigma were 
applied. The wells were incubated with $2 \mu \mathrm{g}$ of lectin in $50 \mu \mathrm{l}$ of peroxidase conjugated Mo Ab (1:1000 for PARLAM 8, 11, 12 and 13 and 1:200 for PARLAM 2, 3 and 10) in PBS-Tween BSA $\left(1 \mathrm{~h}, 37^{\circ} \mathrm{C}\right)$. After washing the conjugate binding was determined as described earlier.

Competition experiments with sugar residues were performed by simultaneous incubation of peroxidase conjugated $\mathrm{Mo} A b$ and monosaccharides in a concentration range from $0.0003 \%$ to $1 \%$ in PBS-Tween. The following sugars were tested: neuraminic acid, galactose, acetylgalactosamine, fucose, mannose and glucose. Antibody binding was determined as described earlier.

\subsection{Results}

\section{Immunocytochemistry}

The immunoperoxidase staining patterns of the monoclonal antibodies are shown in fig. 1. Four staining patterns could be distinguished. PARLAM 2 showed a focal, course granular staining pattern with a significant intra- and intercrypt variability. PARLAM 3 , 9 and 10 reacted diffusely with all goblet cells in normal colon. PARLAM 11 revealed reactivity with the apical plasma membrane of columnar cells. PARLAM 8, 12 and 13 reactivity was localized in the supranuclear cytoplasm, frequently showing more intense reactivity in transitional mucosa adjacent to neoplasms. Occasionally faint reactivity with normal colonic epithelium was noted. The immunoperoxidase staining patterns were similar on paraflin and frozen sections for all Mo Abs except for PARLAM 3,9 and 10. On paraffin sections PARLAM 3, 9 and 10 showed no or only faint reactivity, but after treatment with trypsin the staining pattern was similar to the pattern on frozen sections.

\section{Immunoblotting and gel filtration chromatography}

Antigens of PARLAM 3, 9 and 10 appeared to be heat sensitive so boiling was omitted. Under these conditions target antigens in a western blot of colon epithelium cytosol appeared as a single protein band of $87 \mathrm{kD}$ (fig. 2). The antigens of PARLAM 2, extracted with PCA from colonic carcinoma, appeared as a single high MW band ( $>400 \mathrm{kD}$ ) just entering the separating gel. The antigens of PARLAM 8, 11, 12 and 13, in crude 5583-S cytosol, did not enter the stacking gel indicating that they are part of a complex 

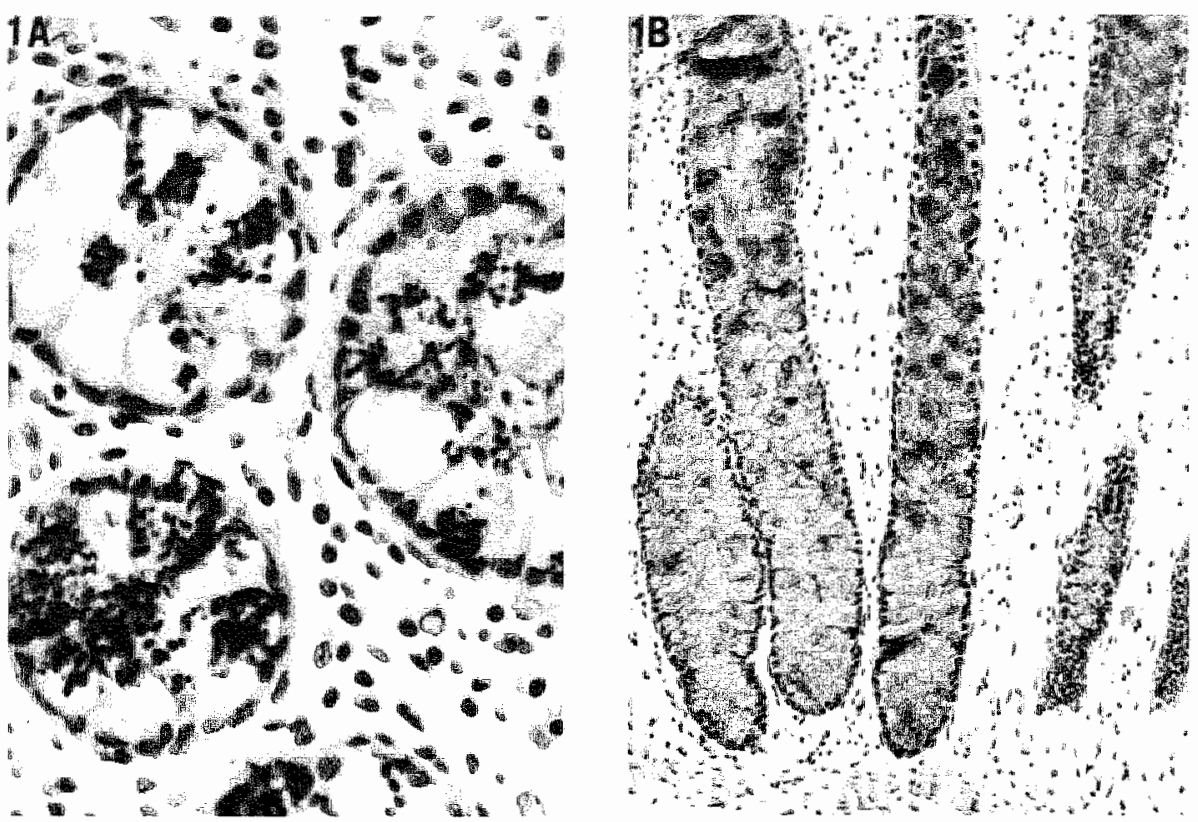

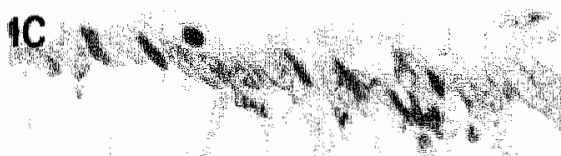

ID: $3, y$

3. $y 3$

70

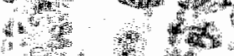

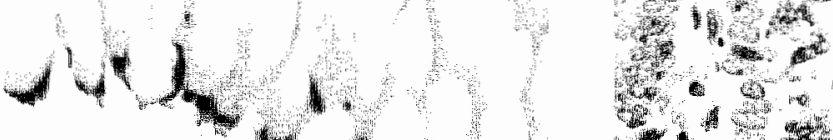

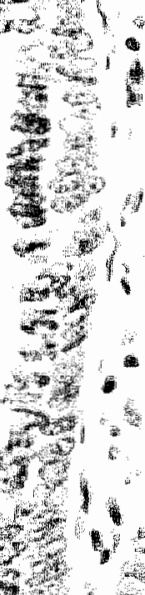

2.

Yo $\frac{1}{2}$

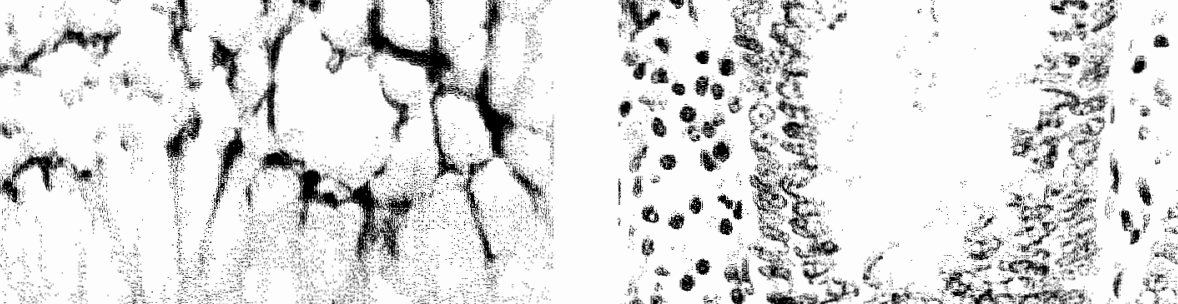

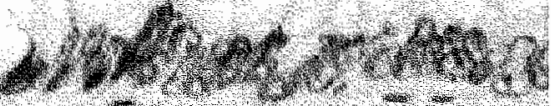

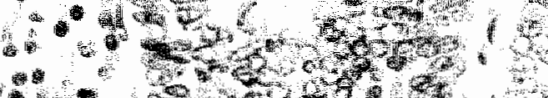

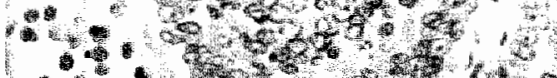

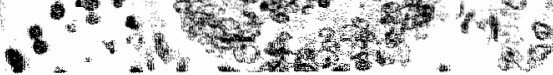



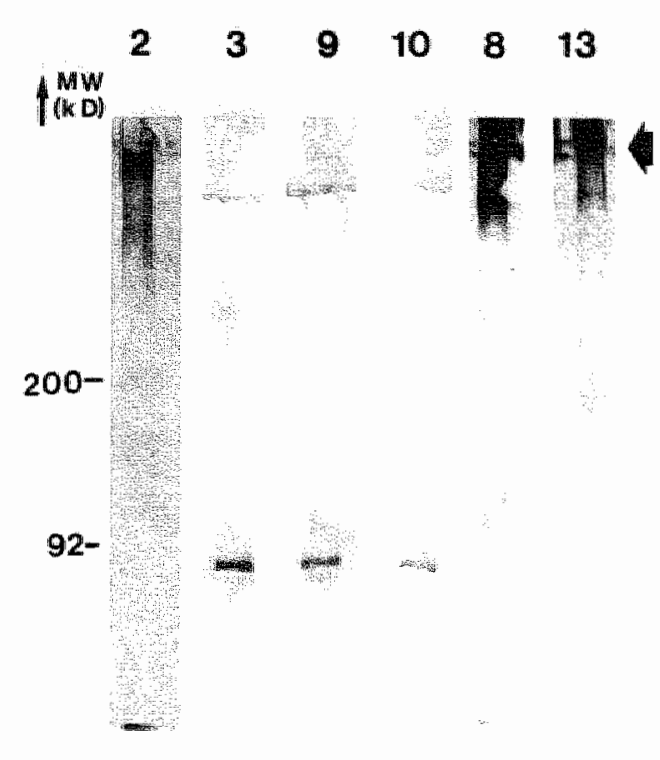

Figure 2. SDS-PAGE of antigens followed by immunoblotting with PARLAM MO Abs. For PARLAM 2 PCA extract of colonic carcinoma, for PARLAM 3, 9 and 10 colonic enterocyte cytosol and for PARLAM 8, 12 and 13 PCA extract of 5583-S cytosol was applied to the gel. Arrow indicates the beginning of the separating gel.

macromolecule (MW > 500kD). After PCA extraction, however, reactivity with PARLAM 8 and 13 (fig. 2) could also be detected in the high MW range ( $>400 \mathrm{kD}$ ). Gelfiltration elution patterns of PARLAM target antigens are shown in figure 3. On Sepharose $4 B$ most antigens cluted primarily in the void volume (PARLAM 2, 3, 11 and 12) or in the fractions immediately thereafter (PARLAM 8 and 13) corresponding to a molecular weight exceeding $5 \times 10^{\circ} \mathrm{kD}$ and all before the major protein peak. The antigens of PARLAM 9 and 10 eluted in the ascending slope of the protein peak, corresponding with a molecular weight of $2-5.10^{\mathrm{c}} \mathrm{kD}$.

TFigure 1. Inmunocytochemical staining pattern of the Mo Abs on normal colonic mucosa.

2A: Granular reactivity of PARLAM 2 with goblet cells (x340). 1B: Diffuse goblet cell staining with PARLAM 3, 9 and 10 (x135). 1C: Apical columnar cell staining with PARLAM 11 ( $\times 540)$.

1D: Supranuclear cytoplasmic goblet cells staining with PARLAM 8,12 and 13 (x340). 

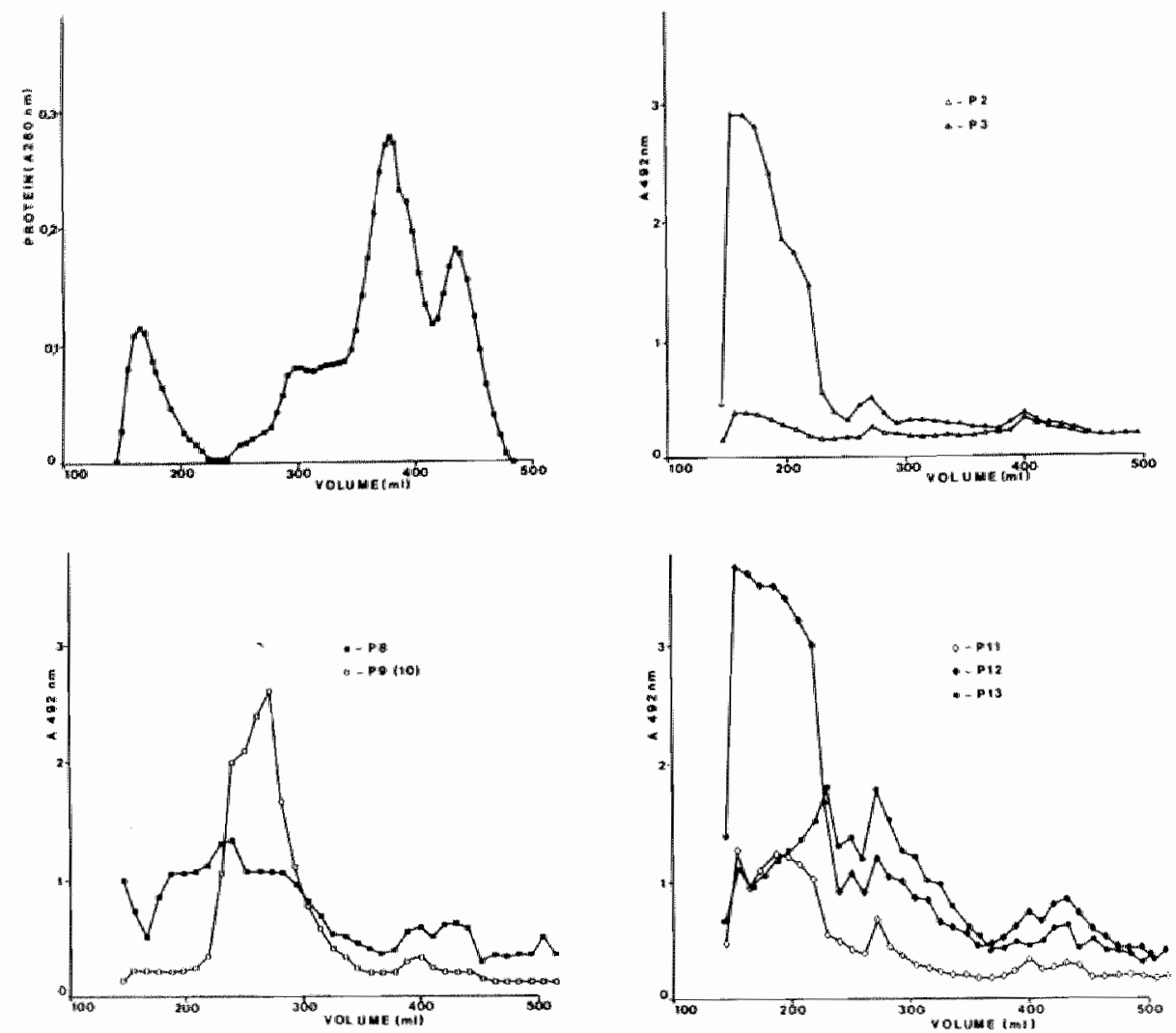

Figure 3. Protein elution pattern and elution patterns of PARLAM target antigens after gelfiltration of 5583-S cytosol on a Sepharose $4 B$ column.

\section{Competition experiments}

The results of the competition experiments are shown in table 1 . Binding of the conjugated monoclonal antibody could be completely blocked by the homologous unconjugated antibody. Futhermore binding of conjugated PARLAM 9 could be completely blocked by unconjugated PARLAM 10. In contrast PARLAM 9 did not block binding of conjugated PARLAM 10. The same phenomenon was observed with PARLAM 12 and 8. PARLAM 8 blocked binding of conjugated PARLAM 12 but PARLAM 12 did not block binding of PARLAM 8. 
In other combinations monoclonal antibodies did not or only weakly inhibit each others binding. Therefore, PARLAM 9 and 10 and PARLAM 8 and 12 were either directed to the same epitope but with different affinity, or the epitopes of the Mo Abs partially overlapped.

Table I. Homologous and heterologous antibody competition.

\section{Competition PARLAM}

\begin{tabular}{|c|c|c|c|c|c|c|c|c|}
\hline & & $\overline{3}$ & 8 & 9 & 10 & 11 & 12 & 13 \\
\hline & 3 & - & * & * & + & + & + & + \\
\hline & 8 & + & - & $\psi$ & + & + & 4 & + \\
\hline & 9 & + & + & - & - & + & + & + \\
\hline Labeled & 10 & + & + & + & - & + & + & + \\
\hline \multirow{3}{*}{ PARLAM } & 11 & + & + & + & + & - & + & + \\
\hline & 12 & + & - & + & + & * & - & + \\
\hline & 13 & + & + & + & + & 4 & + & - \\
\hline
\end{tabular}

* strong reactivity, no competition

- reduced reactivity, competition

\section{Epitope characterization}

Table II shows the influence of heating, periodate oxydation and pronase digestion of the antigens on Mo $\mathrm{Ab}$ binding.

Table II. Influence of various antigen treatments on $M O A b$ in ELISA.

Heating Pronase Periodate oxydation

\section{PARLAM}

\begin{tabular}{rrrr}
\hline 2 & 21 & 33 & 42 \\
3 & 61 & 77 & 68 \\
8 & 5 & -1 & 78 \\
9 & 68 & 46 & 0 \\
10 & 79 & 35 & 0 \\
11 & 14 & 4 & -10 \\
12 & 0 & 10 & 15 \\
13 & -7 & 15 & 89
\end{tabular}

difference between the reactivity of untreated and treated antigen, expressed as a percentage decrease of the reactivity of the un treated antigen. 
The reactivity of the target epitopes of PARLAM 2 and 3 was reduced by all treatments suggesting that in its structure carbohydrate and protein components are involved or that the epitope is conformational. The target epitope of PARLAM 8 and 13 was only affected by periodate oxydation, indicating that it is of carbohydrate nature. The reactivity of PARLAM 9 and 10 to the target epitope was reduced by heating as well as pronase digestion, indicating the protein nature of the epitope. The epitopes of PARLAM 11 and 12 were not affected by any treatment, suggesting extreme stability. Table III summarizes the results of the lectin and carbohydrate competition experiments and of exoglycosidase digestion. Treatment of target antigens with galactosidase reduced binding only of PARLAM 13. Other exoglycosidases did not affect Mo Ab binding. The binding of PARLAM 8 was reduced by peanut lectin and of PARLAM 12 and 13 by peanut and soybean lectins. Galactose reduced binding of PARLAM 13. Other sugars did not affect Mo Ab binding.

Table III. Mo Ab binding inhibition by lectins, disaccharides and exoglycosidases.

\begin{tabular}{|c|c|c|c|c|c|}
\hline Inhibitor & & & RLA & & \\
\hline & 2 & 8 & 11 & 12 & 13 \\
\hline $\begin{array}{l}\text { Con A (Man, Gluc) } \\
\text { Soybean (Ga), nAC-Gal) } \\
\text { PNL (Gal, nAc-Gal) }\end{array}$ & - & $\begin{array}{l}- \\
-\end{array}$ & $\begin{array}{l}- \\
-\end{array}$ & $\begin{array}{r}- \\
++ \\
+\end{array}$ & $\begin{array}{r}1 \\
++ \\
+ \\
++\end{array}$ \\
\hline Galactose & - & - & - & - & + \\
\hline Ga lactosidase & \pm & \pm & - & - & $+t$ \\
\hline
\end{tabular}

\begin{tabular}{ll}
\hline & no inhibition \\
+ & slight inhibition \\
+ & strong inhibition \\
++ & very strong inhibition \\
+ & carbohydrate specificity of lectin
\end{tabular}




\subsection{Discussion}

Goblet cells represent one of the major cell types of the human colon epithelium and their main product, mucin, plays an important role in normal colon function. Early studies on colonic mucin from various species suggested that colonic mucin consists of a single high molecular weight glycoprotein complex (24). More recent studies, however, have shown that colonic mucin contains various different glycoproteins (25). Podolsky and Isselbacher (26) purified mucin from human colonic mucosa (HCM) and found at least six different mucin species, each with a distinctive hexose, hexosamine and aminoacid composition. Monoclonal antibodies raised against these mucins allowed the recognition of a striking degree of heterogeneity among colonic goblet cells (10). In spite of increasing attention for structural and lunctional properties of mucin the knowledge concerning the molecular structure of mucin associated glycoproteins and their function in health and disease remains rather fragmentary.

Considarable attention has been paid to changes in mucin profiles in colonic epithelial neoplasms and in the normal mucosa adjacent to these tumours. Abnormalities have been documented in adenomas and carcinomas as well as in the so-called "transitional" mucosa using conventional histochemical staining techniques $(27,12,14)$ lectin probes $(15,28,29)$ as well as immunocytochemical techniques. In the latter, antisera have been used which were raised against high molecular weight glycoproteins such as CSA-p (5), GOA (3), M1 and M3 (30, 31). Monoclonal anti-mucin antibodies have been rarely reported after immunization with colonic cancer cells. Various Mo $A b s$, induced against ovarian $(32,33,34)$ and mammary (35, 36), carcinoma were reported to react with mucin epitopes, also present in normal colon goblet cells.

The elegant studies by Podolsky et al. (9-10) illustrate that further elucidation of the molecular structure and cellular distribution of mucins in normal as well as in pathological conditions will be greatly facilitated by the availability of mucin specific Mo Abs. Against that background we attempted to obtain mucin reactive Mo Abs through immunization with (formalin fixed) colon cancer tissue or mucin producing colon cancer cells. Altogether 8 mucin reactive Mo Abs were obtained which appear to belong to four different groups based on their immunocytochemically determined intracellular distribution and on the molecular characteristics of their target antigens. The characteristics of these Mo Abs are summarized in table IV. 
Table IV. Compilation of the characteristics of the PARLAM series.

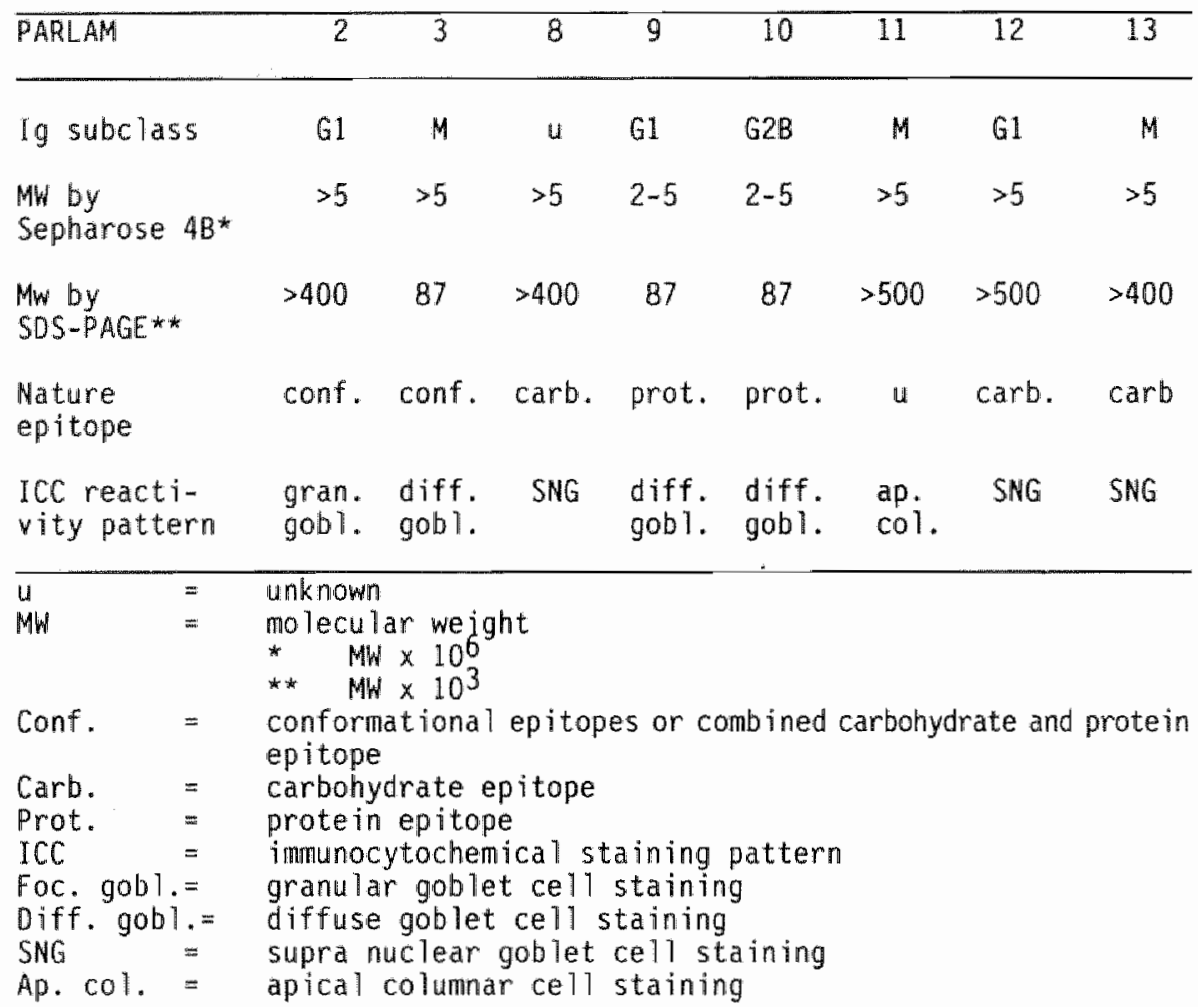

The first group consists of PARLAM 3, 9 and 10. By Sepharose 4B gelchromatography the target antigens are high molecular weight $25 \times 10^{6} \mathrm{kD}$ glycoproteins which share a $87 \mathrm{KD}$ non glycosylated protein, containing the target epitope according to the Western blotting experiments. The protein nature of the epitope is confirmed by its heat lability and its sensitivity to pronase digestion. Homologous and heterologous competition experiments show that the epitopes of PARLAM 9 and 10 are closely related (PARLAM 10 blocks the binding of PARLAM 9).

Immunocytochemistry shows a diffuse goblet cell cytoplasmic distribution of the antigen. The pattern of staining corresponds to that of Mo Abs 2, 3, 5, 11 and 12 from Podolsky's series (9-10). However, these Mo Abs were partly directed against protein related and 
partly against oligosaccharide related epitopes. Our PARLAM 3, 9 and 10 therefore identify closely related epitopes on a 7090 $\mathrm{KD}$ protein of a natively complexed large $\left(25 \times 10^{6} \mathrm{KD}\right)$ goblet cell glycoprotein as described by Pearson et al. (37) for gastric mucosa.

The second group consists of PARLAM 8, 12 and 13. By Sepharose 4B gelchromatography, the target antigens of these Mo Abs are large ( $>5 \times 10^{6}$ D) glycoproteins. The appearance of the target antigens of PARLAM 8 and 13 in the high MW range in western blots after PCA extraction suggests that these are complex molecules consisting of smaller subunits. Periodate oxydation sensitivity suggests that the target epitopes reside in the carboxyhydrate moiety, which is confirmed by the thermal stability and pronase resistance. Lectin and disaccharide competition experiments and exoglycosidase treatment suggest that galactose and N-Ac-galactosamine are part of the epitope structure of the PARLAM 12 and 13 epitopes, which according to blocking experiments, however, appear not to be identical. By immunocytochemistry the target antigens show a granular, supranuclear localization, suggestive of an association with the Golgi complex.

PARLAM 2 is the third category. Our experiments do not allow a final conclusion regarding the nature of the target epitope of this Mo $\mathrm{Ab}$, which resides on a large (>400 kD) complex glycoprotein. Its unique granular cellular distribution corresponds to that of Mo Abs 4, 9 and 14 of Podolsky's series, of which the epitopes of 9 and 14 also remained unidentified. The fourth category is PARLAM 11, which recognized an unidentified epitope in a large $\left(>5 \times 10^{5}\right.$ D) glycoprotein with an apical cytoplasmic localization. This distribution corresponds to that of Mo $\mathrm{Ab} 8$ of Podolsky's series.

In conclusion, we have obtained Mo Abs partly against protein related partly against carbohydrate related epitopes of large molecular weight mucin glycoproteins of colon cancer cells which react with normal colonic mucosa in 4 distinctly different patterns. These antibodies may be used for further studies concerning the molecular structure of these complex macromolecules as well as their distribution in normal and neoplastic colonic epithelia. 


\section{References}

1. Koprowsh, H., Steplewsti, Z, Mitchell, K., Herlyn, M., Herlyn, D., Fuhrer, P., Colorectal carcinoma anigens detected by hybridoma antbodies. Somatic Call Genet. 1979. 5: 957 972

2. Finan, P.J, Grant, R.M, De Mathos, C., Takei, F, Berry, PJ, Lennox, Es, Bleehen, N.M., Imounohistochemical techuiques in the carly screenimg of monoclonal antabodics to human colonic epithelium. Br. J. Cancer 1982, 46: 9-17.

3. Rapp, W, Windisch, $M$, Peschke, $P$, Wurster, $K$, Purification of human intestimal gobtet cell antigen $\left(G O A^{2}\right)$, its immunohistological demonsteation in the intestine sand in $m u c u s$. producing gastrointestinal adenocarcinomas, Wirch. Arch. A 1979, 382: 163-177.

4. Gold, D. $V_{*}$ Inmunoperoxidase localization of colonic mucoprotein antigen in neoplastic tisswes. Cuncer Res. 1981, 41: 767.772

5. Shochat, D., Archey, R.L, Pant, KD., Dahlman, H.L., Gold, D.V., Goldenberg, D.M., Characterization of colon-specific antigen-p and isolation of immunologically active tryptic peptides. J. Ifnmunol. 1981, 126: $2284-2289$.

6. Chakrabarty, S. Taylor, Ch.W, Yeoman, LC. Isolation and partial characterization of a 700 kilodaiton humat colon curcinoma associated antigen Cancer Biochem. Biophys. 1983 , 6: 249. 259 .

7. Nicholls, R.I., Sonthgatc, J., Trejdosiewicz, L.K., Antibodies to normal human colog membranes: preparation, characterization and tissue distribution. Histochem. J. 1985, 17: 717-729.

8. Hughes N.R., Walls, R.S., Newland, R.C., Payne, J.E. Antigen expression in normal and neoplastic colonic mucosa? Three tissuespecufic antigens using monoclonal antibadies to isolated colonic glands. Cancer Res, 1985, 46: 2164-2171.

9. Prodolsky, D.K., Fonrmier, D.A. Jynch, K.E., Development of anti-human colonic macin monoclonal antibodies. Characterization of multiple colonice mucin species. J. Clin. Invest. $1986 a, 77: \quad 1251-1262$.

10. Podolsky, D.K., Fournier, D.A., Lynch, K.E., Human colonic goblet cells. Demonstration of distinet subpopulations defined by mucin-specific monoclonal antibodies. J. Clin. Invest. 19866, 77: $1263-1271$.

11. Gold, D.W. Millar F." Characterization of human colonic mucoproten antigen. FmmunochemisUry $1974,11: 369-375$.

12. Greaves, P., Filipe, M.E. Branfoot, A.C., Transitional mucosa and survival in human colorectal cancer. Cancer 1980, 46: 764-770.

13. Greaves, P., Filipe, M.I. Abbas, S, Ormerod, M.G., Sialomucias and carcinoembryonic: antigen in the evolution of coloretal cancer. Histopathol. $1984,8: 825834$.

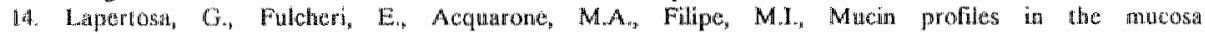
adjacent in liarge bowel non-adenocarcinoma neoplasias. Histopathol. 1984, 8: 805-811.

15. Aotand, C.R.; Montgomery, C.K., Kim, Y.S., Alterations in humata colonic mucin bccusring wh colluth differentiation and malignani transformation. Proc. Natl. Acad. Sci. USA. 1982, 79: 2051-2055.

16. Vorsijnen, C.P.H., A., Arends, J.W. Moerkerk, P.T.M., Geraedts, J., Sekikawa, K., J.P.M., Vitandal, M.P. Bosman, F.T., The establishmem and characterization of dwo new cell lines deriwed from a single human colonic adenocarcinoma. Virch Arch. B. 1987, 53. 191197.

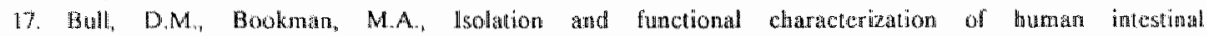
mecosal Iymphoid cells. J. Clin. Inwest. 1977, 59:966:974.

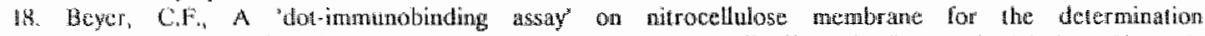
of the immunoglobulin eluss of mouse monoclonal antibodies. I. Immunol. Meth 1984, 67: 79.87.

19. Arends, J.W., Verstijne $n_{n}$ C. Bosman, F.T. Higers, Y. Steplewski, Z, Distribution of monodonal antibody-delined monosialoganglioside in normal and cancerous tissues: an immenoperoxidase study. Hybridoma 1983, 2: 219-229.

20. Latumli, U.K., Cleavage of structural proteins during the assembly of the bead of bacteriophage 7"4. Naiure 1970,227 : $680-685$.

21. Towbin, H, Stachelin, Th., Gordon, J, Electrophoretic transfer of proteins from polyacrylamide gets to mitrocellulose sheets: procedure and some applications. Proc. Natl. Acad. Sci. USA $1970,76: 4350-4354$. 
22. Wison, M.B, Nakane, P.K., Recent developments in periodate nethod of conjugating horseradish peroxidase (HRPO) to antibodies. In: Immunofuoracence and related stainug lechuopes, Knapp W. et al. Elsevier/North Holland Biochemical Press Amsterdam 215 (1978).

23. Woodward, M.P., Young, W.W. J J Boodgood, R.A., Detection of monoclonal antibotics specific for carbohydrate epitopes using periodate oxidation. J. lnumund. Meth. 1985, 78: $143-153$.

24. Allen, A., Pain, R.H., Robson, T.R. Model for the structure of the gastric mucous ggel. Nature $1976,264: 88-89$.

25. LaMont, J $T_{*}$ Ventolit, As, Purification and composition of colonic epiahelial mucin. Biochina. Biophys. Acta 1980, 626: 234-243.

26. Podolsky, D.K., Isselbacher, KJ,, Glycoprotein composition of colonic mucin. Gastrotaturo. logy 1984, 87: 991-998.

27. Reid, P.E., Owen, D.A., Dunn, W.L., Ramey, C.W., Lazosky, D.A., Chay, MGi., Chemical and thistochemical studies of normal and diseases human gastrointestinal tratcl. Bn. Changes in the histochemical and chemical properties of the epithelial glycoproteins in the mucosa close to colomic tumours. Histocbem. J. 1985, 17: 171-181.

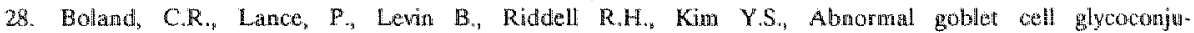
gates in rectal biopsies associated with an increased risk of meoplasia in paticnts wilh ulcerative colitis: early results of a prospective study. GUTI 1984, 25: 1364-1371.

29. Bresalier, R.S., Boland, C.R., Kim, Y.S., Regional differences in normal and cancer-associated glycoconjugates of the human collon. IMCI j985; 75: $249 \cdot 260$.

30. Bara, J., Burtin, P., Mucusmassociated gastrointestinal antigens in transitional mucosa adjaccon 10 human coloaic adenocarcinomas: their 'fetal-type' association. Europ. J. Cancer 1980at, 1.6: $1303-1310$.

31. Bara, I., Loisillier, F., Burtin, P., Antigens of gastric and intestinal mucous cells in human colonic tumours. Br. J. Cancer 1980b, 41: 209-221.

32. Ma, J., Handley, C.J., De Boer, W.G.R.M. An ovarian tumour specilic nutcin arutigen: inumunohistological and biochemical studies. Pahology 1983, 15: 385.391.

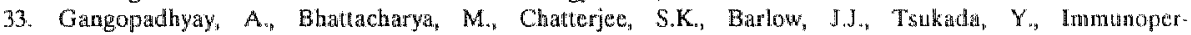
oxidase localization of a high-molecular-weight mucin recognized by monoclonal antibody 1D. Cancer Res, 1985, 45: 1744-1752.

34. Matres, M.J., Look, K., Lewis, J.L. Ir, Old, L.J., Lloyd, K.O., Thare mouse monaclonal antibodies to human differentiation antigens: reactivity with two mucin-like andigeris and with connective tissue fibers. J. Histochem. Cytochem. 1985, 33: 10951102,

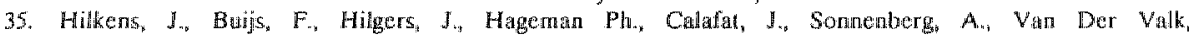
M.* Monoclonal antilodies against human milk-fat globule membranes detecting dinerentistion antigens of the mammary gland and its lumors. Int. J. Cancer 1964, 34: 197.206.

36. Stramignoni, D., Bowen, $R_{\text {, A }}$ Atkinson, B.F, Schlom, Ji, Differential reactivity of manoclanal

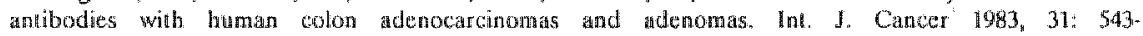
552.

37. Pearson, S.P., Allen, A. Parry, 5., A 70000-molecular-weight protela isolated from purified pug gastric mucus glycoprotein by reduction of disuphide bridges and in inaplication in the polymeric structure. Biochem. J. 1981, 197: 155-162. 
5. TISSUE DISTRIBUTION OF MUCIN REACTIVE MONOCLONAL ANTBBODIES IN NORMAL AND NEOPLASTIC HUMAN TISSUE

\subsection{Introduction}

Several investigators have reported the generation of Mo Abs against primary colon carcinoma cells, membrane preparations of colon cancer tissue or colonic carcinoma cell lines (1-6). None of these appeared to -react exclusively with either colonic epithelium or colonic carcinoma cells. One Mo Ab was found to detect a mucin antigen which occurred in normal as well as carcinomatous colonic epithelium (2). The organ specificity of this antigen, however, was not reported.

More recently, Mo Abs have been obtained through immunization with normal colon crypts (7), human colonic mucin (8) and colonic epithelial membrane preparations (9). Using his Mo Abs, Hughes et al. (7) showed alterations of mucin antigen patterns in normal colonic mucosa of colon cancer patients as well as altered mucin composition in adenoma and carcinoma tissues. Podolsky et al. (10) described a library of Mo Abs which showed distinct patterns of binding to goblet cell subpopulations in normal colonic mucosa which might also be of use in detecting alterations in histologically normal mucosa in patients with colonic disorders. Richman and Bodmer (9) demonstrated that Mo Abs can be used to define patterns in lumors which might assist in more accurate tumor characterization. In a previous paper we have described eight monoclonal antibodies generated against colon cancer cells and reactive with normal colonic mucosa in four distinct staining patterns. The monoclonal antibodies were generated in search for colon (cancer) tissue specific or associated antigens of potential value in vitro for immunohistological classification of colorectal cancer or in vivo for diagnostic or therapeutic targeting procedures. Attempts to biochemical characterization of the corresponding antigens, which is important in order 
to understand the chemical and functional nature of the antigens, have been described in the previous paper (11). These studies showed that the monoclonal antibodies could be subdivided into four distinct subgroups according to the characteristics of the target antigen and their binding patterns to normal colonic mucosa. Immunocytochemical analysis might provide clues regarding the function of the antigens and furthermore is necessary to establish their usefuiness for tissue diagnosis. We therefore studied the distribution of the antigens immunohistochemically, paying special attention to mucin reactivity, colon specificity, cancer specificity, species specificity and developmental expression.

\subsection{Material and methods}

\section{Monoclonal antibodies}

The monoclonal antibodies were obtained by immunizing mice with formalin fixed colon carcinoma tissue (Parlam 2 and 3) or with the mucin producing cell line 5583-S (PARLAM 8 up to 13). Biochemical characteristics of the antigens are extensively described in the previous paper (11).

\section{Tissue panel}

Reactivity of the Mo Abs with a panel of normal and neoplastic human tissues was determined. Paraffin embedded tissue specimens were retrieved from the files of the Department of Pathology of the University Hospital Maastricht. These included 9 normal colon specimens, 10 colon adenomas and 13 colon carcinomas. Furthermore the reactivity of the Mo Abs with various other normal and malignant tissues was investigated.

Paraffin embedded tissues of fetal and newborn colon, small intestine and stomach were obtained from Prof. J. Huber (Pediatric Pathology, State University Utrecht, The Netherlands). Specimens were available of mid-gestation (week 12, 16.5, 19, 22, 24, 25, 26 (2x), 27 (3x) and end-gestation (week 29, 30, 33 and 36) and at birth (2 weeks, 10 weeks, 12 weeks and 16 months). Fresh normal colon and colon cancer tissue was obtained from colectomy specimens of patients with colonic carcinoma.

Species specificity was investigated on paraffin embedded specimens of rat (Wag/ry) and mouse (Balb/c and NMRI) colon and small intestine. 


\section{Immunocytochemistry}

Details of the immunoperoxidase technique have been reported previously (12). $5 \mu \mathrm{m}$ paraffin sections were used. Endogenous peroxidase activity was blocked in $0.5 \% \mathrm{H}_{2} \mathrm{O}_{2}$ in methanol. The paraffin sections were subjected to $0.1 \%$ trypsin in $0.1 \% \mathrm{CaCl}_{2}$ in distilled water ( $\mathrm{pH}$ 7.8) for $25 \mathrm{~min}$ prior to immunostaining. For staining with monoclonal antibodies, the sections were preincubated with $20 \%$ normal rabbit serum to prevent nonspecific binding. Mo Abs and rabbit anti-mouse immunoglobulin peroxidase conjugate were applied $30 \mathrm{~min}$ at room temperature. Between each incubation sections were rinsed $(3 \times 5 \mathrm{~min}$ ) with $0.05 \mathrm{M}$ Tris $0.9 \% \mathrm{NaCl} \mathrm{pH} \mathrm{7.6.} \mathrm{Peroxidase}$ activity was visualized with $0.01 \% \mathrm{H}_{2} \mathrm{O}_{2}$ and $0.05 \%$ diamino-benzidine in Tris-HCl buffer ( $\mathrm{pH}$ 7.6) and the sections were counterstained with hematoxylin. Negative controls included replacement of specific antibodies by $\mathrm{SP} 2 / 0$ supernatant or $\mathrm{Sp} 2 / 0$ ascites. Immunoreactivity was compared on frozen and paraffin embedded tissue section of the same tissue specimen containing normal mucosa and malignant tissue.

The tissue sections were viewed independently by two investigators (JW.A., C.V.). In most incidences observations were confirmatory. Whenever discrepancies occurred, the slides were jointly reviewed and a single score was assigned by mutual agreement.

\subsection{Results}

\section{Reactivity in normal colonic mucosa}

No significant differences were observed between the staining patterns on frozen and paraffin embedded tissue. Table 1 shows the reactivity pattern of our Mo Abs with normal colonic mucosa. Four distinct staining patterns could be discerned in normal colonic mucosa (Fig. $1 \mathrm{~A}, 2 \mathrm{~A}, 3,4)$ : diffuse cytoplasmic reactivity with all goblet cells (PARLAM 3, 9 and 10), focal supranuclear reactivity, especially with the crypt base goblet cells (PARLAM 8, 12 and 13), focal coarse granular staining with goblet cells (PARLAM 2) and apical immunoreactivity with columnar cells (PARLAM 11). PARLAM 12 and 13 also occasionally showed diffuse cytoplasmic staining with goblet cells limited to the top of the crypts. With the exception of PARLAM 8, all monoclonal antibodies reacted with the majority of normal colonic tissue specimens (Table I). 
Table I. Staining pattern of PARLAM Mo Abs on normal colonic tissue.

\begin{tabular}{l|cc|ccc|c|c|}
\hline Group & \multicolumn{2}{|c|}{ I } & & II & III & IV \\
\hline PARLAM nr. & 3 & $9 / 10$ & 8 & 12 & 13 & 2 & 11 \\
\hline $\begin{array}{l}\text { Columnar cells } \\
\text { Brushborder overall }\end{array}$ & & & & & & & \\
Brushborder focal & - & - & - & - & - & - & 5 \\
& & & - & - & - & - & 2 \\
Goblet cells & 8 & 7 & - & - & - & 1 & - \\
Mucus overall & 1 & 2 & - & 1 & 2 & - & 1 \\
Mucus focal & - & - & - & 5 & 2 & - & - \\
Mucus superficial crypt & - & - & - & 2 & 3 & - & - \\
Supra nuclear granules overall & - & - & - & 1 & 2 & - & - \\
Supra nuclear granu les focal & - & - & 3 & 2 & 2 & - & - \\
Coarse granuar granules overall sporadic & - & - & - & - & - & 2 & - \\
Coarse granula focal & - & - & - & - & - & 3 & 1 \\
Coarse granula sporadic & - & - & & - & - & 3 & \\
\hline Total nr. with staining & 9 & 9 & 3 & $8^{*}$ & $9 *$ & 9 & 9 \\
\hline
\end{tabular}

In some specimens PARLAM 12 and 13 show more than one staining pattern

- $\quad=$ negative

sporadic $=0-5 \%$ of cells positive

focal $=5-80 \%$ of cells positive

overall $=80-100 \%$ of cells positive

Mo $A b$ reactivity in various species

In comparison with human intestinal mucosa, mouse and rat small and large intestinal mucosa reacted only weakly with PARLAM 11 and 13. PARLAM 11 reacted focally with goblet cells and brushborder apices. PARLAM 13 showed supranuclear reactivity especially in superficial goblet cells in colon and on villi in the small intestine. 

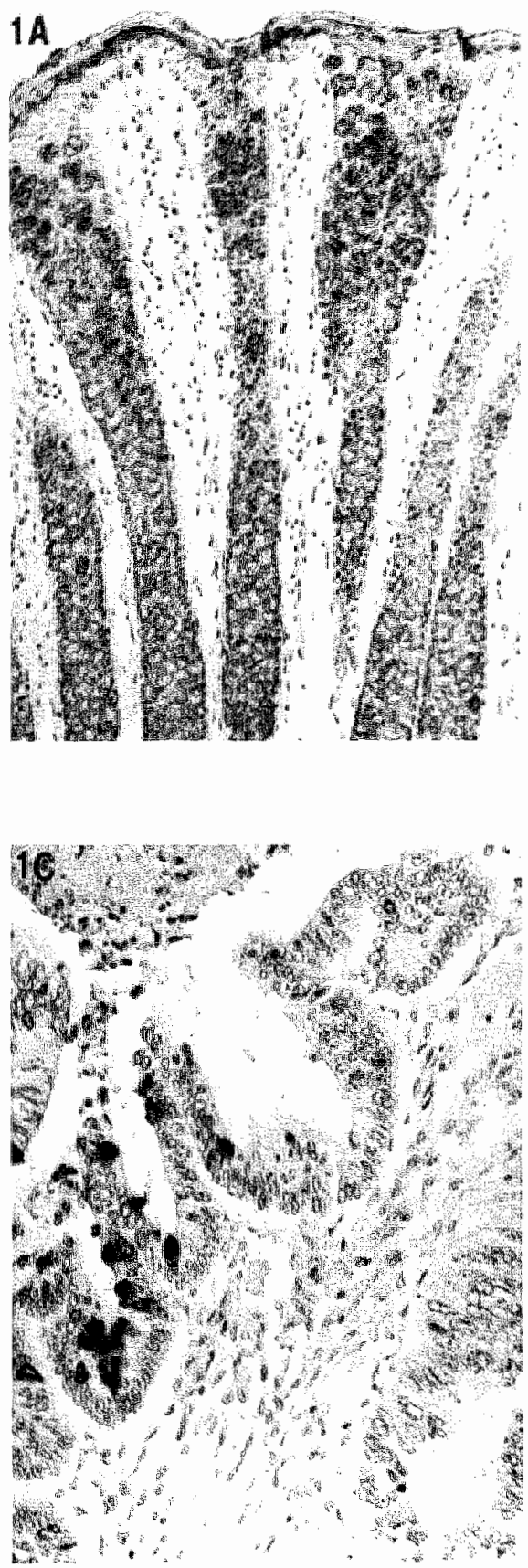

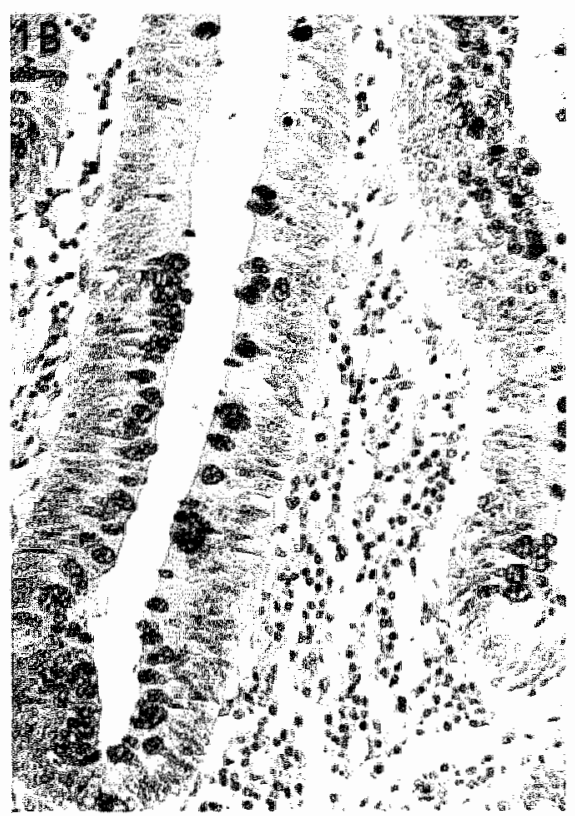

Figure 1. Representing immunoreactivity of PARLAM 3, 9 and 10 with normal and neoplastic colon.

A. Cytoplasmic goblet cell staining of PARLAM 10 in nomal colonic mucosa $(x 60)$.

B. Immunoreactivity of PARLAM 10 with a colonic adenoma. Only mucin vacuoles of mucin producing cells are positive (x150).

C. Staining pattem of PARLAM 10 on a colon cancinoma. Only a focal immunoreactivity is observed (x150). 


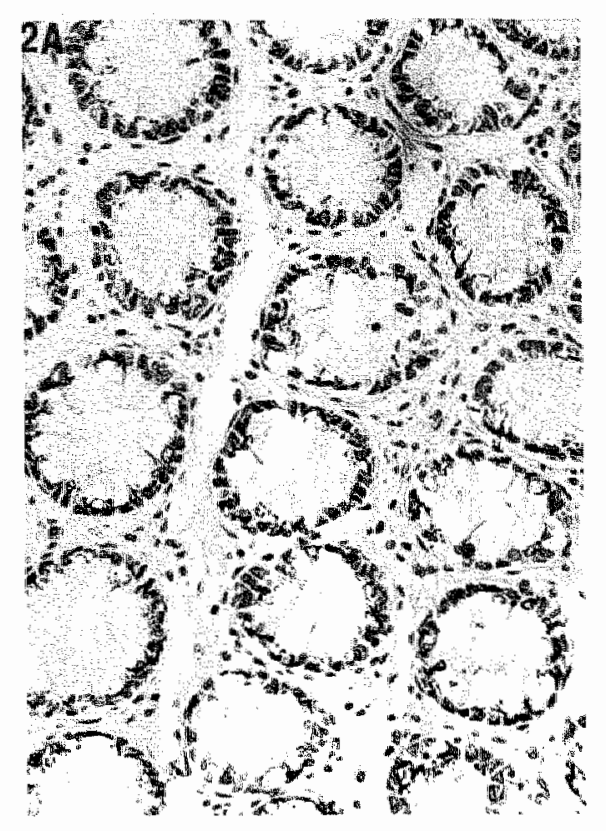

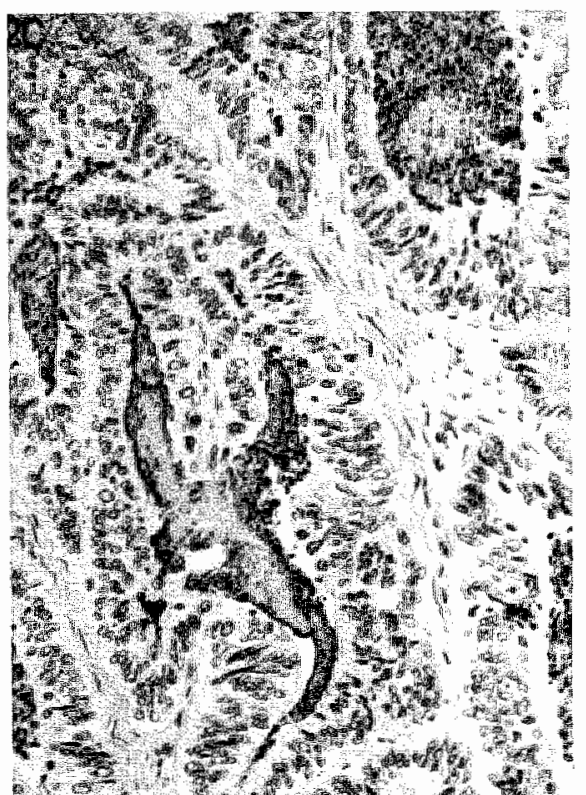

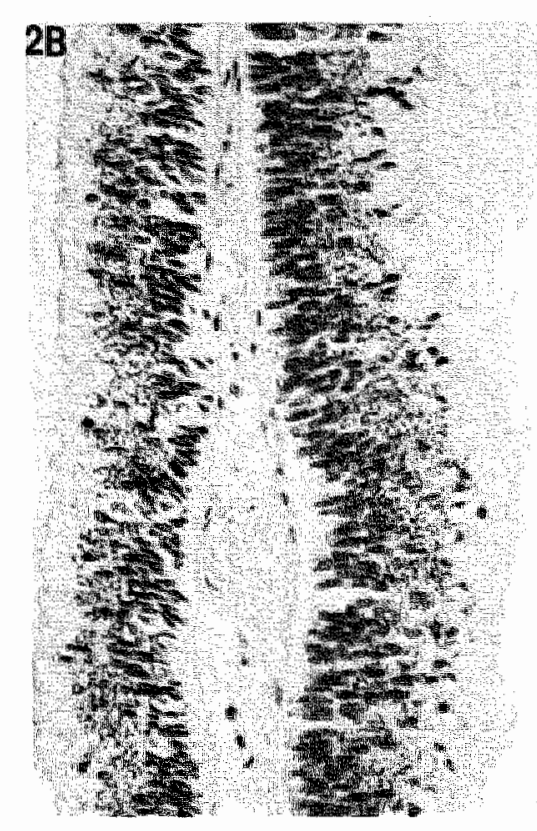

Figure 2. Representing immunoreactivity of PARLAM \&, 12 and 13 with nornal and neoplastic colon tissue.

A. Immunoreactivity of PARLAM 13 with nomal colon. The above the nucleus located cytoplasm in goblet cells is stained (X150). B. Immunoreactivity of PARLAM 13 with a colonic adenoma. More extended and more intense staining of the supranuclear cyloplasm is seen in the adenoma than in normal colon.

C. Immunoreactivity of PARLAM 13 on a colon carcinoma. In carcinoma often an apical and extracellular reactivity is seen. 


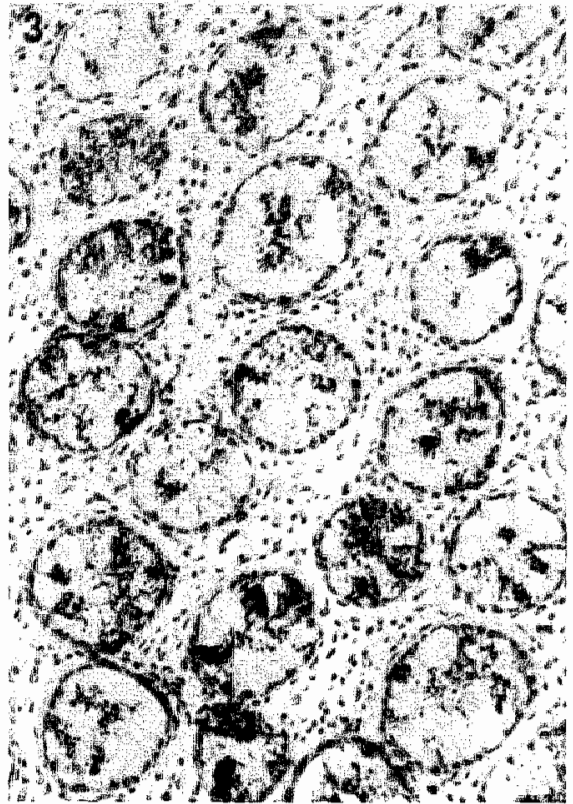

Figure 3. Focal, coarse granular staining of PARLAM 2 with normal colonic epitelium (x150).

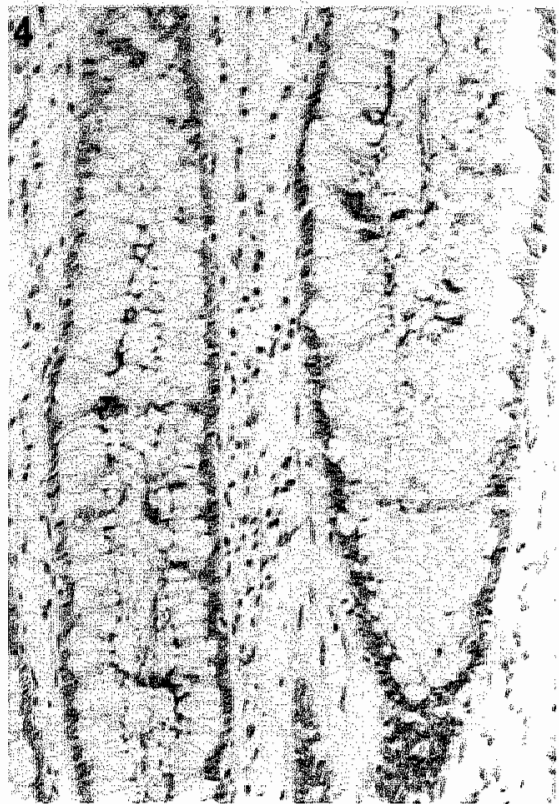

Figure 4. Apical staining of PARLAM 11 with normal colonic epithelium $(x 150)$.

Reactivity in extracolonic epithelia

The pattern of reactivity of our Mo Abs on various human tissues is listed in table II. In small intestinal mucosa most Mo Abs showed diffuse cytoplasmic staining of goblet cells. However, PARLAM 11 did not show any reactivity in the small intestine. Bile duct and gall bladder epithelium showed a variable extent of reactivity with the Mo Abs in the apical cytoplasm of mucin producing cells (Fig. 5). In the stomach mainly a diffuse cytoplasmic reactivity with gastric foveolae was found; gastric glands did not show any reactivity. Goblet cells of respiratory epithelia in the nasal cavity and bronchus (Fig. 6) reacted with most of the Mo Abs. Less reactivity was found with acinar cells in the prostate. The endocervical mucosa showed reactivity with PARLAM 9, 10, 11, 12 and 13. The endometrium showed occasional immunoreactivity, with PARLAM 3,9, 10 and 13 especially in the secretory phase. Other tissues (Table II) 


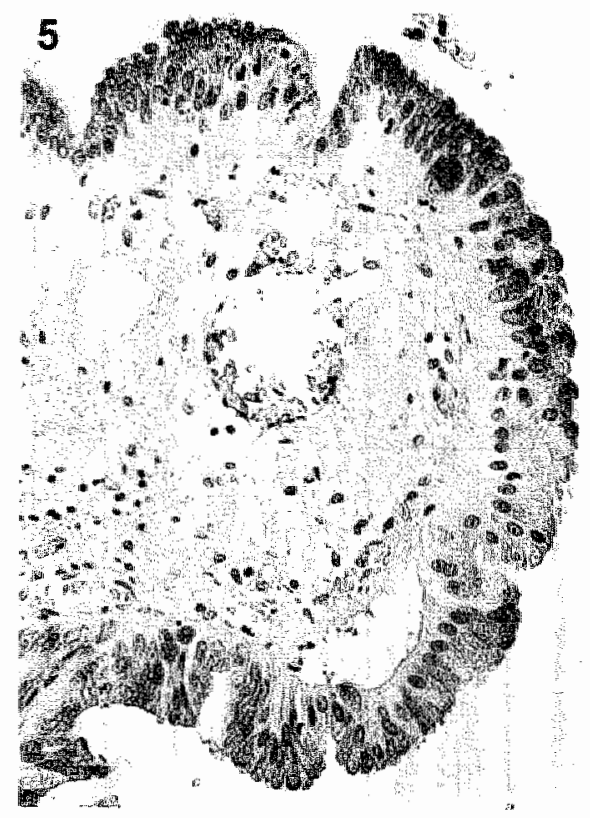

Figure 5. Reactivity of PARLAM 9 with gall bladder epithelium showing a focal apical cytoplasmic staining (xI50).

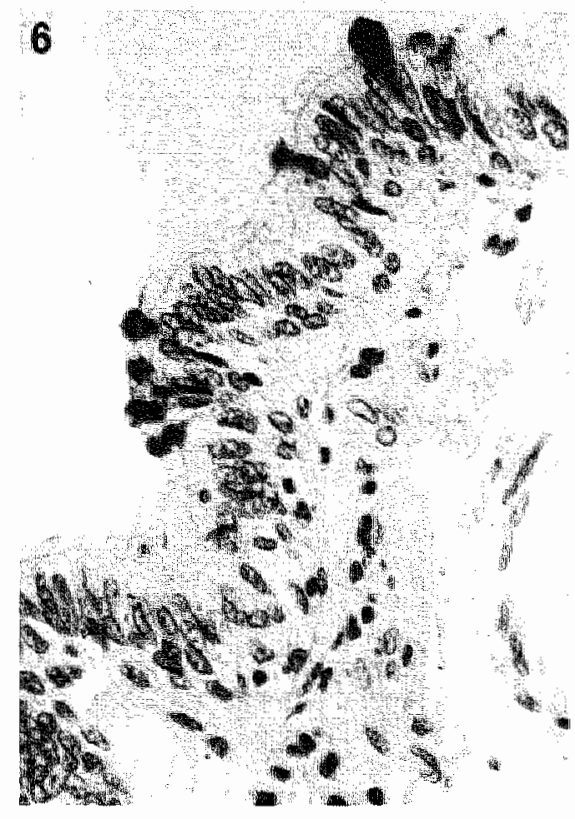

Figure 6. PARLAM 13 on bronchial epithelitum showing reactivity with mucin producing cells (x360).

reacted to a variable extent with PARLAM 2, 9, 10 and 13. Pancreas, kidney, adrenal gland, urinary bladder, epidermis, esophagus, thyroid, muscle, lymphnode, spleen and testis were entirely negative. It is clear therefore that our panel of Mo Abs almost exclusively reacts with mucin producing cells. Exceptions are PARLAM 9 and 10 which react with Hofbauer cells in the placenta, which are known to contain high molecular weight glycoproteins. Furthermore, PARLAM 2 and 13 appear to react with surface epithelial cells of ectocervix and esophagus. The Mo Abs PARLAM 2 and 12 occasionally bind to endothelium.

Fetal tissues

The results of testing on a panel of fetal tissues are shown in table III. PARLAM 9, 10 and 11 showed reactivity with fetal colonic 
Table II. Immunoreactivity of PARLAM monoclonal antibodies with normal human tissues.

\begin{tabular}{|c|c|c|c|c|c|c|c|c|}
\hline Group & & & I & & II & & III & IW \\
\hline PARLAM & $\mathrm{N}$ & 3 & $9 / 10$ & 8 & $\overline{12}$ & 13 & 2 & 11 \\
\hline $\begin{array}{l}\text { Colon } \\
\text { Smal1 intestine } \\
\text { Gal1 bladder } \\
\text { Stomach (*fovea stomach) }\end{array}$ & $\begin{array}{l}9 \\
3 \\
9 \\
7\end{array}$ & $\begin{array}{l}9 \\
3 \\
2 \\
0\end{array}$ & $\begin{array}{l}9 \\
3 \\
8 \\
6 *\end{array}$ & $\begin{array}{l}3 \\
- \\
-\end{array}$ & $\begin{array}{l}8 \\
2 \\
2 \\
0\end{array}$ & $\begin{array}{l}9 \\
3 \\
8 \\
4^{*}\end{array}$ & $\begin{array}{l}9 \\
3 \\
4 \\
4\end{array}$ & $\begin{array}{l}9 \\
- \\
7 \\
1\end{array}$ \\
\hline $\begin{array}{l}\text { Bronchi } \\
\text { Nasal mucosa } \\
\text { Prostate } \\
\text { Endocervix } \\
\text { Endometrium ('Early secretory phase) } \\
\text { Serous Salivary gland } \\
\text { Mamina ( lactating) } \\
\text { Mucous gland pancreas } \\
\text { Desophagus mucous gland } \\
\text { Sk in sweat gland } \\
\text { Ectocervix keratinizing cell borders } \\
\text { Desophagus keratinizing ce } 11 \text { borders } \\
\text { Placenta hofbauer cells }\end{array}$ & $\begin{array}{l}4 \\
4 \\
3 \\
3 \\
8 \\
1 \\
4 \\
3 \\
2 \\
4 \\
2 \\
3 \\
2\end{array}$ & $\begin{array}{l}2 \\
1 \\
1 \\
0 \\
1^{+} \\
- \\
- \\
- \\
- \\
\text {nt } \\
- \\
-\end{array}$ & $\begin{array}{l}4 \\
2 \\
1 \\
3 \\
1 \\
1 \\
1 / \\
1 / \\
2 \\
2 \\
4 \\
- \\
- \\
2\end{array}$ & $\begin{array}{l}2 \\
1 \\
3 \\
0 \\
- \\
- \\
1 \\
- \\
- \\
- \\
-\end{array}$ & $\begin{array}{l}- \\
1 \\
3 \\
0 \\
- \\
- \\
- \\
- \\
- \\
-\end{array}$ & $\begin{array}{l}4 \\
4 \\
3 \\
3 \\
1^{+} \\
1 \\
2 \\
2 \\
1 \\
2 \\
2 \\
3 \\
-\end{array}$ & $\begin{array}{c}4 \\
4 \\
3 \\
3 \\
5 \\
1 \\
2 \\
- \\
n t \\
2 \\
3 \\
-\end{array}$ & $\begin{array}{l}4 \\
3 \\
- \\
3 \\
- \\
1 \\
- \\
- \\
- \\
- \\
- \\
- \\
-\end{array}$ \\
\hline
\end{tabular}

mucosa of various stages of development. Reactivity of PARLAM $2,3,12$ and 13 and for colonic tissues was confined to mid to end gestation. PARLAM 2, 9, 10 and 13 consistently reacted with gobjet cells of fetal small intestinal mucosa. PARLAM 9, 10 and 13 also showed reactivity with the antral foveolae in the stomach.

\section{Colorectal adenoma and adenocarcinoma reactivity}

The reactivity of our Mo Abs with neoplastic colonic lesions is listed in table IV. In comparison with normal colon PARLAM 3, 9 and 10 showed decreasing immunoreactivity in adenomas and even more so in carcinomas (Fig. 1). In contrast, reactivity with PARLAM 8, 12 and 13 increased in adenomas and carcinomas (Fig. 2). Also the pattern of immunoreactivity altered. The limited supranuclear and cytoplasmic reactivity in normal colon (Fig. 2A) changed to intense supranuclear staining in adenomas (Fig. 2B). In carcinomas apical and diffuse cytoplasmic staining was observed (Fig. 2C). 
Table III. Staining of the Mo Abs with fetal and newborn tissue.

\begin{tabular}{|c|c|c|c|c|}
\hline Mo $\mathrm{Ab}$ & Organ & mid gestation & $\begin{array}{l}\text { Presence in } \\
\text { late gestation }\end{array}$ & newborn \\
\hline 3 & $\begin{array}{l}\text { Collon } \\
\text { Smiall intestine } \\
\text { Stomach }\end{array}$ & $\begin{array}{l}- \\
-\end{array}$ & $\begin{array}{l}+ \\
-\end{array}$ & $\begin{array}{l}+ \\
+ \\
-\end{array}$ \\
\hline $9 / 10$ & $\begin{array}{l}\text { Colon } \\
\text { Sma } 11 \text { intest ine } \\
\text { Stomach }\end{array}$ & $\begin{array}{l}+ \\
+ \\
+\end{array}$ & $\begin{array}{l}+ \\
+ \\
+\end{array}$ & $\begin{array}{l}+ \\
+ \\
+\end{array}$ \\
\hline 8 & $\begin{array}{l}\text { Colon } \\
\text { Sma } 11 \text { intestine } \\
\text { Stomach }\end{array}$ & $\begin{array}{l}+ \text { - } \\
+ \text { and - } \\
+ \text { and - }\end{array}$ & - & $\begin{array}{l}- \\
-\end{array}$ \\
\hline 12 & $\begin{array}{l}\text { Colon } \\
\text { Small intestine } \\
\text { Stomach }\end{array}$ & $\begin{array}{l}+ \\
-\end{array}$ & $\begin{array}{c}+ \text { and - } \\
+ \text { and - } \\
-\end{array}$ & $\begin{array}{l}- \\
-\end{array}$ \\
\hline 13 & $\begin{array}{l}\text { Colon } \\
\text { Sma11 intestine } \\
\text { Stomach }\end{array}$ & $\begin{array}{l}+ \\
+ \\
+\end{array}$ & $\begin{array}{c}+\quad \text { and - } \\
+ \\
+\end{array}$ & $\begin{array}{l}- \\
+ \\
+\end{array}$ \\
\hline 2 & $\begin{array}{l}\text { Colon } \\
\text { Sma11 intestine } \\
\text { Stomach }\end{array}$ & $\begin{array}{l}+ \text { and - } \\
+ \\
+\end{array}$ & $\begin{array}{l}- \\
+\end{array}$ & $\begin{array}{l}- \\
+ \\
-\end{array}$ \\
\hline 11 & $\begin{array}{l}\text { Colon } \\
\text { Small intestine } \\
\text { Stomach }\end{array}$ & $\begin{array}{l}+ \\
- \\
-\end{array}$ & + & $\begin{array}{l}+ \\
- \\
-\end{array}$ \\
\hline $\begin{array}{l}+ \\
+ \text { and } \\
-\end{array}$ & $\begin{array}{l}=\text { present in } \\
=\text { present in } \\
=\text { present in }\end{array}$ & $\begin{array}{l}-100 \% \text { of the } \\
\text { out } 25-75 \% \text { of } \\
\text { s than } 25 \% \text { of }\end{array}$ & $\begin{array}{l}\text { imen tested } \\
\text { cases tested } \\
\text { specimen test }\end{array}$ & \\
\hline
\end{tabular}

The number of tissues with immunoreactive cells as well as the extent of immunoreactivity in a given neoplasm tended to diminish in comparison with adenomas. The proportion of reactive specimens for PARLAM 2 and 11 was similar in normal mucosa, adenomas and carcinomas. In adenomas and carcinomas PARLAM 2 staining was focal cytoplasmic as well as apical. PARLAM 11 predominantly 
Table $N$. Immunoreactivity of the various monoclonal antibodies (percentage of the number of cases tested) in colonic, normal mucosa, adenoma and carcinoma.

\begin{tabular}{l|rr|rrrr|r|r|}
\hline Group & & $\mathbb{I}$ & \multicolumn{3}{|c|}{ II } & & III & IV \\
\hline PARLAM & 3 & $9 / 10$ & 8 & 12 & 13 & 2 & 11 \\
\hline Normal colon $(n=9)$ & 100 & 100 & $\star 33(33)$ & $77(44)$ & $66(44)$ & 66 & 88 \\
Adenoma $(n=10)$ & 70 & 90 & $60(60)$ & $80(80)$ & $100(90)$ & 90 & 70 \\
Carcinoma $(n=13)$ & 46 & 46 & $61(0)$ & $46(0)$ & $69(0)$ & 77 & 77 \\
\hline
\end{tabular}

Between brackets the percentage of specimen with supranuclear staining.
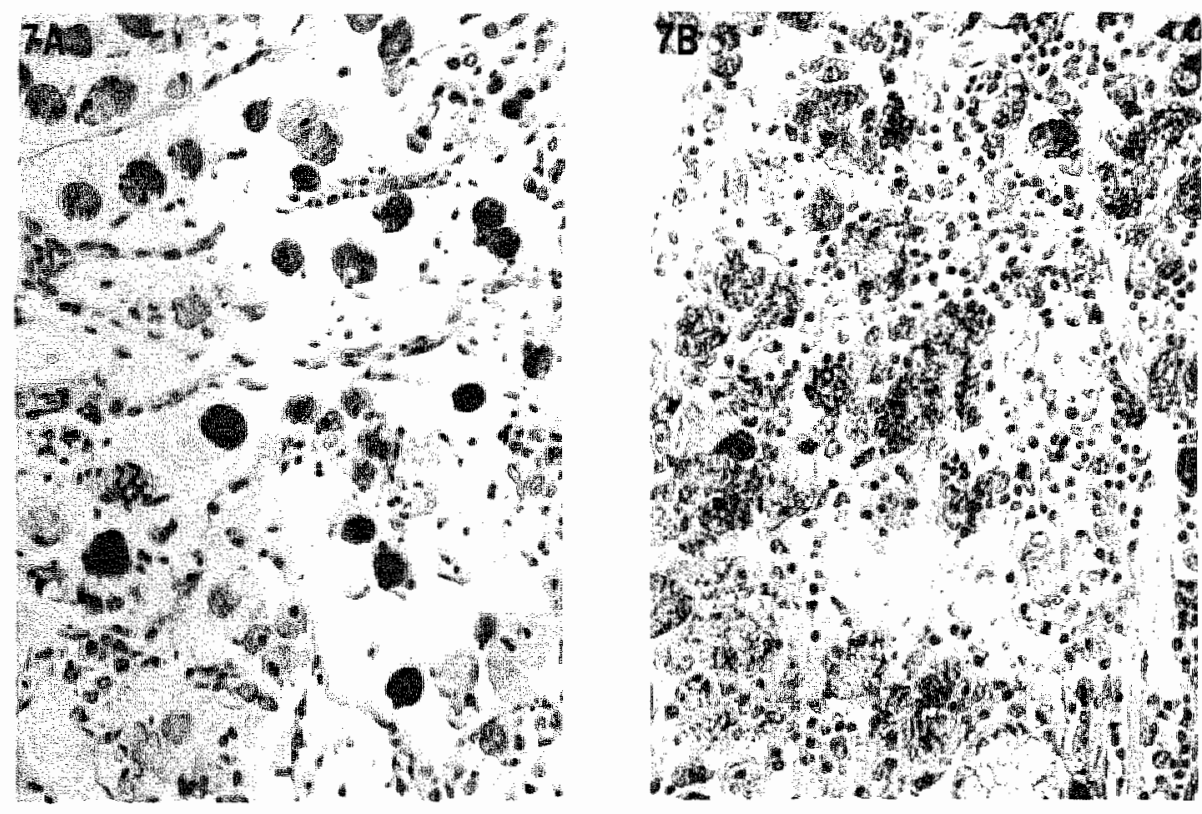

Figure 7. Reactivity of PARLAM 9 (7A) and 13 (7B) on a signetring cell carcinoma of the stomach (x150). 
Table V. Immunoreactivity of monoclonal antibodies with various neoplastic, human tissues.

\begin{tabular}{lr|rr|rrr|r|r|}
\hline Group & & & $I$ & & II & & III & IV \\
\hline PARLAM & $N$ & 3 & $9 / 10$ & 8 & 12 & 13 & 2 & 11 \\
\hline Colan adenoma & 10 & 7 & 9 & 6 & 8 & 10 & 9 & 7 \\
Colon carcinoma & 13 & 6 & 6 & 8 & 6 & 9 & 10 & 10 \\
Stomach carcinoma & 6 & 2 & 2 & 3 & 0 & 4 & 5 & 5 \\
Intest inal metaplasia stomach & 3 & 1 & 3 & 1 & 1 & 2 & 2 & 0 \\
Gall bladder carcinoma & 2 & 1 & 1 & 0 & 1 & 1 & 1 & 1 \\
Lung adenocarcinoma & 4 & $n t$ & 1 & 3 & 2 & 4 & $n t$ & 2 \\
Endometrium carcinoma & 9 & 0 & 3 & 1 & 0 & 7 & 9 & 3 \\
Mucinous cyst adenoma ovary & 4 & 2 & 2 & 1 & 0 & 2 & 3 & 0 \\
Serous cyst adenoma ovary & 1 & 0 & 0 & 0 & 0 & 0 & 0 & 1 \\
Mastopathy & 6 & 0 & 2 & 2 & 0 & 2 & 2 & 0 \\
Ductal mamma carcinoma & 4 & 0 & 1 & 1 & 0 & 2 & 0 & 0 \\
Lobular mamma carcinoma & 2 & 0 & 0 & 2 & 0 & 2 & 0 & 1 \\
Salivary gland carcinoma & 4 & 0 & 0 & 3 & 0 & 2 & 0 & 0 \\
Lung squamous cell carcinoma & 4 & 0 & 0 & 0 & 0 & 3 & 2 & 0 \\
& & & & & & & & \\
\hline
\end{tabular}

showed an apical membranous reactivity. All tested colloid carcinomas reacted with all Mo Abs.

Distribution of immunoreactivity in other carcinomas

Immunoreactivity of our Mo Abs appeared not to be restricted to colonic neoplasms (Table V). Most Mo Abs also reacted with carcinomas of the stomach and gall bladder. All Mo Abs showed reactivity with a signetring cell carcinoma of the stomach (Fig. 7). Goblet cells in adenocarcinomas of the lung also demonstrated consistent immunoreactivity. Mucinous cystadenomas of the ovary and cystadenocarcinomas and endometrium carcinomas also showed local immunoreactivity with most of the Mo Abs. Other carcinomas were negative (Table $v$ ).

\subsection{Discussion}

The results presented in this study demonstrate that our monoclonal antibodies identify epitopes on mucin antigens, especially in goblet cells. Also, they show an expression pattern which is largely restric 
ted to epithelia of endodermal derivation. PARLAM 8 reacted only with a minority of normal colon specimens and not at all with small intestinal mucosa. PARLAM 11 reacted with brushborders of columnar cells in collonic mucosa but not with columnar cells in the small intestine. The other monoclonal antibodies reacted with all colon and most small intestinal specimens. Variable patterns of reactivity were found for the various monoclonal antibodies with other endodermal tissues. Outside the endodermally derived epithelia only limited reactivity occurred. Notable exceptions were isolated prostatic glands (possibly corresponding to the utriculus), endocervix and endometrium, all derived from the Mullerian duct. This pattern of expression was also reported for M1 antigens of gastric mucosa (13). For glycoprotein reactive antibodies the possibility that they react with epitopes related to bloodgroup antigens must be excluded (14). Comparison of the staining patterns of our monoclonal antibodies of those of the ABH and Lewis bloodgroup antigens, however, made that possibility unlikely $(15,16)$ with exception of PARLAM 12 which occasionally reacted with vascular endothelium and other stromall components. Furthermore, Lewis A and Lewis B antigens have a lower molecular weight than we found for the PARLAM antigens (17).

It is conceivable that incomplete or altered glycosylation of mucins occurs in neoplastic colonic mucosa as compared to normal epithelium. Studies with conventional mucin histochemistry have indeed indicated that the type of mucin produced in normal epithelium, adenomas and carcinomas may be different (18-20). The results of conventional mucin histochemistry, however, are variable and may depend on the exact conditions of the staining protocols used. Specificity of lectin binding patterns may be a problem as well, since the carbohydrate sequences detected by lectins may reside on biochemically unrelated molecules. Immunohistochemistry, therefore, may be of value to determine the type of mucin produced in colonic epithelium under various pathological conditions. Monoclonal antibodies could potentially even probe mucin molecules with altered patterns of glycosylation.

The group II monoclonal antibodies PARLAM 8, 12 and 13, may be of value to study the qualitative alterations of mucin synthesis accompanying neoplastic transformation, especially in the colon. The epitopes reacting with these monoclonal antibodies are associated with the carbohydrate component of mucin molecules and our immunohistochenical data suggest that these monoclonal antibodies might 
react with glycoproteins in different phases of posttranslational processing. The predominant localization of the target epitopes of PARLAM 8, 12 and 13 in the supranuclear regions of goblet cells, which corresponds to the Golgi complex supports this contention. Peanut agglutinin, Vicia villosa agglutinin and Griffonia simplicifolia II agglutinin also show Golgi complex restricted reactivity (21). For these lectins galactosamine and $\mathrm{N}$-acetylgalactosamine are the binding carbohydrate residues and these residues also occur in the target epitopes of our monoclonal antibodies. We postulate that our monoclonal antibodies might recognize related molecular structures. These might be mucins in the early phase of glycosylation in the Golgi complex. Furthermore, the PARLAM 8, 12 and 13 antigens are expressed in colon and/or small intestine only during early developmental stages. Similar observations were also reported for M1 and M3 antigen (22).

The monoclonal antibodies of Group I, PARLAM 3, 9 and 10, were shown to react with an epitope residing on the protein component of the mucin molecule (11). Since the monoclonal antibodies demonstrate a similar reaction pattern with most normal goblet cells of different tissue sources, it must be assumed that the core proteins of most mucins show extensive homology or at least contain structurally related domains on which the epitopes, recognized by our monoclonal antibodies occur. Our data also show that this part of the mucin molecule appears rather late during embryonal development: in the last trimester of gestation. The decrease of reactivity observed in neoplastic colonic mucosa probably merely reflects loss of the ability to synthesize mucin in adenomas of increasing atypia and non-mucinous carcinomas. A similar phenomenon was noted by Hughes (7) and Richman and Bodmer (9). These authors studied the expression of normal colon mucosal antigens in colonic adenomas and carcinomas and found decreased and heterogeneous expression in adenomas and carcinomas, some of which were completely negative.

The antigen of PARLAM 12 was the only one of the series observed in stromal components and therefore may be bloodgroup related. The reaction pattern of the PARLAM 2 antigen appeared 10 be inconsistent and difficuit to interpret. PARLAM 11 showed reactivity with the apical plasma membrane of columnar cells. As the PARLAM 11 antigen is of high molecular weight and can be extracted with PCA it may nevertheless be regarded as a mucin antigen. This monoclonal antibody may be of particular interest for the study of differentiation of normal colonic mucosa, in that it appears 
to react with a brushborder associated antigen present in colonic, but not in small intestinal and gastric mucosa.

In summary, we have generated a panel of monoclonal antibodies directed against human high molecular weight glycoproteins, largely restricted to epithelia of endodermal derivation. Antigens of PARLAM 3,9 and 10 show a decreased expression in colonic adenomas and carcinomas and appear to be useful for the study of goblet cell differentiation and of the biological and clinical significance of goblet cell differentiation in neoplastic colonic mucosa. Antigens of PARLAM 8, 12 and 13 show an increased expression in neoplastic colonic mucosa and appear to be of value for investigations concerning the occurrence and significance of alterations in mucin production accompanying the early development of the malignant phenotype in colonic epithelium. We are currently investigating whether the expression of these antigens in normal colonic mucosa could be correlated with a higher chance of development of metachronic adenoma and whether expression in adenomas correlates with a higher chance of development of carcinoma. 


\section{References}

1. Seplewski Z, Koprowski H. Monoclonal antibody dewelopment in the siudy of colorectal carcinoma-associated antigens. Methods in cancer research 1982, 20: 285-316.

2. Finan PJ, Grant RM, De Mattos C, Takei F, Benty PJ, Lemox ES, Bleehen NM. Immunohistochemical techuigues in the early screening of monodonal antibodies to human colonic epithelium. Br. J. Cancer 1982, 46: 9-17.

3. Thompson $\mathrm{CH}$, Jones SL, Pilial E, Mckenzie UFC Monodonal antibodies to hunan colon and colorectal carcinoma. Br. J. Cancer 1983, 47. 595-605.

4. Morgan $A C_{w}$ Woodhouse $C S$, Knost JA, Abrams $P G$, Charke GC, Arthur LO, Malatyre $\mathbb{R}$, Ochs JJ, Foon KA, Oldham $\mathbb{R K}$. Monocional amtibodics to buman coloracal numor-assoctated ankigens: improved eliciation and subclass restriction. Hybridoma 1984, 3: 233.265

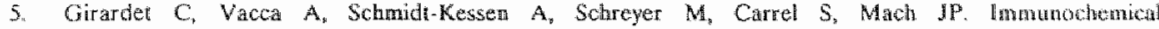
characterization of two antigens recognized by new monoclonal antbodies aigaimst buman colon carcinoma. J. Immunol. 1986, 136: 1497-1503.

6. Drewinko $B_{n}$ Yasg LY', Chan J, Trujillo JM. New monoclona anatibodies angainst colon cancerassociated antigens. Cancer Res. 1986, 46: 5137-5143.

7. Hughes $\mathrm{NR}_{\text {, Walls }} \mathrm{RS}$. Newland RC, Payne JE. Antigen expression in normal and neoplastic colonic mucosa: three tissue-specific anigens using nonoclonat antibodies to iscolated colonic glands. Cancer Res. 1986, 46: 2164-2171.

8. Podolsky DK, Foumier DA, Lymob KE. Development of anti-human colonic nucin monoclonal antitbodies. Characterization of multiple colonic mucin species. I. Clin. Invest. 1986, 77: $1251-1,262$.

9. Richman Pl, Bodmer WF. Monoclonal antibodies to human colorectal pilhelium: narkers for differentiation and tumor characterization. Int.. J. Cancer 1987, 39. 317-328.

10. Podolsky DK, Fournier DA, Lynch KE. Hinnan colonic gotblet cells, Demonstration of distinct subpopulations defined by mucin-specific monodonal amibodics. J. Clin. Invest. 1956. 77 $1263 \times] 271$.

11. Verstijnen CPHJ, Areads JW, Moerkerk PTM, Bosman FT. Monoclonal antibody defined mucin antigens of normal and neoplastic buman colonic mucosa biochemical and histochemient characterization. (submifted).

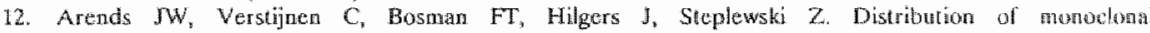
artibody-defined monosialoganglioside in normal and cancerous human tissues: An immunoperoxidiase study. Hybridona 1983,2 2: 219-229.

13. Bara $J$, Gavtier $R$, Daher $N$, Zaghouani $H$, Decaens $C$. Monoclonal antibodies against tancoletal mucin M1 antigens associated with precancerous colonic mucosae. Cancer Res. 1986,46: 3983-3989.

14. Feini T. Carbohydrate antigens in human cancer. Cancer Surv. 1985, 4: $245-269$

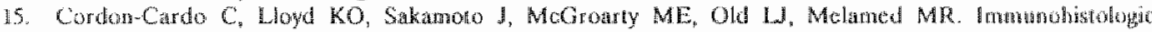
expression of bloodgroup antigens in normal human gastrointestinal tract and coloric carcinoma. Int. J. Ciancer 3986, 37: $667-676$.

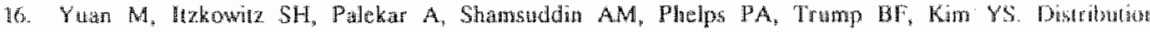

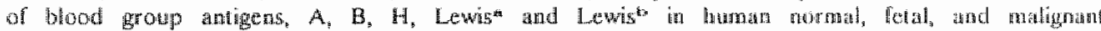
colonic lissue. Cancer Res. 1985, 45: 4499-4511.

17. Blaszezyk M, Pak KY, Herlyn M, Sears HF, Seplewski Z Chanachization of Lewis antigers in normal colon and gastrointestinal adenocarcinomas, Proc. Nath. Acand. Sici. USA, Was, 82: $3552-3550$.

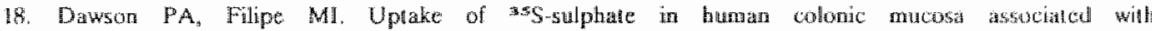
carcinoma: an autoradiographic analysis at the whastructurall fovel. Histochem. J. 1983, 13: 313

19. Shamsuddin AKM. Weiss L, Phelps PC, Trump BF. Colon cpithelim. IV. Hunan colon carcinogenesis. Changes in buman colon mucosit adjacent to sand remote from curcinomats of the colon. INACI 1981, 60: 413-419.

20. Bolund CR, Montgomery CK, Kim YS. Allerations in human colonic mucian oucurring with

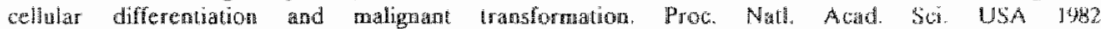
79: $2051-2055$.

21. Kellokurnpu 1, Kath $K$ Andersson LC. Lectin-binding sites in turmat, byperplastic, adenomathus and carcinomatous buman colorectal mecosa. Acta Path. Microbiol. Immunol. Scand. Sect. A. $1986,94: 271-280$.

22. Bara J, Burtin P. Mucus-associated gastrointestinal antigens in transilional mucosa adjacent to human colonic adenocarcinonas: their tetal-type association. Eur. J. Cancer 1980, 16: $1311-1114$ 
MODEL STUDIES IN COLORECTAL CANCER 


\section{INTRODUCTION}

As was discussed in chapter 1 . analysis of aspects of morphology and/or differentiation of cancer tissues, derived from resected specimens, presents only a momentous view on these aspects of tumor biology. Many characteristics of tumor cells , however, can only be analyzed in time. Important characteristics, such as cell kinetics and the process of differentiation, are time related and cannot be successfully studied in human tumor material. Therefore, many model systems have been developed, which allow the study of these characteristics on a time scale and in conditions which can be manipulated. The most important of these model systems are tissue culture and nucle mouse xenografting. This chapter discusses a number of aspects of the development of these model systems in colorectal cancer studies.

It has become clear that in neoplasms patterns of differentiation occur which reflect patterns of differentiation in the corresponding normal tissue. Therefore, for the development of biologically relevant classification systems, precise knowledge of the pathways of normal differentiation is essential. For colonic mucosa the body of knowledge concerning the differentiation from stem cells to mature enterocytes is still rather limited. What notoriously lacks is a model system in which various cellular characteristics can be studied in their development in time. We have attempted to xenograft normal colonic mucosa in nude mice, in order to obtain a model system for the study of differentiation of colonic mucosa in vivo. The results of these attempts are described in III.2.

It is clear that in order to yield relevant information, model systems must reflect the in vivo situation in the neoplasm to reasonable extent. In IIII.3 we have analyzed the characteristics of colonic cancer xenografts and cell cultures in comparison with the characteristics of primary tumor cells, derived directly from resected tumor material. It will be shown in this chapter that these model studies indeed rather closely parallel the human situation and therefore are a most valid tool in the study of human tumor biology.

In III.4 this aspect is discussed in depth in the description of two new colonic cancer cellines, which were obtained from one human colonic carcinoma. This illustrates the problem of tumor heterogeneity by demonstrating that these cellines were genetically and phenotypically different. 


\section{XENOGRAFTING OF NORMAL COLONIC MUCOSA IN ATHYMIC MICE.}

\subsection{Introduction}

Intestinal mucosa is an actively proliferating tissue in which cell renewal only takes about two days (1). In this period undifferentiated progenitor cells proliferate and maturate to at least three differentiated cell types: goblet cells, columnar cells and neuroendocrine cells. At present the most widely held view concerning the origin of the various colonic epithelial cell types is the unitarian theory (2), which postulates that all epithelial cell types are derived from one precursor cell, the crypt base stem cell. Direct proof for this theory is still incomplete and discrete steps in the differentiation of intestinal epithelial cells have not been recognized.

So far intestinal epithelial differentiation has been mainly studied in vitro. Methods for organ culture of normal colon mucosa have been developed and colon mucosa can be cultured up to 3 to 4 weeks $(3,4)$. However, in vitro systems remain more artificiall than those in vivo and do not allow analysis of the interaction of various tissue elements. Furthermore, in in vivo models conceivably cellular growth and differentiation might be modulated also $(5,6,7)$. We therefore attempted to establish an in vivo model of colonic epithelial differentiation by xenografting fragments of colon mucosa subcutaneously into nude mice. The aim of the present study was to describe the histologic and immunocytochemical characteristics of human colon mucosa transplanted into nude mice and to establish the proliferating and differentiating capacity of the xenografted colonic epithelium.

\subsection{Materials and methods}

\section{Animals}

Balb/c nu/nu mice (supplied by TNO, Rijswijk, The Netherlands), NMRI nu/nu mice (supplied by Zentral Institut fur Versuchstiere, 
Hannover, Germany) and CD-1 nu/nu mice (supplied by Charles River WIGA, Sulzfeld, Germany) were housed in laminar flow cabinets in an SPF unit. The animals were kept separately or by two in open polypropylene cages at a temperature of 26 to $28^{\circ} \mathrm{C}$.

The animals were fed with standard pellets and tap water ad libitum. Cages, bedding, drinking bottles and water were sterilized by autoclaving and pellets by irradiation. Nude mice were consistently handled using aseptic methods.

\section{Tissues}

Mouse fetal intestine was obtained from Wistar mice at day 17 of gestation. The fetal intestines were removed under sterile conditions and washed in a petridish in phosphate buffered saline (PBS). Samples were also processed for histological examination. Fetal tissues were implanted within 30 minutes after excision.

Normal human colonic mucosa was obtained from colectomy specimens of 5 patients with colonic adenocarcinoma. As soon as possible after resection, mucosa with a normal appearance at a distance of at least $10 \mathrm{~cm}$ from the tumor, was carefully dissected from the muscularis propria and put in PBS. Further processing was done in a laminar flow cabinet. To eliminate normal colonic bacterial flora as much as possible, $2 \times 2 \mathrm{~cm}^{2}$ mucosal fragments were washed gently in excess PBS and adherent mucus was removed by gentle scraping of the mucosal surface with a rubber policeman. The central $1 \mathrm{~cm}^{2}$ part was then excised, and washed again in PBS. Human colonic mucosa was implanted within 90 minutes after resection. PBS contained $200 \mu \mathrm{gr} / \mathrm{ml}$ penicillin and $200 \mu \mathrm{gr} / \mathrm{ml}$ streptomycin.

\section{Transplantation}

The grafting procedure was performed in a laminar flow cabinet under ether anesthesia. Fetal mouse intestinal tissues and human colonic mucosa were cut in small pieces $\left( \pm 1 \mathrm{~mm}^{3}\right)$ immediately before implantation. Each mouse received 4 tissue fragments. Incisions were made with a pair of scissors and with a pair of blunt forceps a small pocket was prepared subcutaneously in which a tissue fragment was applied. The incisions were sutured with two nylon stitches.

\section{Histology}

Animals were sacrificed after various time intervals by cervical dislocation. The xenografts were excised, fixed in formalin and embedded in paraffin. Mucin production was detected by staining 
with PAS and high iron diamine-alcian blue (HIDAB) (8). Neuroendocrine cells were detected by silver staining according to Grimelius (9) and by immunocytochemical detection of serotonin. Production of carcinoembryonic antigen (CEA) and secretory component (SC) by human colon epithelia was detected by immunocytochemistry. All immunocytochemical procedures were performed as described previously (10).

\section{Cell proliferation}

Proliferative activity in the xenografts was studied by BrdU incorporation. Four hours before sacrificing the animals received an intraperitoneal injection of Bromo-deoxy-Uridine $(\mathrm{BrdU}, 5 \mathrm{mg} / \mathrm{kg}$ bodyweight). BrdU incorporation was visualized by an indirect immunoperoxidase staining procedure as described previously (11).

\subsection{Results}

In order to test the feasibility of mucosa grafting, fragments of mouse fetal intestine were implanted in a congenic system. These attempts were successful from the start with $100 \%$ of the grafts surviving. After one week the grafts showed small intestinal mucosa with crypts and rather blunt villi. Numerous BrdU labelled cells substantiated the proliferative capacity of the grafted epithelium. When compared to non-grafted tissue the crypts and villi were less well developed (fig. nr. $1 \mathrm{~A}$ and $1 \mathrm{~B}$ ) but the epithelium showed more extensive differentiation with higher numbers of goblet cells and enterochromaffin cells. The goblet cells contained sulpho- as well as sialomucins.

The reaction of the various nude mouse strains to the human colo$n$ mucosa xenografts differed remarkably (Table 1 ). Of the xenografts in $\mathrm{Balb} / \mathrm{c}$ mice, about $60 \%$ ( 7 out of 12) resulted in abscess formation at the site of the xenograft within one week. Only about $40 \%$ (5 out of 12) of the xenografts in the NMRI mice showed this phenomenon and also at a later stage (app. 3 weeks). Abscess formation presumably was caused by bacterial contamination of the grafts, which we found difficult to avoid completely. Abscess formation led to destruction of the xenograft and caused wasting disease (WD). This occurred in $25 \%$ of the NMRI and even $50 \%$ of the Balb/c mice. In contrast, $\mathrm{CD}-1$ mice never showed abscess formation or WD. 

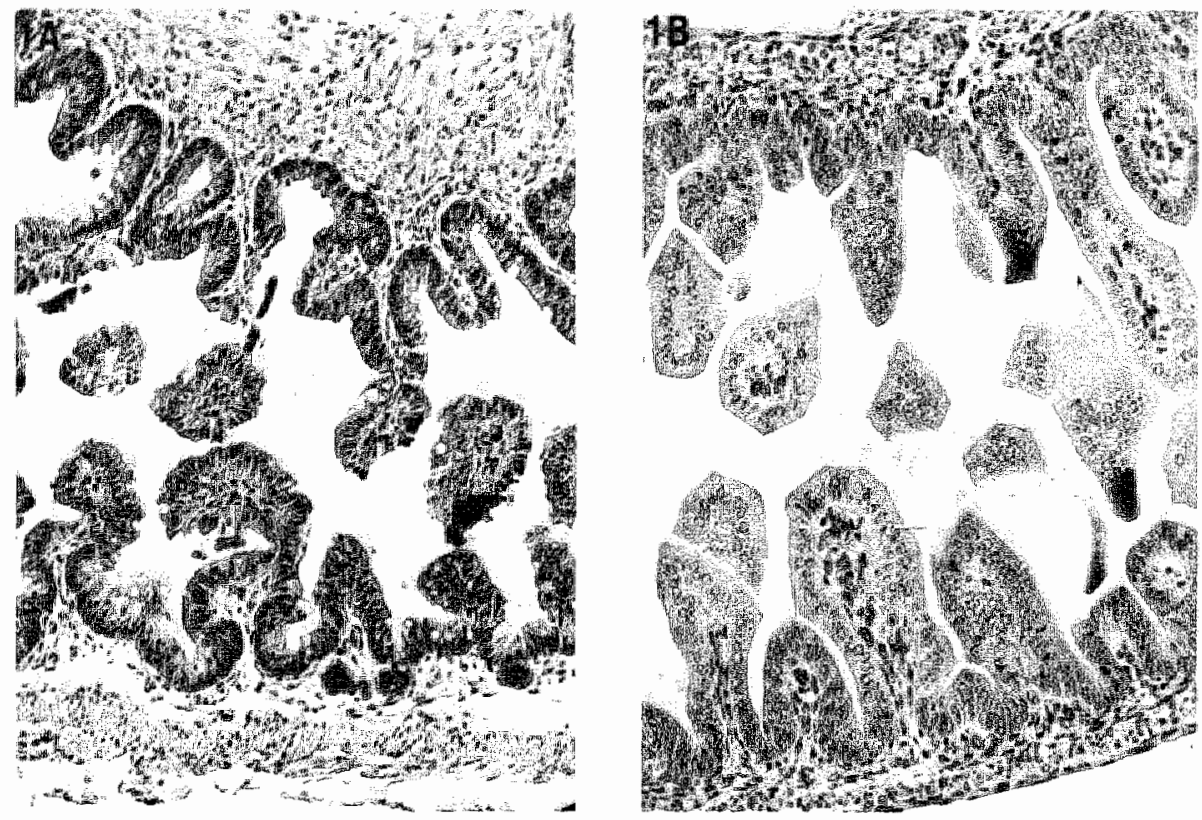

Figure 1. Comparison of grafted (LA) and nongrafted (1B) intestine of a 17 day mouse fetus. The xenograft contains more irregular and blunt shaped villi.

Overall, of 59 xenografted fragments of mucosa 12 were lost due to development of abscesses and 12 others did not contain epithelium anymore but only vital connective tissue. The remaining 35 xenografts showed, after a maximum of 5 weeks, vital epithelial cells . Table I lists in the different nude mouse strains, the fate and the histological characteristics of the xenografts at various time intervals. Due to the high probability of abscess formation the experiments in $\mathrm{Balb} / \mathrm{c}$ and NMRI mice were discontinued. In Balb/c mice the xenografts were not followed for more than two weeks. In this period of time four xenografts (2 after 1 and 2 after 2 weeks) displayed epithelial structures, only one containing extensive epithelial structures with crypt formation (fig. 2). Xenografts in NMRI mice were studied after 2 and 5 weeks. Only one of the xenografts at two weeks contained extensive epithelial structures.

The highest successrate occurred in CD-1 mice. Of 35 xenografts 
Table I. Xenograft histology at various time intervals.

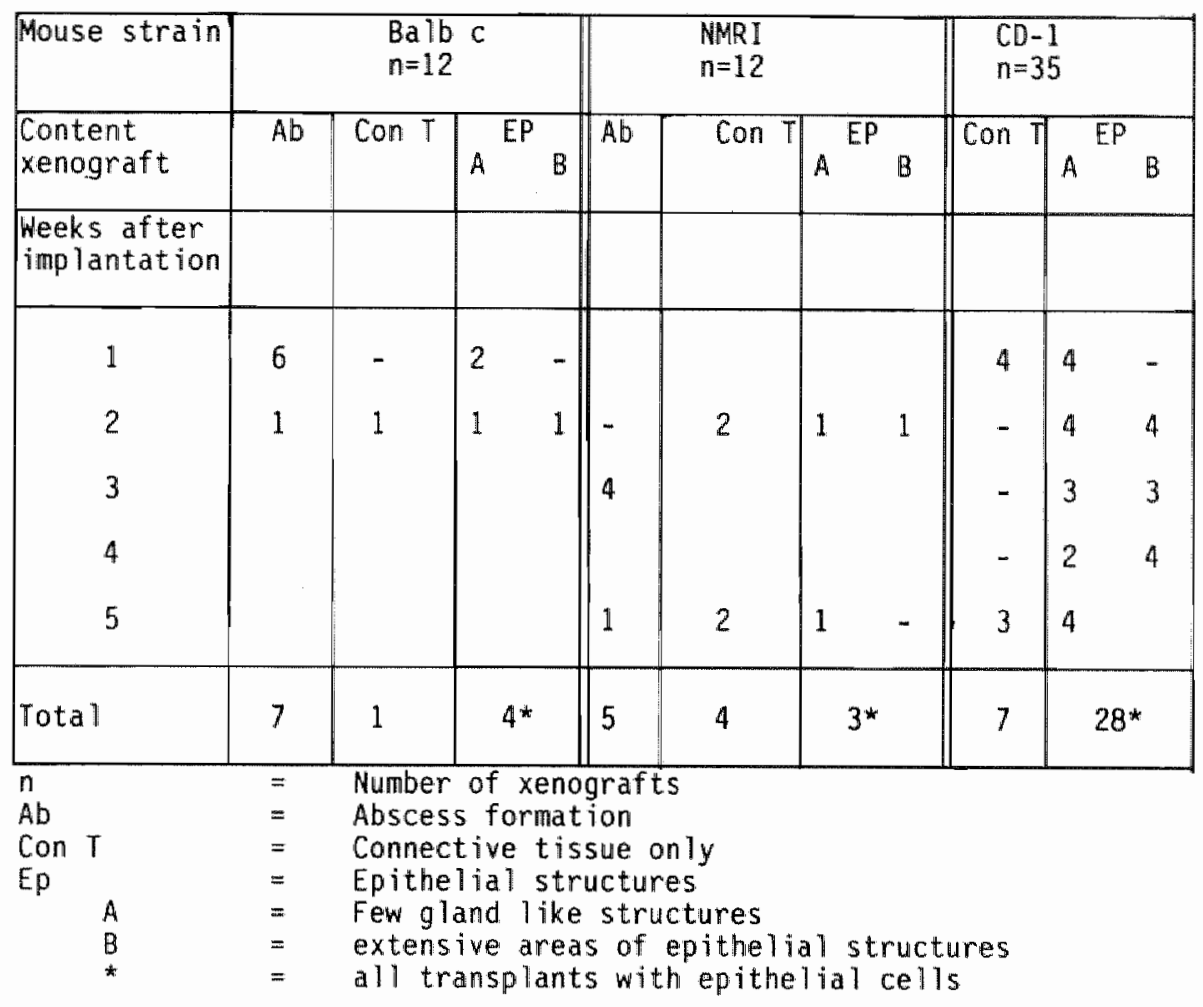

28 yielded epithelial structures. The histological development in time was rather characteristic. After one week the superficial crypt segments showed degenerated epithelial cells, only in the crypt basis vital epithelial cells were seen (Fig. 3A). In weeks 2 and 3 gradually the crypt epithelium developed more normally, resulting in the reappearance of poorly to well developed crypts (Fig. 3B and 3C). Occasionally crypts did not reappear but the epithelial cells were arranged in cyst-like formations. Usually an epithelium lined cyst-like space developed around the mucosal surface of the xenograft (Fig. 3D). The lamina propria and muscularis mucosa remained intact during the entire period. The whole graft was usually surrounded by a thin rim of fibrous tissue, rather cellular initially but more collagenous after 5 weeks. 


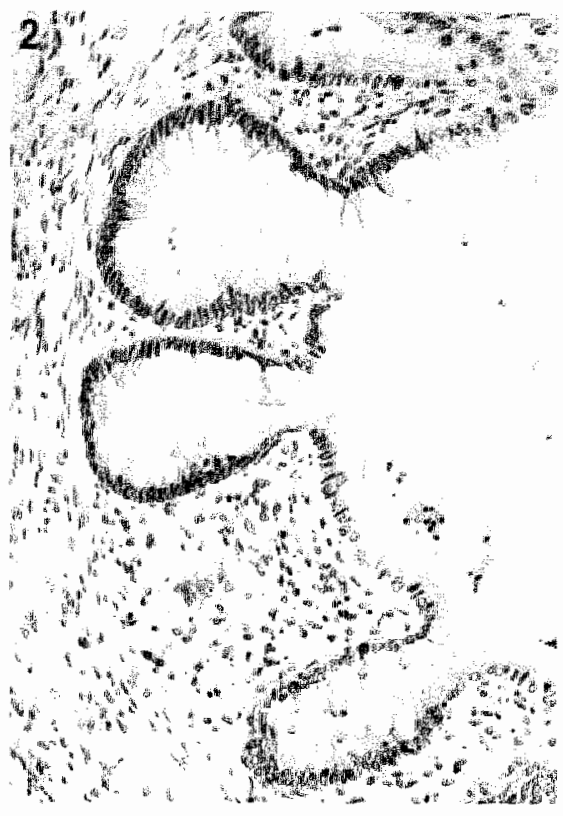

Figure 2. Normal colonic like crypt structure 2 weeks after xenografting normal human colon into a Balb/c mouse $(x 180)$.

The differentiation characteristics of the epithelial structures varied somewhat for the three recipients. Crypts with well differentiated epithelium occurred at 2 weeks in xenografts in Balb/c and NMRI mice but only at 4 weeks in CD-1 mice (Fig. 2, 5 and 3C). At all stages by immunocytochemistry intense immunoreactivity for secretory component was found, even in flat or cuboidal epithelial cells (Fig. 3B). These celis also expressed CEA (Fig. 4). In most xenografts Grimelius positive cells and inmunoreactive serotonin could be detected (Fig. 6). HIDAB staining showed that, comparable to the situation in normal colonic mucosa, sulphomucins were the predominant mucin type in the xenograft (Fig. 5). Sulphomucins were detected in goblet cells, in the cytoplasm of flattened epithelia not morphologically recognizable as goblet cells and in the apical plasma membrane of these cell types. Sialomucins were occasionally seen in cyst lumina.

In all epithelial structures DNA synthesizing cells could be detected by virtue of BrdU incorporation (Fig. 7). Wherever crypts were formed DNA-synthesizing cells were localized in the crypt base. In cyst-like spaces DNA symthesizing cells were rather randomly distributed. 


\section{A}
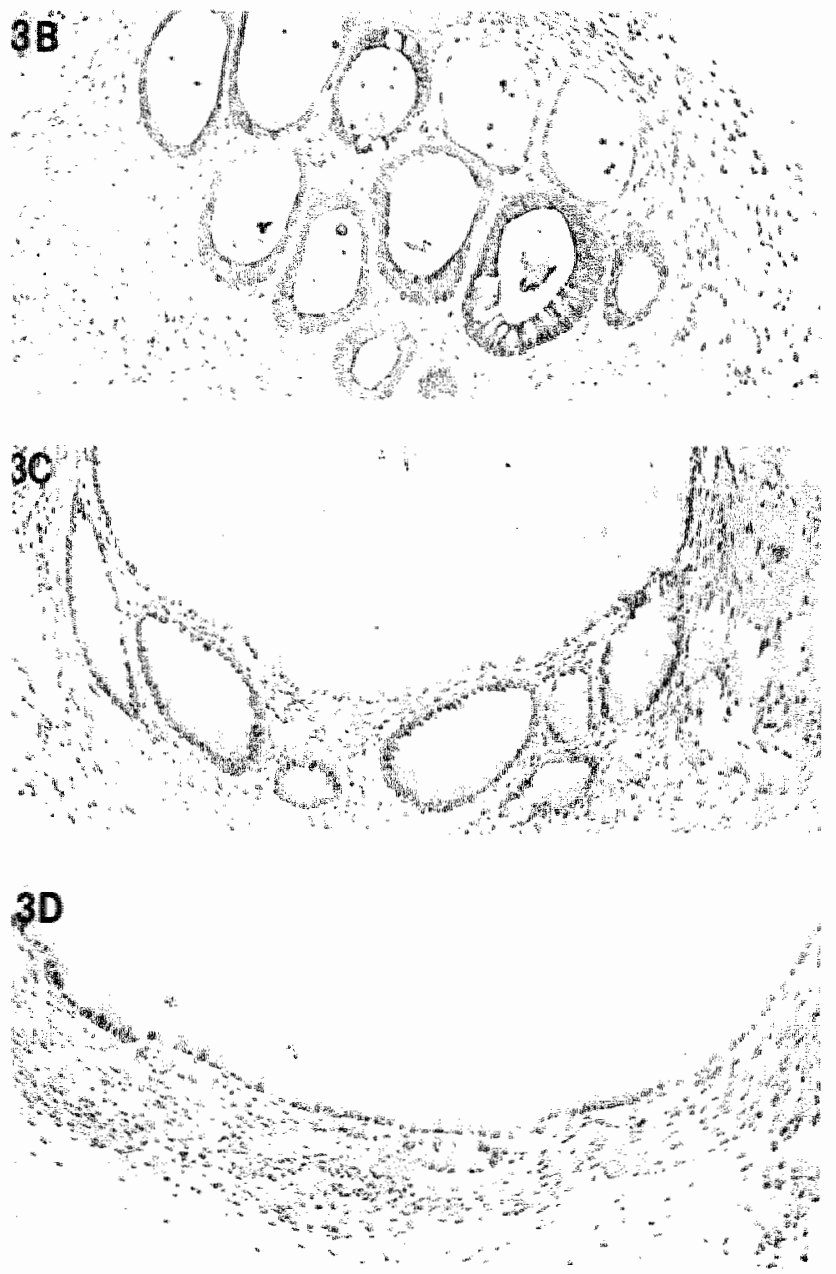

Figure 3. Fate of normal human colon xenograft at various times after implantation $(x 60)$.

A. Xenograft 1 week after implantation. Vital epithetial cells at crypt base. Above vital cells remnants of necrotic epithelial cells are seen.

B. Xenograft 2 weeks after implantation stained with secretory component. Epithelial cells start to repopulate the crypts. Cells show a strong apical $S C$ reactivity.

C. Xenograft 4 weeks after implantation. Showing normal crypt like structures lining a cyst like structure.

D. Xenograft 5 weeks after implantation. A lange cyst like sinucture lined with cuboid to prismatic epithelium. Focal goblet cells are present. One crypt like structure observed. 


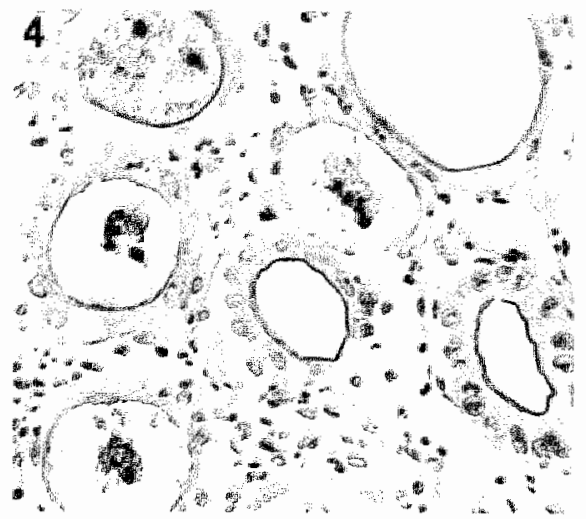

Figure 4. Xenograft 3 weeks after implantation stained for $C E A$ reactivity. Cells show a clear apical brush border reactivity $(x 180)$.
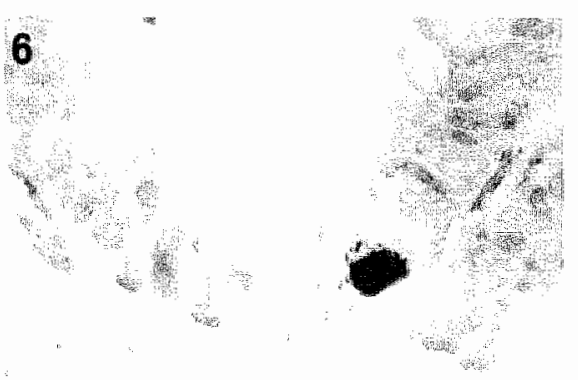

Figure 6. Grimelius staining of a human colon graft. A dark granulated enterochromaffin cell is seen $(x 450)$.

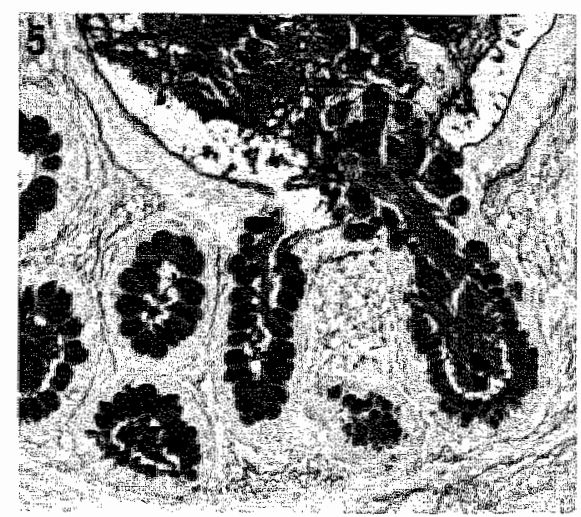

Figure 5. HIDAB staining of 2 weeks old xenograft in NMRI nul nu mouse. Crypts contain mainly sulphomucin producing goblet cells (x180).

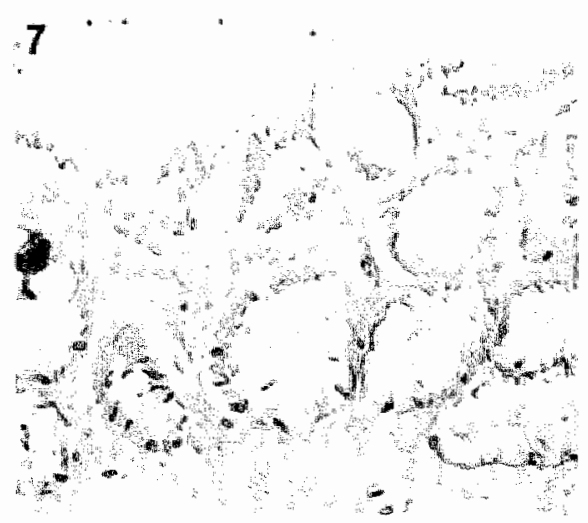

Figure 7. Immunoperoxidase staining of BrdU labeled cells. Immunoreactive (dark stained) nuclei are mainly seen in the lower part of the crypts (x180). 


\subsection{Discussion}

The origin, differentiation and stages of maturation of intestinal mucosal cells have been mainly studied in vivo in the mouse $(2,12)$. For rodent intestinal mucosa the influence of growth factors in vitro (13), and hormones such as insulin, growth hormone in vivo (5) on the process of epithelial cell differentiation has been demonstrated.

Despite the information gathered from these experiments our knowledge about the kinetics, mechanisms of differentiation and interrelation of different stages of maturation in human intestinal epithelium remains limited. This has been largely due to the lack of a suitable model system for the study of human cells in vivo. Since it was established that human tumors can be xenografted in nude mice, attempts have also been made to graft normal human tissues. These efforts have been successful in respect of normal skin (14) human fetal organs (15), breast (7) and endometrium (6). Earlier attempts to xenograft colonic mucosa under the renal capsule of nude mice failed, whereas rodent colonic mucosa survived up to 45 days in the same system (16).

Our experiments show that normal adult human colonic mucosa can be successfully grafted subcutaneously into nude mice and remain vital for a period of at least 5 weeks. A characteristic sequence of events was observed. Initially most crypt cells degenerated and only crypt base cells remained. Gradually, epithelial cells repopulated the crypts and finally mature epithelial cell types could be observed, indicative of normal enterocytic differentiation. The observed cyst formation is probably due to accumulation of debris and secretion products. After about 5 weeks xenografts seemed to degradate. Further studies are needed to show the fate of xenograft after prolonged xenografting.

Our results suggest that epithelial cell proliferation in the xenografts is determined by revascularization of the graft, host response to the graft and stromal factors within the graft. The initial occurrence of epithelial cell degeneration, followed by a time dependent reappearance of epithelial cells suggests that vascularization of the graft is an important determinant in its final fate. This contention is supported by the persistence of stromal elements from the lamina propria and smooth muscle cells from the muscularis mucosae, which are more resistant to anoxic injury. The differences in immunocompetence between the different mouse strains are illustrated by the differences in the incidence of abscess formation, which occurred much more frequently in Balb/c and NMRI than in CD-1 mice. 
This observation parallels the differences in the take rate of inoculated tumor cells between animals with different immunocompetence as reported by Drewinko et al (19). Conceivably, a more intense immunologic reaction of $\mathrm{CD}-1$ mice to the xenograft leads to a delay in the reappearance of mature epithelial cells, which occurred at 2 weeks in Balb/c and NMRI mice but only after 4 weeks in CD-I mice. The importance of stromal factors in growth and differentiation of the grafted epithelia is indicated by the selective outgrowth of epithelial cells in remnants of preexisting crypt structures. The influence of stromal factors on epithelial cell growth and differentiation has been previously demonstrated by Cunha and collaborators in the genitourinary tract (20). Further analysis of the interaction of colonic epithelial and stromal cells can be performed by grafting of isolated epitheliall cells with and without stromal fibroblasts. Procedures for the isolation of colon epithelial crypt cells have been described $(17,18)$. Single cell suspensions of murine fetal colonic epithelium have proven to retain proliferative capacity (13). Grafting of epithelial cell suspensions would also allow the study of the interaction between epithelium and mesenchymal stroma. In this in vivo model the kinetics, differentiation and maturation of normal human large intestinal epithelium can be studied. The interrelation of proliferation and differentiation can be investigated using double labeling immunocytochemical techniques for the demonstration of nuclear BrdU incorporation after pulse or continuous BrdU administration and markers of intestinal cell differentiation (11). Also the influence of growth factors and hormones on the proliferation and differentiation of human colonic mucosa can be studied. 


\section{References}

1. Galjuard $H_{0}$ Bootsma $D$. The regulation of cell proliferation and differentation in ingestinal epilhelium. Exptl. Cell Res. 1969, 58: 79-92.

2. Cheng $H$, Leblond $C P$. Origin, differemigaion and renewal of the four main epitholial cell

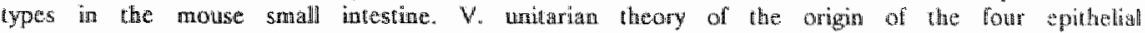
cell types. Am. J. Anat. 1971, 141: $537-562$.

3. Schff Ly. Moore SI. Organ culure of adult rat colonic mucosa on hibrin foam. In Viro 1980, 16: 893.906.

4. Senion PV, Pritchett CJ, Suner JP, Appleton DR. Watson AJ. Cypt regentation in aduli human colonite mucosa during prolonged orgas culture. J. Anta. 1982, 134: 459.469.

5. Cooke PS, Yonemara CU, Russell SM, Nicoll Cs. Growh and differentation of fots rat intestine transplants: dependemce on insugin and growth hormone. Bioł. Neonate 1986, 49: $211-218$.

6. Bergqvist $A_{0}$ Jeppsson $S$, Kullander $S$, Ljungberg $O$. Hunan endonetrium transplanted into nude mice. Histological effects of various steraid hormones. Am. 1. Patliol. 1985, 119: 336. 344.

7. Dubois JD, OHara MJ Gusterson BA. Evidence for lacration in human breast organow xenografts being independent of local mammary factors. J. Pathol. 1986, 146: 98A-99A.

\&. Spicer SS, Henson JG. Methods for localizing mucosubstances in epithelual and conncotive fissue. Methods Arch. Exp. Pathol. 1967, 2.78-112.

9. Grimelius $\mathbb{L}_{\text {. A }}$ A silver nitrate stain for -1 cels in human pancreatic islets. Acha boc. Med. Up: $1968,73: 243.270$.

10. Arends JW, Wiggers T, Thijs CT, Verstijnen $C$, Swaen GJV, Bosman FF. The value of secretory componem (SC) immunoreaciotity in diagnosis and prognosis of colorectal carcinomas. Am. J. Clin. Pathol. 1984, 82: 267274.

11. Sebutte $B_{\mathrm{a}}$ Reynders MMJ, Bosman FT, Blijham G. Studies with andi-bromodenxyuridine antibodies. Simultaneous immunocytochemical detaction of antigen expression and DNA synthesis by in vivo tabeling of mouse intestinal mucosa. J. Histochem. Cylochem. (accepted for publication)

12. Andrew $A$, Kramer $B$, Rawdon BB. The embryonic origin of endocrine eells of the gatitrountestinal traet. General Comp. Endocrinol. 1982, 47; 249-265.

13. Pyke KW, Gogerly RL. Murine fetal colon in vitro: assays for growth factors. Diferentiation $1985,29: 56-62$.

14. Reed ND, Manuing DD. Present status of xemotransplantation of nonmalignant tissuc lo the mude mouse. In: The nuxle Mouse in Experimental and Clinical Research. J. Fogth and BC Giovanella (eds), Academic Press New York 1978, 167\%185.

15. Povlen CO, Shakkeback NE, Rygaard J, Jensen $Q$. Heteronansplantation of huma foctal organs to raose mulant nude. Nature Lond. 197\%, 248: 247-249.

16. Bhargava DK, Lipkin $M$. Transplantation of adenomatons polyps, normat colonic mucona and adenocarcinoma of colon into athymic nuce. Digestion 1981, 21: 225-231

17. Buil DM. Bookman MA. Isolation and functional characterization of finman intestimal muensal lymphoid cells. J, Clin. Invest. 1977, 59: 966-974.

18. Ten Kate $J_{1}$ Verspage $H$, Wünen $J$, Mieremet $M$, wan den Ingh $H$, Bosman Fl, Meera Khan P. Maturation dependant changes in wucleoside phosphorylase (NP) adenosine doaminaste (ADA) and ADA complexing protein (ADCP) in intestinal epithelial cells. In: Proxcedinger of the 32nd Colloquium Protides of the Biological Fluids $H$ Peders (cd). Pergamon Pross Oxford 1985, 339-342.

19. Drewinko $B$, Yang LA, Leibovitz $A$, Barlogie $B$, Lutz $D$, Jansson $B$, Seragand JJ, "Trugillo IM. Cellular discriminants for a biological classifucation of human colon carcinoma. Cancer 1984, 44: $4241-4253$.

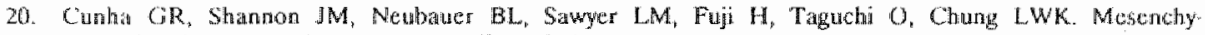
mal-epltheliall interactions in sex diflerentation. Hum. Genet. 1981, 58: 68-77. 


\section{CULTURING AND XENOGRAFTING OF PRIMARY COLORECTAL CARCINOMA CELLS: COMPARISON OF IN VITRO AND IN VIVO MODEL AND PRIMARY TUMOR.}

\subsection{Introduction}

For the study of the biology of human cancer, tissue culture has become an accepted method which has also found wide application in colorectal cancer research. In recent years the establishment of many colorectal carcinoma cell lines has been reported (1). A limitation of the in vitro approach is that only a minority of colorectal carcinomas yields cell lines that can be continuously cultured (2). Recent improvements in the tissue culture methodology, including more efficient methods to obtain single cells from cancer tissue (3), enriched media (4), the use of feeder layers (5) and addition of growth factors (6), have led to a higher successrate. An additional limitation, however, is that cell lines obtained from human cancer may present but a selection of the properties of the primary tumor cells. To limit this problem, the possibility to xenograft fragments of human cancer tissues into immunodeficient mice has been extensively explored (7). It has been shown that tumor xenografts have characteristics which make them useful as a model for the study of human cancer. To be of value for the analysis of the biology of cancer in man, however, in vitro and in vivo model systems should show tumor cell characteristics corresponding with those of the primary tumor cells. Several studies have been published in which various aspects of tumor cell biology in the primary tumor were compared with the in vitro situation and with in vivo xenografts. Freeman and Hoffman 1986 (10) have shown that human colon cancer explants grown on collagen gels retain their in vivo growth characteristics. Other investigators $(8,9,11,12)$ have reported that colonic carcinoma cell lines after inoculation into nude mice yield tumors which histologically resemble the primary tumor. Sharkey et al (13), however, reported that in $25 \%$ of the xenografts differentiation 
was different in comparison with that in the primary tumor. These investigations showed a successrate for xenografting of $72 \%$, which is much higher than for cell culturing.

In the present study we have attempted to obtain cell lines as well as serially transplantable tumors from consecutive primary human colorectal carcinomas. This report summarizes the results with particular emphasis on factors which influenced the successrate and on a comparison of the cellular characteristics of primary, in vitro and xenografted cells.

\subsection{Materials and Methods}

Tissue culture

Colorectal cancer tissue was obtained from colectomy specimens within $30 \mathrm{~min}$ after operative removal of the specimen. Tissue fragments (approximately $1 \mathrm{~cm}^{3}$ ) were washed in HEPES buffered RPMI 1640 medium (Flow Laboratories). Subsequently the tissue fragments were briefly dipped in $70 \%$ ethanol to eliminate superficial bacterial contamination. Further tissue processing was performed in a laminar flow cabinet under sterile conditions. The outer surface of the tissue fragments was carefully dissected. The central part of the tissue was fragmented using scalpel blades, until the fragments could be passed through a Pasteur pipet. Tissue fragments were washed to remove necrotic debris. Subsequently the fragments were suspended in Dulbecco's modification of Eagle medium (DMEM, Flow Laboratories) supplemented with 20\% fetal calf serum (FCS, Sera Lab) to which penicillin (100 $\mathrm{\mu g} / \mathrm{ml})$ and streptomycin (100 $\mu \mathrm{g} / \mathrm{ml}$ ) were added. This material was seeded in $25 \mathrm{~cm}^{2}$ tissue culture flasks (Falcon) and cultured in an atmosphere of $7 \% \mathrm{CO}_{2}$ in air in a humidified incubator. Primary cultures showed growth of epithelial cells as well as fibroblasts. Several methods were used to remove fibroblasts, including selective trypsinization, mechanical removall of fibroblasts or epithelial cells or (in case of anchorage independent growth of epithelial cells) subculturing of supernatant medium.

\section{Xenografting}

Xenografting was performed in NMRI nu/nu or CD-1 nu/nu mice. The animals were housed under sterile conditions in a laminar flow cabinet in an SPF barrier. Tissue fragments, prepared as for tissue culturing and with a maximum size of 1 to $2 \mathrm{~mm}^{3}$, were implanted 
subcutaneously into the flank. In some cases insufficient primary tumor material was available. In these cases xenografting was attempted after establishment of primary cultures in vitro. Xenograft growth was monitored by weekly measurement of xenograft size using a pair of calipers. Serial transplantation was performed by fragmentation of the xenograft tissue as described above and subcutaneous reimplantation.

\section{DNA index}

The DNA index was determined in primary tumors as well as in the xenografts and in the cell cultures. When fresh material was not available nuclei were recovered from paraffin embedded tumor tissue using a technique which was described extensively elsewhere (14). The preparative procedure involved cutting of $50 \mu \mathrm{m}$ sections, deparalfinization, rehydration and tissue digestion using trypsin. Fresh tissue from xenografts was fragmented with scalpel blades, filtered through nylon gauze and lixed in 70\% ethanol. From tissue culture, cells were recovered by trypsinization. In these materials DNA was stained using Propidium Iodide in a technique dlescribed by Vindelov (15). The DNA index was determined by flow cytometry, using a FACS IV cell sorter (Becton \& Dickinson):

\section{Antigen expression}

Morphological as well as histochemical characteristics of differentiation were studied in the primary tumor, cell lines and xenografts. Tissue morphology of the primary tumor and the xenografts were studied in paraffin embedded sections stained with hematoxylin and eosin. Differentiation was furthermore assessed by histochemistry using PAS and HIDAB staining for the assessment of mucin production and an immunocytochemical technique for the assessment of production of serotonin (characteristic of endocrine cells), secretory component (characteristic of columnar cells), lysozyme (characteristic of Paneth cells), and carcinoembryonic antigen (CEA). Antisera against serotonin, secretory component, lysozyme and CEA were commercially obtained (Dakopatts). Details on the applied immunoperoxidase procedure have been previously reported (16). Briefly, routinely processed rehydrated $5 \mu \mathrm{m}$ paraffin sections were subjected to $0.1 \%$ trypsin for 25 min. After blocking of endogenous peroxidase activity and preincubation with $20 \%$ normal swine serum the sections were incubated with the specific rabbit antiserum (RT, $30 \mathrm{~min}$ ). Subsequently the slides were incubated with peroxidase conjugated swine anti rabbit 
antiserum. Peroxidase activity was visualized with $0.01 \% \mathrm{H}_{2} \mathrm{O}_{2}$ and $0.5 \%$ diaminobenzidine in $0.05 \mathrm{M}$ Tris- $\mathrm{HCl}$ buffer $(\mathrm{pH}$ 7.6) and the sections were counterstained with haematoxylin.

\subsection{Results}

In the course of the study 46 primary colorectal carcinomas were investigated. From 13 specimens tumor cells could be propagated in vitro or in vivo, a combined successrate of approximately $30 \%$. Four of these cases $(9 \%)$ concerned cell lines, which could be maintained in continuous culture and $10(22 \%)$ concerned xenografts which could be serially transplanted. One of these cell lines (5583) grew both in vivo and in vitro.

\section{Tissue culture}

A major factor in the unsuccessful attempts of culturing primary colorectal carcinoma cells appeared to be bacterial contamination. In some specimens bacterial contamination prevented tumor cell growth. These specimens were not included in the present analysis of 46 tumors. In a few cases the primary cultures only showed fibroblasts. In most cases, however, after a few days clusters of substratum adherent epithelial cells were observed. Often these cell clusters regressed within a few days. In other cases cell growth continued for periods of time varying between one week up to several months, after which regression occurred. From our series of primary tumors four cell lines from different tumors were obtained that could be continuously propagated in tissue culture. The 5583 cell line is extensively described elsewhere (17). Cell lines 7355 and 7248 show anchorage dependent growth of epithelial cells (Fig. 1 and 2). The 7248 cell line is of particular interest because it displays a malignant phenotype, although it was established from a tubular adenoma. Cell line 4224 consists of anchorage independent spheroid cells and occasional cell clusters (Fig. 3).

\section{Xenografting}

In a about $25 \%$ of cases xenografting was unsuccessful due to bacterial contamination of the grafted specimen, resulting in abscess formation at the site of implantation. In five cases xenografts were established from early passages of cultured primary tumors. This was performed when insufficient primary tumor material was available for xenografting. 


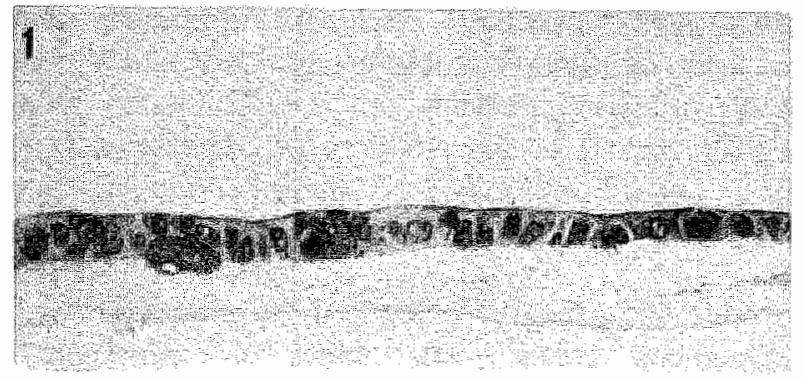

2
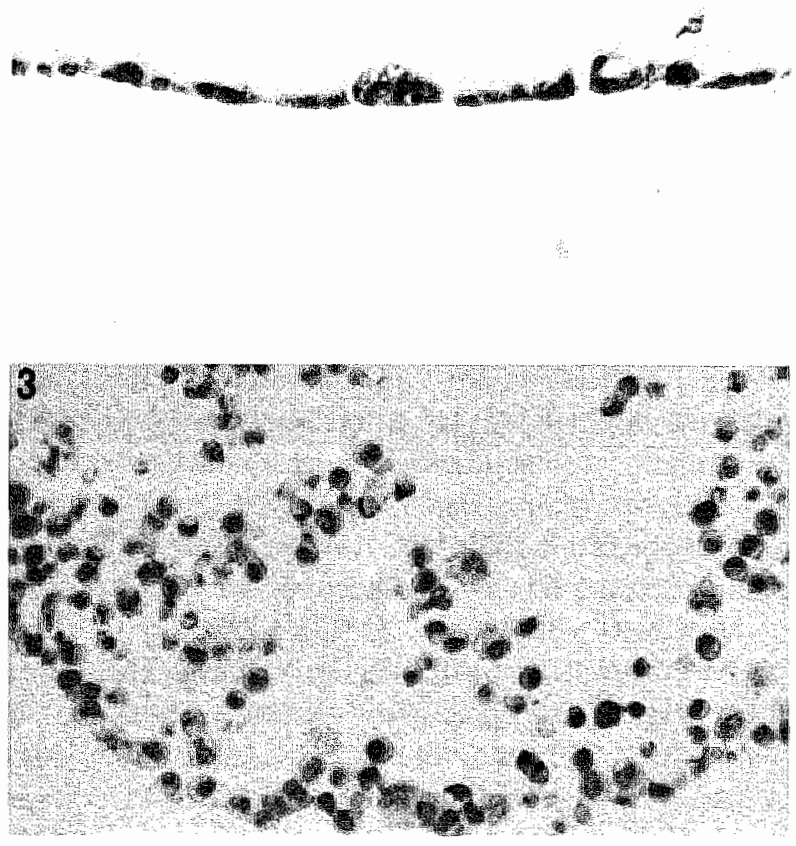

Figure 1. Celline 7355 grown on amniotic membranes ( $H E, x 180)$. The cells form a monolayer of cuboid to prismatic cells.

Figure 2. Celline 7248 grown on amniotic membranes (HE, x180). The cells form a more irregular monolayer in which often goblet-like cells are observed.

Figure 3. Celline 4224 embedded in soft agar (HE, x180). 4224 consists of round cells with a somewhat eccentric nucleus.

Initial implantation of cancer tissue invariably showed a long lag phase without appreciable tumor growth. Subsequent serial transplants usually resulted in much more rapid tumor growth. Attempts to culture xenografts in vitro met with variable success. In some cases (e.g. 5583) cell cultures from xenografted material could be easily 
Table I. Correlation between clinical data and successrate in xenografting and culturing.

\begin{tabular}{lcrr}
\hline $\begin{array}{l}\text { Tumor } \\
\text { characteristic }\end{array}$ & $\begin{array}{c}\text { Successful } \\
\text { attempts }\end{array}$ & $\begin{array}{c}\text { Unsuccessful } \\
\text { attempts }\end{array}$ & Total \\
\hline Sitel & & & \\
prox & $5(39)$ & $6(18)$ & 11 \\
distal & $7(54)$ & $22(67)$ & 29 \\
nd & $1(7)$ & $5(15)$ & 6 \\
\hline
\end{tabular}

\section{Lymphnode}

\section{Metastases}

present

absent

Grade of

differentiation

Wel 1

Moderate

Poor

1
$10(77)$
$2(16)$
1 prox $=$ caecum + colon ascendens
distal $=$ colon descendens + sigmoid + rectum
nd $=$ not determined

(..) percentage

obtained. From other xenografts (e.g. 2246, 2983 and 6913) multiple attempts were made to culture xenografted material. In these cases initial cell growth was observed but epithelial cell proliferation ceased after one week and subsequently the cells regressed.

Correlation with pathological characteristics

In table 1 pathological characteristics of the investigated primary tumors in relation to the attempts for propagation are listed. Attempts tended to be more successful in primary carcinomas that had already formed regional lymphnode metastases $(62 \%)$. In contrast, only $30 \%$ of the unsuccessful attempts concerned primary tumors with regional lymphnode metastases. This difference is not statistically significant $(p=0.10)$. A tendency for a higher successrate was also found in 
Table II. Pathological characteristics of the successfully propagated primary tumors in vitro and in vivo.

\begin{tabular}{|c|c|c|c|c|c|c|c|c|}
\hline & Location & $\begin{array}{l}\text { Metas- } \\
\text { tases }\end{array}$ & $\begin{array}{l}\text { Differen- } \\
\text { tiations }\end{array}$ & $\begin{array}{l}\text { In } \\
\text { vitro }\end{array}$ & $\begin{array}{l}\text { In } \\
\text { vivo }\end{array}$ & $\begin{array}{c}\text { Origin } \\
\text { xenograft }\end{array}$ & $\begin{array}{l}\text { Time } \\
\text { delay }\end{array}$ & $\begin{array}{c}\mathrm{Nr} \text { of } \\
\text { passages }\end{array}$ \\
\hline 2246 & $S$ & + & M & - & + & $P$ & & $10^{*}$ \\
\hline 2983 & $S$ & + & $\mathrm{P}$ & - & + & $C$ & 37 & $21^{*}$ \\
\hline 5583 & C & - & $M$ (nuc) & + & + & $C$ & 78 & $20^{*}$ \\
\hline 7355 & $S$ & + & $M$ & + & - & & & \\
\hline 5710 & A & - & G & - & + & $\rho$ & -- & $4^{*}$ \\
\hline 6362 & $S$ & + & $M$ & - & + & P & -- & $3^{\star}$ \\
\hline 6548 & $u$ & + & $M$ & - & + & C & 30 & $1^{*}$ \\
\hline 6913 & $R$ & - & $M$ & - & 4 & C & 120 & 6 \\
\hline 7248 & $S$ & & adenoma & * & - & & & \\
\hline 8053 & RS & + & M & - & + & c & 127 & $1 *$ \\
\hline 4224 & A & - & $p$ & + & - & & & \\
\hline 7375 & C & + & $\mathbb{M}$ & $n t$ & + & $P$ & - & 4 \\
\hline 8461 & C & + & $M($ muc $)$ & $n t$ & + & P & - & 2 \\
\hline $\begin{array}{l}S= \\
A= \\
C= \\
R= \\
x= \\
x\end{array}$ & $\begin{array}{l}\text { signoid } \\
\text { ascending } \\
\text { caecum } \\
\text { rectum } \\
\text { discontinut } \\
\text { Time dellay } \\
\text { cases wher } \\
\text { cont inuous } \\
5583 \text {. }\end{array}$ & $\begin{array}{l}\text { colon } \\
\text { red for } \\
\text { re peri } \\
\text { cultu }\end{array}$ & \multicolumn{6}{|c|}{$\begin{array}{ll}u=\text { unknown } & N T=\text { not tested } \\
W=\text { well differentiated } & P=\text { primary tumor } \\
M=\text { moderately differentiated } & C=\text { tissue culture } \\
P=\text { poorly differentiated } & \\
\text { technica) reasons } & \\
\text { od (days) in tissue culture before xenografting in } \\
\text { nograft was established from cultured cells. Note: } \\
\text { res of these carcinoma were only obtained from }\end{array}$} \\
\hline
\end{tabular}

tumors in the proximal colon (caecum + colon ascendens) in comparison with those in the rest of the colon (39\% versus 18\%). As most of the tumors showed moderate to well differentiated histology, a correlation between grade of differentiation and successrate could 
Table III. DNA index of primary tumor and xenograft in mude mice.

\begin{tabular}{llcl}
\hline NR. & $\begin{array}{l}\text { Primary tumor } \\
\text { DNA index }\end{array}$ & Pas. nr. & \multicolumn{2}{c}{ Xenograft } \\
& $1,161,54$ & 2 & $1,081,72$ \\
2246 & 1,26 & 4 & $1,281,462,40$ \\
2983 & 1 & 2 & 1 \\
5583 & 1,82 & 4 & 1,81 \\
5710 & 1,65 & 1 & 1,75 \\
6362 & 1,52 & 1 & 1,63 \\
6913 & 1,31 & 5 & 1,41 \\
8053 & 1 & 1 & 1 \\
\hline
\end{tabular}

not be statistically evaluated. However, of the two poorly differentiated carcinomas one could be serially transplanted (2983) and one could be maintained in tissue culture (4224). In contrast, of the three well differentiated carcinomas only one could be propagated as a xenograft (5710). In table 2 the characteristics of the successfully propagated primary tumors are listed. Only one tumor could be continuously kept in vitro as well as in vivo (5583). In all other cases tumors could be either serially transplanted or cultured only. Of the xenografts $5(60 \%)$ were obtained by grafting of early passages of cultured cells.

\section{DNA index}

From 9 tumors material was available for DNA analysis. The results are summarized in table 3. Most tumors contained one stemline which recurred in the xenograft.

One tumor (2246) showed two stem lines, one of which recurred in the xenografts but the other disappeared. In another tumor (2983) 2 additional stem lines developed in the xenografted material.

\section{Histology}

Histological characteristics of the xenografts in comparison with those of the primary tumors are listed in table 4. Primary tumors 
Table IV. Morphology and antigen expression of the primary tumor and the xenograft (cell lines).

\begin{tabular}{|c|c|c|c|c|c|c|c|c|}
\hline & \multicolumn{2}{|c|}{ Morphology } & \multicolumn{6}{|c|}{$\begin{array}{l}\text { Antigen expression in xeno- } \\
\text { grafts compared to the } \\
\text { corresponding primary tumor }\end{array}$} \\
\hline & $\begin{array}{l}\text { primary } \\
\text { tumor }\end{array}$ & $\begin{array}{l}\text { xenograft compa- } \\
\text { red to primary }\end{array}$ & $\begin{array}{l}\text { corres } \\
\text { CEA SO }\end{array}$ & & & to toh & Iys & ser \\
\hline 2246 & $W$ & glands wider & $-\quad-$ & - & - & + & 0 & 0 \\
\hline 2983 & $P$ & more cellular & -0 & - & 0 & - & 0 & 0 \\
\hline 5583 & $M$ (mucinous) & $\begin{array}{l}\text { less mucin } \\
\text { more cellular }\end{array}$ & -0 & - & - & - & + & 0 \\
\hline 7355 & M & & nt $n t$ & $n t$ & nt & nt & nt & $n t$ \\
\hline 5710 & $W$ (mucinous) & $\begin{array}{l}\text { more muc in } \\
\text { (colloid like) }\end{array}$ & $-\quad-$ & + & 0 & + & - & + \\
\hline 6362 & $M$ & similar & -0 & 0 & 0 & + & - & - \\
\hline 6548 & M & similar & 00 & 0 & 0 & 0 & - & 0 \\
\hline 6913 & $M$ & more cellular & $-\quad+$ & + & + & + & - & - \\
\hline 7248 & adenoma & & $0-$ & - & a & 0 & - & - \\
\hline 8053 & M & more cellular & $0+$ & + & 0 & 0 & 0 & 0 \\
\hline 4224 & $\mathrm{p}$ & & +0 & 0 & 0 & 0 & - & 0 \\
\hline 7375 & M & more ce 11 ular & $+\quad+$ & + & 0 & + & - & 0 \\
\hline 8461 & $M$ (muc inous) & similar & nt nt & $n t$ & $n t$ & nt. & $n t$ & $n t$ \\
\hline $\begin{array}{l}W=n \\
M=n \\
P=p \\
-= \\
+=n \\
0=e\end{array}$ & $\left.\begin{array}{l}\text { ell differenti } \\
\text { oderately diff } \\
\text { oorly differen } \\
\text { ess } \\
\text { ore } \\
\text { qual }\end{array}\right\}$ ant & $\begin{array}{l}\text { ated } \\
\text { erentiated } \\
\text { tiated } \\
\text { igen expression }\end{array}$ & & & & & & \\
\hline
\end{tabular}

often showed heterogeneity with regard to degree of differentiation as well as antigen expression. Xenografts predominantly displayed areas with the lowest level of differentiation of the primary tumor 

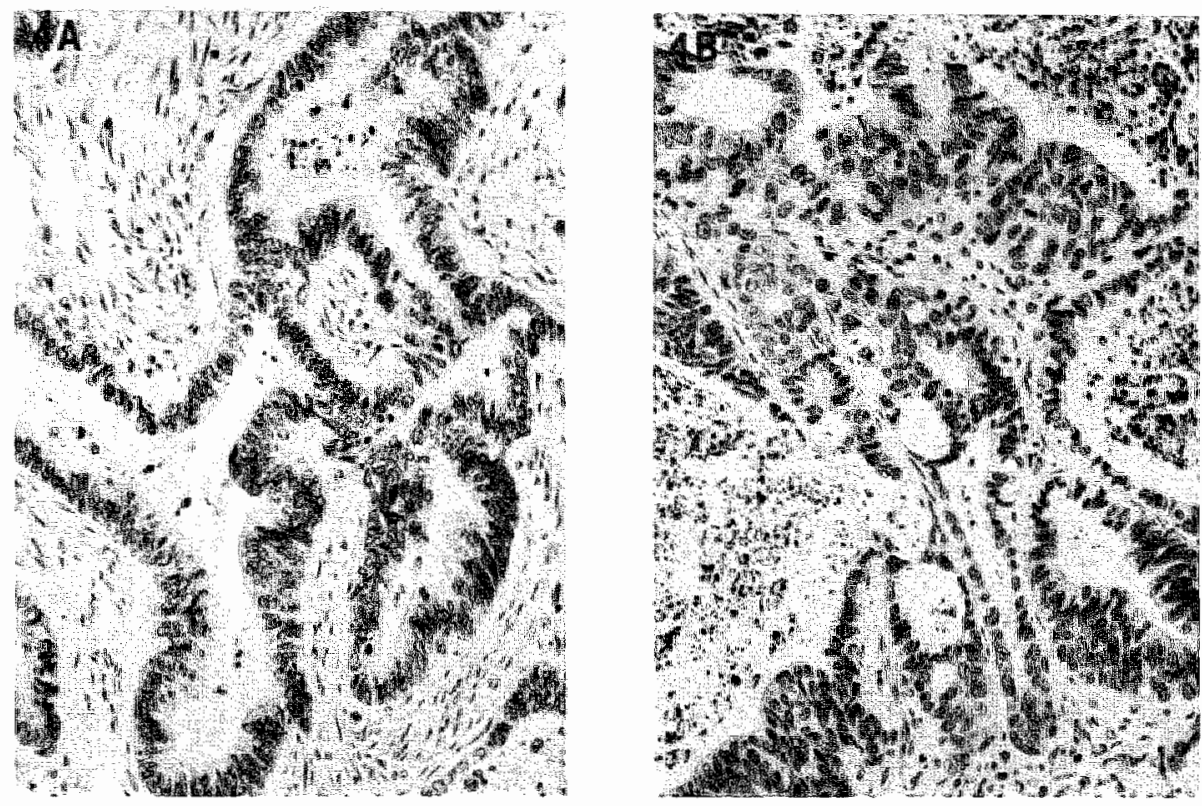

Figure 4. Tumor 6913 (4A) and the xenograft (4B) (HE, $x 150)$.

(fig. 4 and 5) and a lower tendency for antigen expression. In some cases the first passages resembled the primary tumor but later passages showed a decreasing level of differentiation. Usually in xenografts less CEA was produced, although occasionally the reverse was found. A striking characteristic of xenografts was more extensive sulphomucin production than in the corresponding primary tumors.

In two tumors major differences between the xenograft and the primary tumor were noted. From one moderately dysplastic tubular adenoma (7248) the in vitro tissue culture showed unequivocal characteristics of malignancy. One well differentiated carcinoma (5710) initially showed xenografts with histological characteristics of a colloid carcinoma. Later passages showed more resemblance to the primary tumor, although mucin production remained a characteristic feature of the xenografts (fig. 6). 

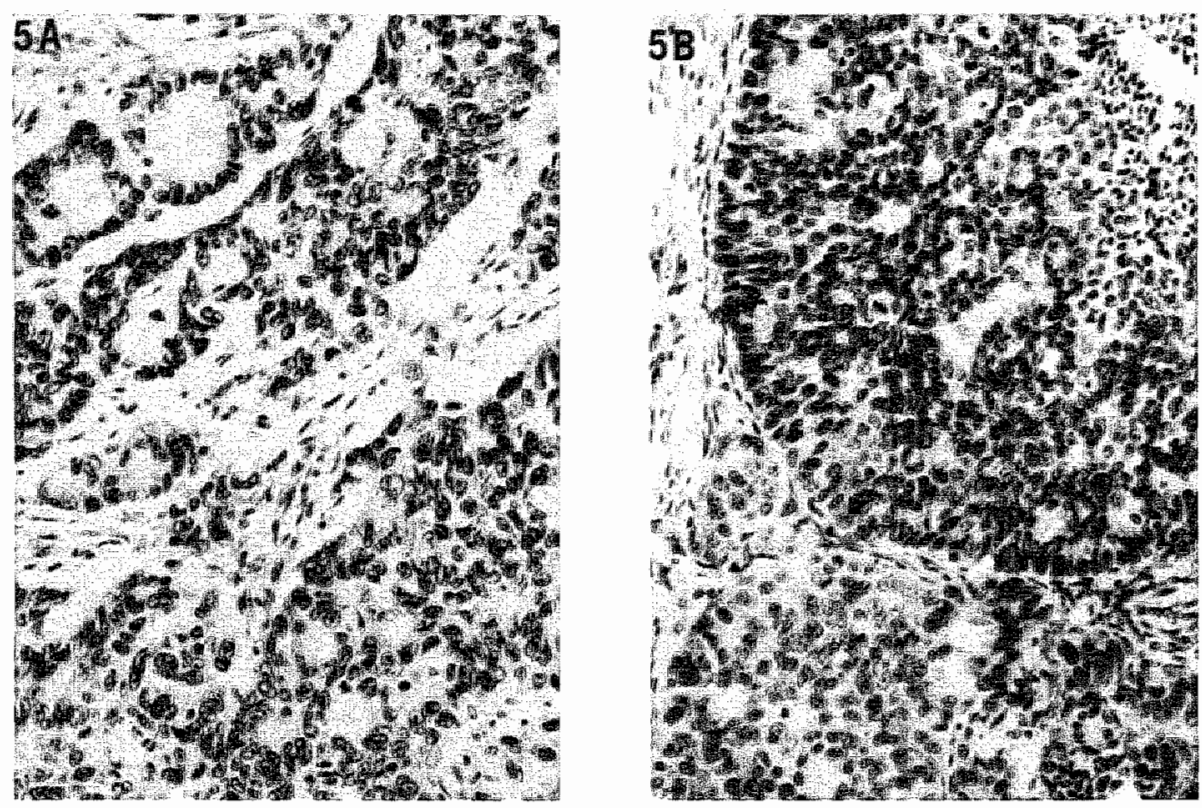

Figure 5. Tumor 2983 (5A) and the xenograft (5B). In the primary tumors adenostructures are present while the xenograft consists of more solid tumors (HE, x150).

Figure 6. Tumor 5710 (GA) and xenograft of passage $I$ (6B) and passage $3(6 B$ and $6 C)(H E, x 150)$.

A. Primary tumor is a well differentiated colon tumor in which goblet cells are seen.

B. The first passage in a nude mouse shows characteristics of a colloid carcinoma.

C. The third passage in the nude mice which is comparable to the primary tumor:

D. Also areas with colloid like structures are present which are also seen in the primary tumor. 

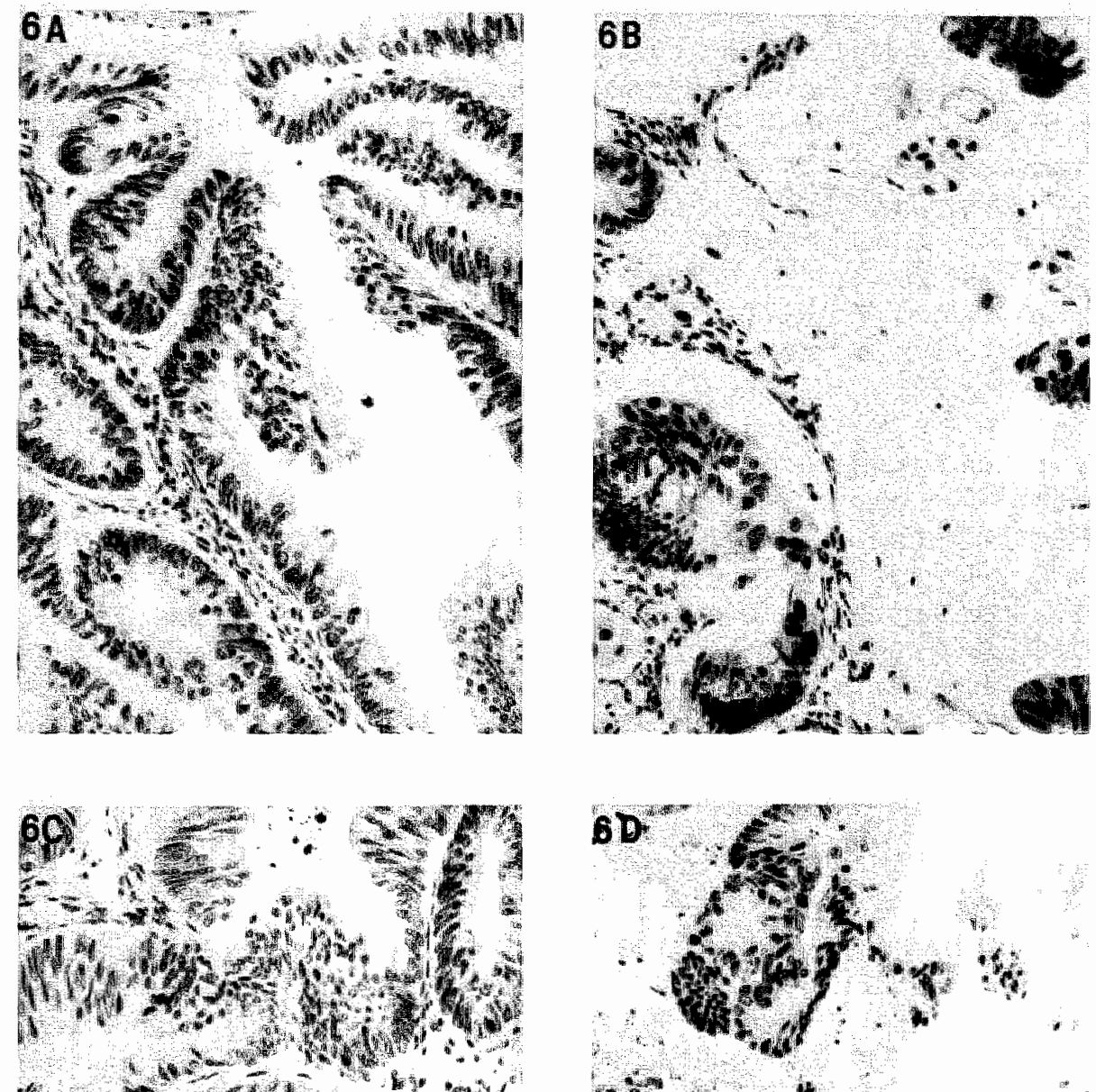

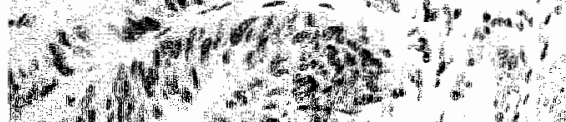

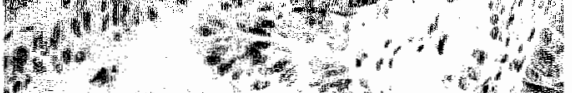

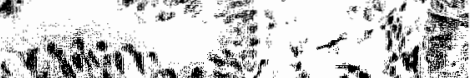

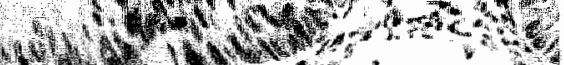

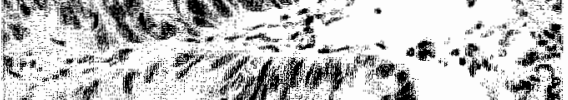

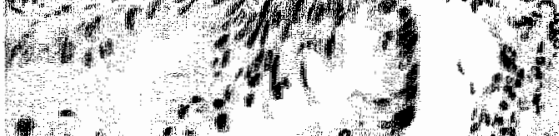

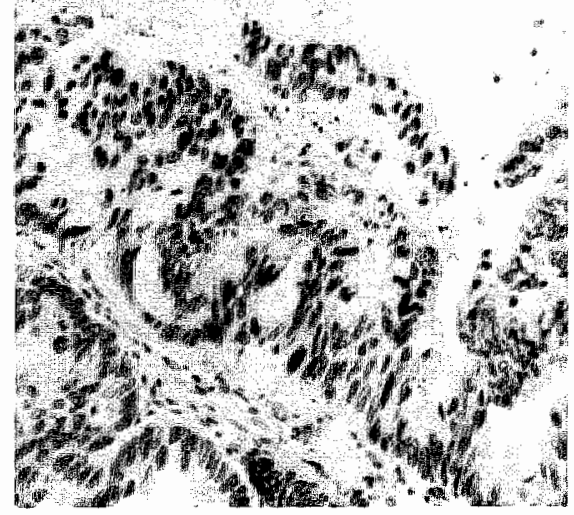




\subsection{Discussion}

Many reports have been published concerning the establishment of buman colorectal cancer cell lines. Most of these described the characteristics of individual cell lines $(9,11,12,18,19)$. Attempts to establish colorectal cancer cell lines from larger series of primary cancers have proven rellatively unsuccessful, partly because of bacterial contamination of the tumor specimens, partly because of fibroblast overgrowth, partly because of apparently limited growth potential of the cancer cells under the chosen conditions. Improvement of tissue culture conditions in combination with the use of antibiotics resulted in a successrate of approximately $10 \%$ in a series described by Leibovitz et al. (2) This is comparable to what we have found. A somewhat higher successrate (30\%) was obtained in a more recent series of 18 primary cancers (20). Using fibroblast feeder layers successrates of up to $80 \%$ have been reported by Brattain et al. (5). These investigators used $\mathrm{C}_{3} \quad \mathrm{H}_{10}$ T1/2 cells which are transformed and might provide growth factors which presumably preferentially stimulate the growth of cancer cells.

Attempts to obtain serially transplantable tumors in immunodeficient animals have been reported by Sharkey (13) and Pratesi (21) who established a successrate of $72 \%$ and $44 \%$ in series of 18 and 9 primary colorectal carcinomas, respectively. Our successrate has been somewhat lower (30\%), conceivably due to the fairly frequent occurrence of abscesses at the site of implantation. In establishing cell lines as well as serially transplantable tumors .of colorectal carcinoma the use of tissues from metastases has appeared to be advantageous because in this material bacterial contamination is not a major problem (20). The finding that most cell lines could only be grown in vitro or xenografted but not both is of some interest. Apparently the capacity for in vitro growth is not intimately related to the capacity to survive as xenograft. We therefore do not consider the capacity of a cell line to form a tumor when xenografted as a reliable indicator for grading of the malignant potential, as has been advocated by Drewinko et al. (23) and Brattain (24).

Some controversy exists in the literature concerning the correlation between metastatic potential of primary carcinomas and their ability to grow in vitro. Kirkland et al (8) found preferential growth of non metastasized carcinomas whereas McBain et al (20) showed a higher successrate for metastasized tumors. We found a trend towards a higher successrate for primary colorectal carcinomas that had already metastasized. This finding is in agreement with those of Fidler et al (22) who demonstrated that in nude mice cancer cells 
from metastases have a selective growth advantage over cancer cells from primary xenografts. We also found a trend for primary carcinomas in the proximal colon to result in a higher successrate than those in the distal colon. There is no apparent explanation for this finding. Conceivably, carcinomas in the proximal colon are detected at a later stage, might have progressed further and henceforth the cells might show a more aggressive behaviour. What exactly determines the ability of a tumor cell to grow in vitio or as a xenograft remains unclear, which is illustrated by the possibility to establish a cell line from an adenoma (celline 7248) (9).

An important element in the present study was the comparison of the characteristics of in vitro and in vivo cell lines with those of the primary carcinoma. For cultured cells a comparison wonld be somewhat artificial due to the totally different growth conditions. Therefore, the comparison was mainly focussed on the xenografts. The primary tumors frequently showed morphological heterogeneity with various grades of differentiation included within one tumor. However, in the xenografts this heterogeneity was less apparent: lrequently the lower grades of differentiation dominated in the xenografts. In some xenografts initially heterogeneity occurred but disappeared in later passages. In terms of antigen expression usually some differences were noticed between primary tumors and their xenografts. However, differences were not always reductions in the extent of antigen expression. Moreover, the differences were often only slight, except for sulphomucin production which was increased in xenografts. The similarity between primary tumor and xenograft is also illustrated by the DNA indices. In only two cases differences were found. One involved a primary with two stemlines of which only one persisted in the xenografts. The other concerned generation of new stemlines in the xenograft.

As mentioned previously, morphological characteristics of cell lines were not systematically compared to those of the primary tumors. In terms of antigen expression, however, similar patterns were found in primaries and their corresponding cell lines. The finding that xenografting of a cell line almost invariably resulted in a tumor that morphologically resembled the original primary tumor supports our impression that in cell lines in vitro the characteristics of the primary tumor are maintained. Similar observations were made by many others $(2,8,9,11,12)$.In conclusion we have shown that of 46 primary colorectal carcinomas in approximately $30 \%$ tumor cells could be propagated in vitro and/or as xenograft in 
vivo. The successrate might be related to the stage or extension of the tumor and for xenografts far exceeds that for cell culture. Usually genotypically and phenotypically the in vitro and in vivo models are quite similar to the primary tumor although xenografts tend to be slightly less heterogeneous and less differentiated. 


\section{References}

1. Rutzky LP. The biology of haman colon fumor cells in culture. Adv Cell Culc. 1985, 4: 47-83.

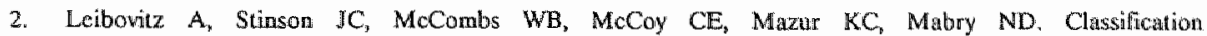
of human colorectal adenocarcinoma cell lines. Cancer Res. 1976, 36: 4562-4569.

3. Moyer MP. A rapid reproducible method for processing human solid fumors for in vitro culture. J. Tissue Cult. Meth. 1983, 8:63-67.

4. Lambert KJ, Birch JR. Cell growth media. Animal Cell Biotechnol. I. 1985, 85-122.

5. Brattain $M G$, Brattain $D E$, Sarrif $A M$, McRae $L$, Fine WD, Hawkins JO Enhancement of growth of buman colon tumor cell lines by feeder layers of murine fibroblasts. JNCI. 1982, 69: 767-771.

6. Gospodarowicz D, Moran JS, Growth factors in mammalia cell calture. Ann. Rev, Biochem. 1976, 45: $531-558$.

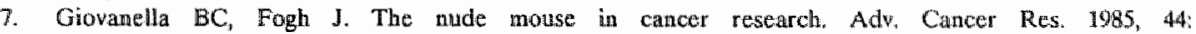
$69-120$.

8. Kirkland SC, Bailey IG. Establishment and characterization of six human colorectal adenocarcinoma cell lines. Br, J. Cancer 1986, 53: 779-785.

9. Paraskeve $C_{n}$ Buckle BG, Sheer $D_{n}$ Wigley CB. The isolation and characterization of colorectal epithelial cell lines at different stages in malignant transformation from familial polyjossis coli patients. Int. J. Cancer 1984, 34: 49.56.

10. Freedman AE, Hoffman RM. In vivo like growth of human tumors in vitro. Proc. Natl. Acad. Sci. USA 1986, 83: 2694-2698.

11. Namba $M_{n}$ Miyamoto $\mathbb{K}_{\text {, }}$ Hyodoh $F$, Iwama $T$, Utsunomiya $J$, Fukushima $F$, Kimoto $T$. Establishment and characterization of a human colon carcinomacell line (KMS-4) from a pattient with hereditary adenomatosis of the colon and rectum. Hnt. J. Cancer 1983, 32: 697-702.

12. Spremulli EN, Scolt $C_{n}$ Campbel] DE, Libbey NP, Shochat D, Gold DV, Dexter DL. Characterization of two metastatic subpopulations originating from a single humbar colon carcinoma. Cancer Res. 1983, 43; 3828-3835.

13. Sharkey FE, Fogh JM, Hajdu SI, Fritzgerald PJ, Fogh J. Experience in surgical pathology with human tumor growth in the nude mice. In: The nude mice in experimental and clinical research. Fogh J, Giovanella BC (Eds.) Academic Press New York, 1978: 187-214.

14. Schutte B, Reynders MMJ, Bosman FT, Blijham GH. Flow cytometric determination of DNA ploidy level in nuclei isolated from paraffin-embedded tissue. Cytometry 1985, 5: 26-30.

15. Vindelov LC, Christensen $I J$ Keiding $N$, Spang-Thomsen $M$, Nissen $N J$. Long-term storage of samples for now cytometric DNA analysis. Cytometry 1983, 3; $317-322$.

16. Arends JW, Verstijmen C, Bosman FT, Hilgers J, Steplewski Z, Distribution of monoclonal antibody-defined monosialoganglioside in normal and cancerous human tissuer: an immunoper. oxidase study. Hybridoma 1983, 2: 219-229.

17. Verstijnen CFHJ, Arends $\mathbb{N}$, Moerkerk PTM, Geraedts JPM, Sckikswa K, Uitendew MP, Bosman FT. The establishment and characterization of two new cell lines derived from a single human colonic adenocarcinoma. Virch. Arch. B. 1987, in press.

18. Rutzky LP, Kaye $\mathrm{Cl}$, Siciliano MJ, Chao M, Kallan BD. Longitudinal karyotype and gentetic signature anallysis of cullured human colon adenocarcinoma cell lines LS180 and LS174T. Cancer Res. 1980, 40: 1443-1448.

19. Dexter DL, Spremulli EN, Fligiel Z, Barbosa JA, Vogel R, Vin Voorhees A, P. Calabresi. Heterogeneity of cancer cells from a single hunam colon carcinoma. Am. J. Med. 198\%, 71: 949.956 .

20. McBain JA, Weese JL, Meisner LF, Wolberg WH, Willson KV. Establishment and chariacterization of human colorectal cancer cell lines. Cancer Res. 1984, 44: $5813-5821$.

21. Pratesi $G$, Pezzoni $G$, Giardini $R$, Doci $R$, Valente $M$, Parmiani $G$. Growt cluaracteristics of thuman colorectal and non-small cell lung tumons xenografted into anude mice: possible correlation with prognosis. "Tumori $1986,72: 351-356$.

22. Fixller 13. Rationale and methods for the use of nude mice to study the bialogy and therapy of human cancer metastasis. Cancer Metast. Rev, 1986, 5: 29-49

23. Drewinko B, Yang LY, Leibowitz A, Barlogie B, Lutz D, Jansson $B_{*}$ Stragand Jj, Trujillo. Cellular discriminants for a biological classification of human colon carcinoma. Cancer Res. 1984, 44: 4241-4253.

24. Bratuain MG, Levine AE, Chakrabarty S, Yeoman LC, Willson JKV, Long B. Heterogeneity of human colon carcinama. Cancer Metast. Rew. 1984, 3: 177-191. 


\section{THE ESTABLISHMENT AND CHARACTERIZATION OF TWO NEW CELL LINES DERIVED FROM A SINGLE HUMAN COLONIC ADENOCARCINOMA.}

\subsection{Introduction}

Though large bowel carcinomas are morphologically fairly uniform, their clinical course and response to therapy is remarkably diverse and unpredictable. Recently, evidence has accumulated that colorectal carcinomas may consist of several subpopulations of cells with differences in such characteristics as DNA-index, karyotype, antigen expression, metastatic ability and response to therapy (1-4). This may be related to the heterogeneous clinical course of large bowel cancers and current research on the biology of these tumors partly focusses on intra- and intertumorheterogeneity. In these studies cell lines derived from colonic cancer cells grown in vitro and xenografted into immune deficient recipients play a pivotal role. Many colonic carcinoma cell lines have been described, the majority growing in monolayers of cells (1-10).

Colonic carcinoma cell lines composed of goblet cells and characterized by abundant production of mucins, have been reported (11). The present study describes such a cell line which was obtained from a mucinous colonic adenocarcinoma. An additional cell line obtained from the same tumor showed differences in its in vitro and in vivo growth, in nude mice, as well as in its karyotype and its expression of differentiation markers.

\subsection{Materials and methods}

\section{Cell culture}

Tissue was obtained from a surgically resected, moderately differentiated mucinous adenocarcinoma of the caecum (Dukes stage B), occurring in a 79 year old female. Fragments of the tumor were cut into small pieces with a pair of scalpels. The small cell clumps 
and single cells thus obtained were washed twice in culture medium to eliminate necrotic debris. The cells were cultured in DMEM (Dulbecco's modification of Eagles Medium, Gibco Europe), supplemented with 10\% heat-inactivated FCS (Fetal Call Serum, Sera-lab.). Penicillin and streptomycin were added during the first week of culture to prevent bacterial growth.

After 1 month of culture two types of cells were observed:

1. Non-adhering cell clusters, exhibiting anchorage-independent growth in the culture medium (designated 5583-S). These cells were propagated by harvesting of the medium and resuspending the cell pellet in fresh medium.

2. Cells exhibiting anchorage-dependent growth as epithelial cell layers (designated $5583-\mathrm{E}$ ). These cells were propagated after detachment by a $0.25 \%$ trypsin-EDTA solution.

For botls cell types, the culture medium was changed once a week or, when cells grew more densely, every two days. For immunocytochemical studies 5583-E cells were grown on the basal lamina of stripped human placental amniotic membranes, prepared according to the method of Liotta et al. (12). Briefly, fresh amniotic membranes were washed with deoxycholic acid and ethylene diamine tetraacetic acid (EDTA) and the amniotic epithelium was removed by scraping with a rubber policeman between and after washings. The membranes were stretched belween stainless steel rings and placed in tissue culture dishes with DMEM- 10\% FCS.

\section{Cell kinetics}

The growth characteristics of 5583-S and -E cells were analyzed using the bromodeoxyiuridine (BrdU) incorporation method as described previously (13). The cell cultures were incubated for varying periods depending on the experiment, in medium containing $10 \mu \mathrm{M}$ BrdU (SERVA).

Nuclear suspensions were prepared and stained by an indirect immunofluorescence technique and a monoclonal anti-BrdU antibody as described previously (Schutte et al., 1987). Stained nuclei were analyzed by flow cytometry on a FACS IV (Beckton \& Dickinson, Sunnyvale, CA) equipped with a $4 \mathrm{~W}$ argon-ion laser. The duration of the S-phase (Ts) was calculated from the movement of BrdU labeled cells through the S-phase after pulse labeling as described by Begg el al. (14). The labeling index (LI) was assessed by determining the fraction of labeled cells after pulse labeling. The growth fraction (GF) was estimated by determining the fraction of labeled cells after continuous 
labeling for $48 \mathrm{~h}$. The potential doubling time (Tpot) was calculated as: $T$ pot $=\frac{T S}{L I}$; the cell cycle time $(\mathrm{Tc})$ was calculated as $\mathrm{Tc}=\mathrm{T}$ pot.GF.

\section{Chromosome analysis}

Karyotyping of exponentially growing cells was performed after metaphase arrest by the addition of $0,3 \mu \mathrm{g} / \mathrm{ml}$ of colcemid to the culture medium, during 1 h. 5583-E cells were harvested by trypsinization. 5583-S cells were also treated with trypsin to dissociate large cell aggregates. After harvesting, the cells were exposed to $0.075 \mathrm{M} K \mathrm{Cl}$ and fixed in three changes of methanol : glacial acetic acid (3:1 V/V). Chromosomes were stained by a Giemsa-trypsin-G-banding procedure.

\section{Growth in semisolid medium}

Plating efficiency in semi-solid medium (soft agar) was determined according to the method of Hamburger and Salmon (1977). Briefly, single cells were suspended in 0,3\% agar (Gibco) in CMRL 1066 medium $+2 \%$ horse serum + additions. A $3 \mathrm{ml}$ sample of this cell suspension was carefully layered on top of $1 \mathrm{ml} 0.5 \%$ agar in McCoy's $5 \mathrm{~A}$ medium $+3 \%$ horse serum $+6 \%$ FCS in a $35 \mathrm{~mm}$ culture dish. Colonies larger than $60 \mu \mathrm{m}$ were counted with an inverse microscope in triplicate dishes 2 weeks after plating. Cloning efficiency was calculated as the percentage of colonies formed relative to the total number of cells seeded per dish.

\section{Tumor xenografts in nude mice}

Xenografting of cultured cells was performed by subcutaneous injection in NMRI nu/nu mice. The subcutaneous injections consisted of $50 \mu \mathrm{L}$ of packed 5583-S or of $10^{7}$ 5583-E cells in $200 \mu \mathrm{l}$ PBS. When a tumor transplant reached a diameter of $1 \mathrm{~cm}$ the animal was sacrificed. The tumor was excised, fixed in $10 \%$ formalin and embedded in paraplast.

\section{Cytochemical procedures}

The expression of differentiation markers was studied by cytochemical and immunocytochemical methods. 5583-S cells were harvested, washed in phosphate buffered saline (PBS), fixed in $10 \%$ buffered formalin, suspended in $2 \%$ agar and the agar blocks were embedded in paraplast. For 5583-E cells, amniotic membranes supporting cell 
colonies of sufficient size were fixed in $10 \%$ formalin and embedded in paraplast or processed for electronmicroscopy.

Mucin production was detected by periodic-acid Schiff (PAS) and high-iron-diamine alcian blue (HID-AB) staining, which allowed the distinction between sialo-and sulphomucins. The presence of secretiory component (SC), (a marker of columnar-like cells), of lyzozyme (a marker of Paneth-like cells), and of carcinoembryonic antigen (CEA) was demonstrated by immunoperoxidase staining as described previously (16). Briefly, $5 \mu \mathrm{m}$ paraplast sections were dewaxed, treated with $0,5 \% \mathrm{H}_{2} \mathrm{O}_{2}$ in methanol to block endogenous peroxidase and trypsinized in a $0.05 \%$ trypsin solution in $0.1 \% \mathrm{CaCl}_{2}$ at $37^{\circ} \mathrm{C}$ for $15 \mathrm{~min}$. To demonstrate $\mathrm{SC}$ and lysozyme, slides were first incubated with rabbit anti-SC and anti-lysozyme (Dakopatts, Copenhagen) and subsequently with sheep anti-rabbit antiserum and rabbit peroxidase-anti peroxidase complex (Dakopatts). Carcinoembryonic antigen was demonstrated with a CEA specilic monoclonal antibody (Parlam 4) (17) using peroxidase labeled rabbit anti-mouse IgG (Dakopatts) as conjugate. Peroxidase activity was visualized with diaminobenzidine and the sections were counterstained with hematoxylin. To determine method specificity, the primary antiserum was omitted as a negative control and tissue known to contain SC, CEA and lysozyme were used as positive reference standards.

\section{Electron microscopy}

For electron microscopy cultured cells were fixed in $2.5 \%$ glutaraldehyde in 0,1 $\mathrm{M}$ phosphate buffer ( $\mathrm{pH} \mathrm{7.2)}$ for $2 \mathrm{~h}$ and in $\mathrm{OsO}_{4}$ for $1 \mathrm{~h}$. Ultrathin sections were stained with uranyl acetate and lead citrate.

\subsection{Results}

\section{Primary culture}

The primary culture contained fibroblasts, epithelial cells growing in suspension and epithelial cells growing in monolayers. Cells in suspension could be selectively propagated from the supernatant medium. Fibroblasts could be separated from the epithelial cells by repeated selective trypsinization, fibroblasts being released before epithelial cells. Separation of the cells growing in suspension from the adherent cells, resulted in the establishment of two cell-lines which have shown stable characteristics for over two years. These 


\section{$1 \mathrm{~A}$}

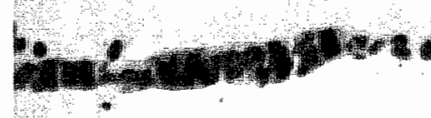

1B
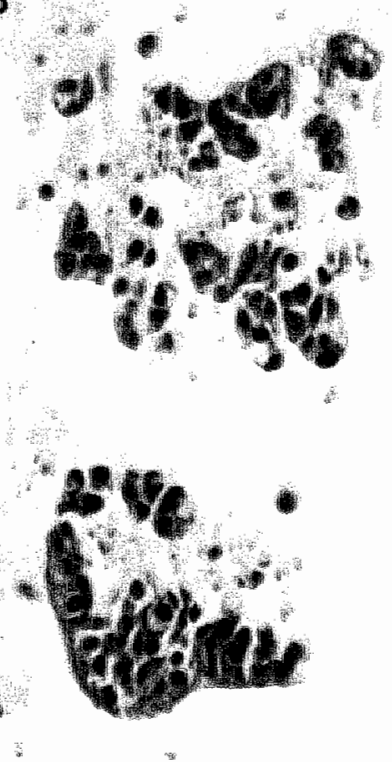

Figure LA. 5583-E cells growing as an epithelial monolayer on placental amniotic membrane (HE, x200).
Figure 1B. 5583-S cells embedded in agar (HE, x200).

cell-lines were studied for following characteristics: growth pattern, growth rate, growth in semi-solid medium, karyotype, morphology of the xenograft in nude mice and the expression of differentiation markers.

Growth pattem

Figs. $1 \mathrm{~A}$ and $1 \mathrm{~B}$ illustrate the growth patterns of $5583-\mathrm{E}$ and $5583-\mathrm{S}$ cells. 5583-S cells showed anchorage-independent growth in clumps 
and multicellular spheroids filled with and surrounded by mucin. The 5583-S cells did not attach to tissue culture plastic or to amniotic membranes after 1 week of culture, while 5583-E cells anchored within 1 day after trypsinization.

When 5583-E cells were kept for prolonged periods at confluence they tended to pile up and detach from the plastic. When detached cells were transferred to new culture vials at lower density they reattached to the plastic indicating a tendency for stable anchorage-dependent growth.

\section{Cell kinetic parameters}

Tabel 1 lists the cell kinetic parameters of 5583-S and 5583-E cells. It is clear that the duration of the various phases of the cell cycle did not differ. The growth fraction of 5583-E cells, however, was somewhat higher, resulting in a shorter potential doubling time.

Table I. Cell kinetic parameters.

\begin{tabular}{lcc}
\hline & $5583-5$ & $5583-\mathrm{E}$ \\
\hline LI & $16 \%$ & $20 \%$ \\
growth fraction & $69.1 \%$ & $75.9 \%$ \\
Ts & $8.9 \mathrm{~h}$ & $9.5 \mathrm{~h}$ \\
Tc & $37.8 \mathrm{~h}$ & $36.1 \mathrm{~h}$ \\
Tpot & $55.6 \mathrm{~h}$ & $47.5 \mathrm{~h}$ \\
\hline
\end{tabular}

Data represent the mean of two experiments

\section{Growth in semisolid medium}

When suspended in soft agar, 5583-S cells did not form colonies and therefore their plating efficiency could not be determined. $5583-E$ cells did grow in soft agar but with a low plating efficiency of between $0.01 \%$ and $0.05 \%$. 
Chromosome analysis

Table 2 lists the karyotypes of both cell lines. Fig. 2 illustrated these karyotypes. All 5583-S cells had a karyotype of $49 \mathrm{XX},+14$, $+12+$ mar 1. 5583-E celis showed variable karyotypes, including a small subpopulation of cells with a karyotype identical to that of 5583-S cells. Both cell lines contained a marker chromosome, an extra chromosome 12 and an extra chromosome 14. The most consistent difference between the two cell lines was the isochromosome 1q, which was only present in 5583-E cells.

Table II. Karyotype of 5583-E and 5583-S cells.

\begin{tabular}{|c|c|c|c|}
\hline cell type & no of cells & & karyotype \\
\hline $5583-S$ & 19 & & $+12,+14 ，+M 1$ \\
\hline $5583-E$ & $\begin{array}{r}8 \\
19 \\
10 \\
6\end{array}$ & $\begin{array}{l}15019 \\
15019 \\
15019\end{array}$ & $\begin{array}{l}+12,+14,+M 1 \\
+12,+14,+M 1 \\
+12,+14,+M 1,+8 \\
+12,+14,+M 1,+2\end{array}$ \\
\hline
\end{tabular}

\section{Xenografts in nude mice}

Cells injected in the flanks of nude mice resulted in tumors with marked morphological differences (Fig. 3A and B). 5583-S cells formed moderately to well differentiated adenocarcinomas containing many large lumina filled with mucin. 5583-E cells formed solid masses with only a few tubular structures in which almost no mucin was detectable. "The morphology of the 5583-S induced tumor was similar to that of the primary carcinoma (Fig. 3C)

\section{Expression of markers of differentiation}

Table 3 summarizes the pattern of expression of differentiational markers in the primary tumor, in 5583-S and $5583-\mathbb{E}$ cell lines and in their xenografts in nude mice.

For three of the markers the primary tumor cells, the cell lines and their xenografts showed comparable patterns of expression. SC reactivity was uniformly present in the primary tumor, both cell lines and their xenografts. However, marked differences were seen in the expression of CEA which was absent in 5583-E cells in vitro as well as in xenografts. The primary tumor showed extensive 


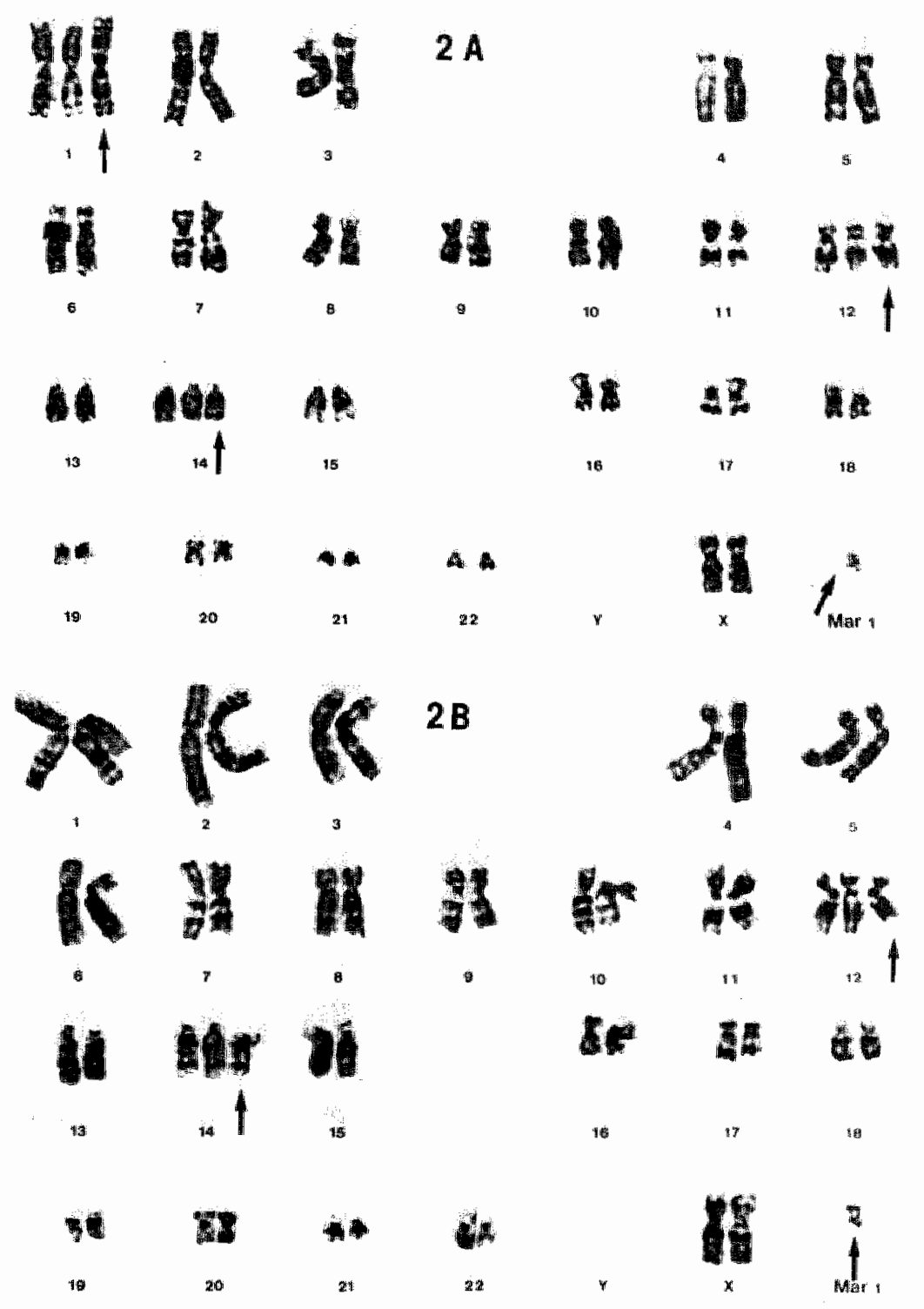

Figure 2. A. Karyotype of 5583-E cell, showing the mar 1 chromosome, isochromosome lq, trisomy 12 and trisony 14 (arrows).

B. Karyotype of 5583-S cell, showing the mar 1 chromosome and trisomy 12 and 14 (arrows). 

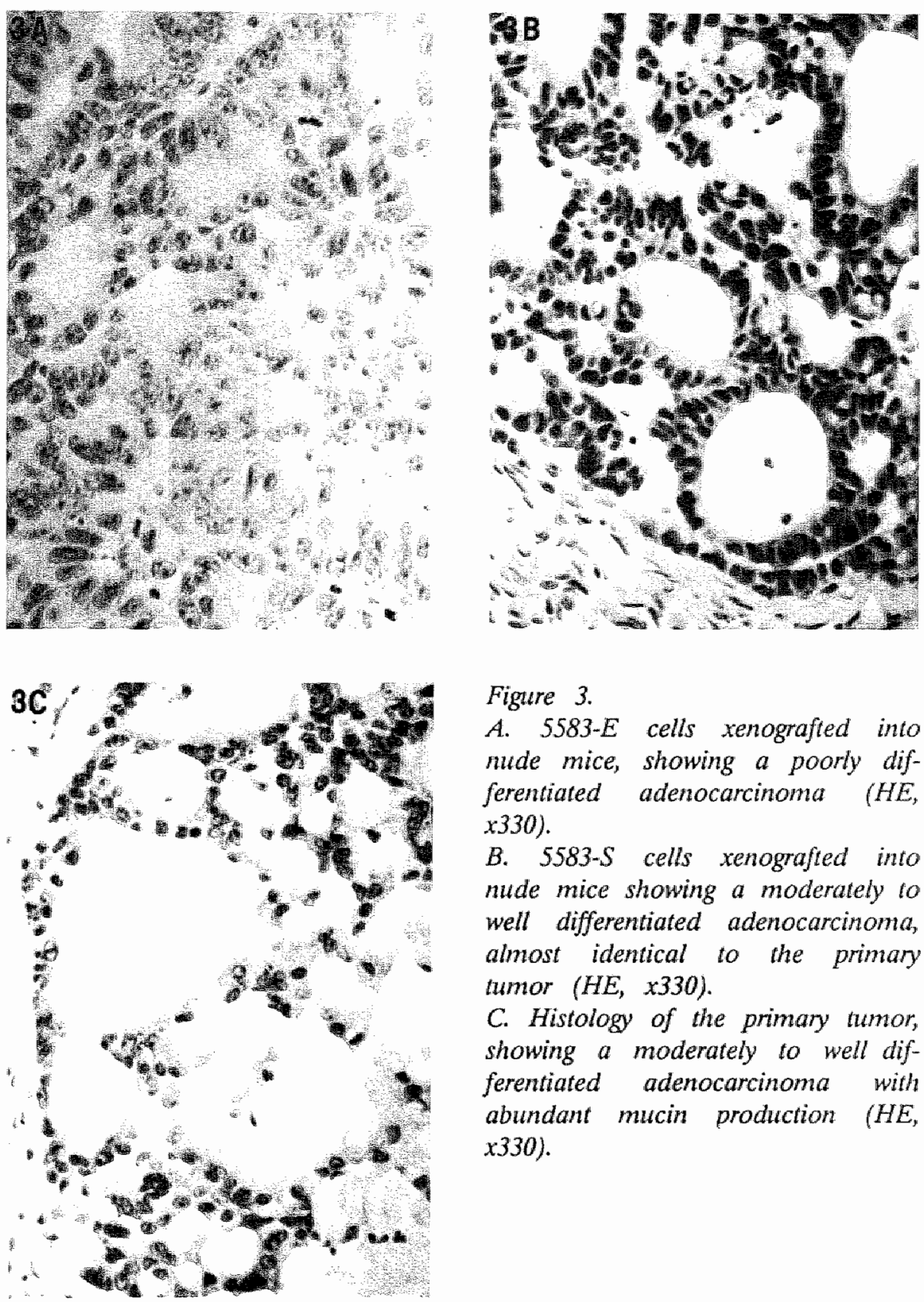

Figure 3.

A. 5583-E cells xenografted into nude mice, showing a poorly differentiated adenocarcinoma (HE, x330).

B. 5583-S cells xenografted into nude mice showing a moderately to well differentiated adenocarcinoma, almost identical to the primary tumor (HE, x330).

C. Histology of the primary tumor, showing a moderately to well differentiated adenocarcinoma with abundant mucin production (HE, x330). 
Table III. Expression of differentiation markers in the primary tumor, 5583-S and 5583-E cells and their xenografts.

\begin{tabular}{lcccc}
\hline & SC & CEA & sialomucin & sulphomucin \\
\hline Primary tumor & + & + & + & + \\
$5583-S$ cells in vitro & + & + & + & + \\
$5583-S$ xenograft & + & + & + & + \\
$5583-$ E cells in vitro & + & - & + & + \\
$5583-$ E xenograft & + & - & \pm & \pm \\
\hline
\end{tabular}

$\begin{aligned}+\quad & =\text { strong expression } \\ \pm \quad & =\text { weak expression } \\ & =\text { no expression }\end{aligned}$

mucin production. In contrast 5583-E cells only showed scanty mucin production. In the primary tumor most of the mucin was of sialomucin typc, sulphomucins occurring only focally. In 5583-S cells (in culture and xenografts), however, extensive sialomucin and diffuse sulphomucin production was found. The expression of differentiational markers was studied at various time intervals after initiation and no apparent changes in the pattern of expression nor in the growth patterns were observed.

\section{Electronmicroscopy}

Fig. 4 illustrates the ultrastructural features of 5583-E cells, cultured on amniotic membranes. The cells grew in monolayered sheets. Individual cells frequently did not show polarity, with a central location of the nucleus and randomly distributed cytoplasmic organelles. The cell surface showed scant microvilli. Intercellular connections were well developed. Mucin granules did occur but not in large numbers.

Fig. 5 illustrates the ultrastructural features of 5583-S cells. These cells frequently grew in monolayer sheets, surrounding a central lumen. The columnar shaped cells usually showed distinct polarity with basal location of the nucleus, supranuclear concentration of cytoplasmic organelles including numerous mucin granules (5A), and well developed microvilli on the luminal cell surface (5B). 


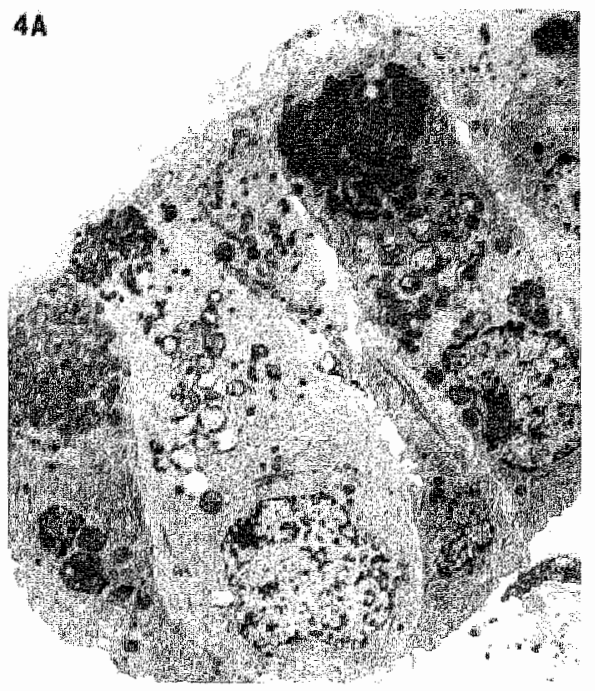

$5 \mathrm{~A}$
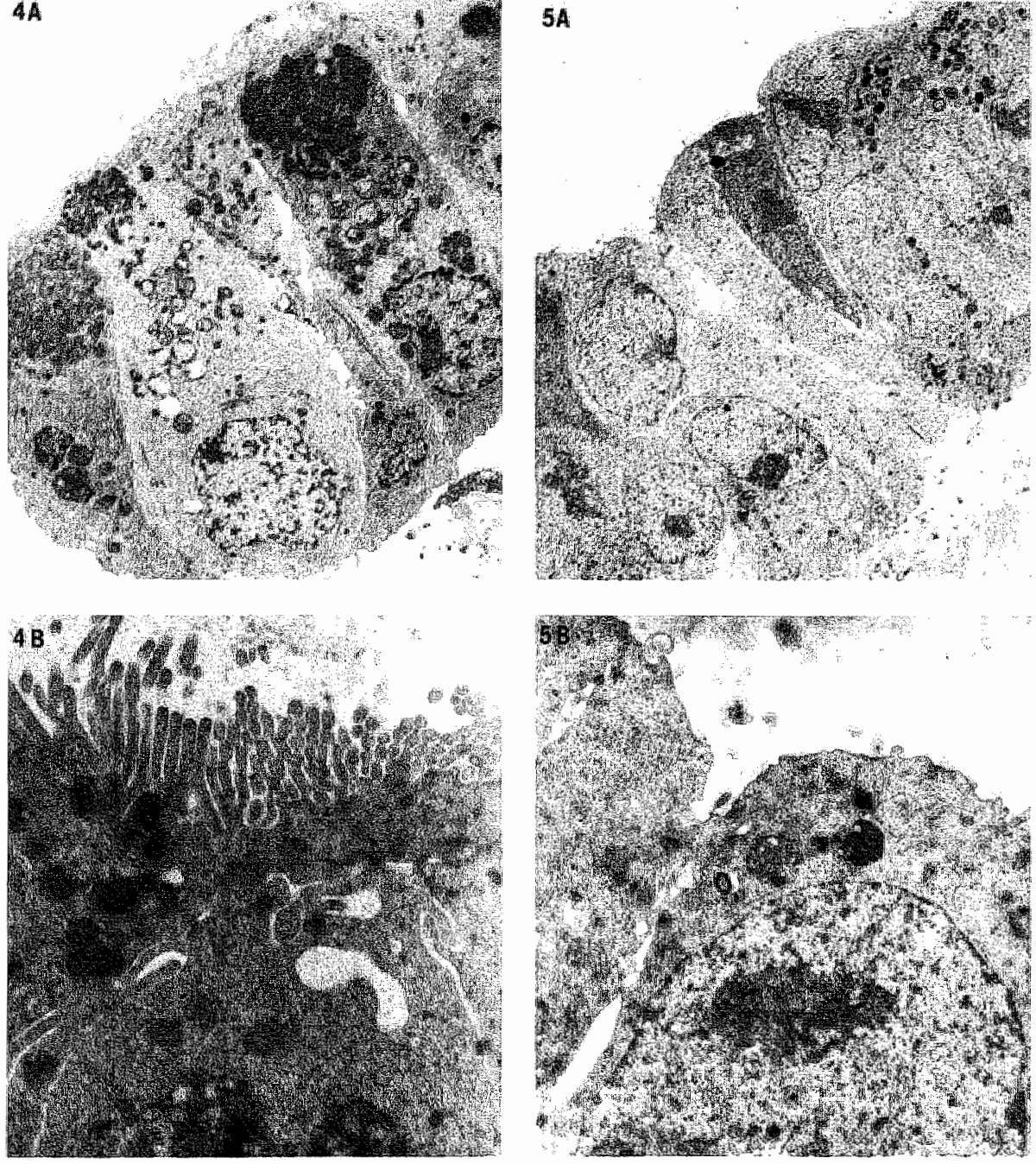


\subsection{Discussion}

The existing morphological subdivisions of colorectal carcinoma correlate poorly with their biological and clinical behaviour so that biologically and clinically relevant new subdivisions are urgently needed. To achieve this, many groups have studied the biology of colonic carcinoma cells in vitro or xenografted into athymic mice. These studies have resulted in a multitude of cell lines with widely different characteristics (1-10, 18). However, individual cell characteristics which consistently predict the behaviour of the corresponding tumor in vivo in terms of invasive growth and metastatic property have not been identified so far.

Several groups of investigators have proposed classifications of colonic carcinoma cell lines, based on light microscopical and ultrastructural evidence of differentiation, chromosome number, tumorgenicity in athymic mice, CEA production, growth rate and cell kinetic characteristics $(6,7,19)$. However, conflicting findings have been reported. Brattain et al. (6) found that cell lines with high clonogenicity and growth rate led to morphologically undifferentiated tumors when transplanted into athymic mice. In contrast Drewinko et al. (19) reported that cell lines resulting in undifferentiated tumors had low clonogenicity and growth rate. These results illustrate that unequivocal correlations between the various characteristics do not exist and underline the fact that more detailed analysis of the biological characteristics of colonic carcinoma cells in relation to the clinical behaviour of the tumor is urgently needed. For this purpose, a a wider variety of cell lines and more detailed characterization of their in vivo behaviour is necessary. We have oblained two new cancer cell lines from a primary colonic adenocarcinoma. 5583-S cells grow in suspension, are not clonogenic in soft agar and form moderately to well differentiated lumors in athymic mice. 5583-E cells grow in epithelial cell-layers, are clonogenic in soft agar and form poorly differentiated tumors in athymic mice. $5583-\mathrm{S}$ cells have a longer doubling time than 5583-E cells and, in contrast to the latter, produce mucin and CEA. These variant cell lines share some characteristic numerical and structural chromosomal

4 Figure 4. Ultrastncture of 5583-E cells grown on amniotic membranes (A. $\times 2960 ; \quad B: x 10800)$

4 Figure 5. Ulrastuchure of 5583-S cells (A: x3840; B: x18000). 
abnormalities (marker chromosome and trisomy 12 and 14) but differ in others (the isochromosome $1 \mathrm{q}$ is present only in 5583-E). A remarkable feature of 5583-S cells is their spontaneous growth in suspension and abundant mucin production. These results support the concept that within a single tumor, multiple variant cell clones can exist. It is tempting to speculate on the basis of the karyotypic difference between 5583-S and 5583-E that genetic mechanisms play a role in the generation of tumor cell heterogeneity. It is also clear, however, that differentiational phenomena partly create the apparent morphological heterogeneity. This is well illustrated by the occurrence of $\mathrm{SC}$ immunoreactive columnar cell-like, as well as mucin producing goblet-like cells in 5583-S. Apparently in 5583-E cells the goblet cell characteristics were largely lost. 


\section{References}

1. Rutzky LP, Kay CI, Siciliano MJ, Chao M, Kahan BD. Longitudinal karyotype and genetica signature analysis of cultured human colonic adenocarcinoma cell lines. LSISO and LS174. Cancer Res, 1980, 40: 1443-1448.

2. Brattain $M G_{*}$ Fine WD, Khaled FM, Thompson J, Brattain DE. Heterogeneily of malignant cells from a human colonic carcinoma. Cancer Res. 1981b, 41: 1751-1756.

3. Dexter DL, Spremulli EN, Fligiel $Z$, Barbosa JA, Vogel $R$, Van Voorhees $A$, Calubresi $P$ Heterogeneity of cancer cells from a single human colon caircinona. Arm. J. Med. 1981, 71: $949-956$.

4. Spremulli EN, Scotl C, Campbell DE, Libbey NP, Shochat D, Gold DV, Dexter DL. Characterizat tion of two melastatic subpopulations originating from a single humatio colon arcinoma. Cancer Res. 1983, 43: 3828.3835.

5. Brattain $M G$, Brattain DE, Fine WD, Khaled FM, Marks ME, Kinball PM, Arcolano LA, Danbury BH. Initation and characterization of cultures of human colonie carcinoma with different biological characteristics utilizing feeder layers of contuent fibrolatasts. Oncodevelopmental Biol. and Med. 1981a, 2: 355-366.

6. Brattain $M G$, Levine $A E$, Chakrabarty $S$, Yeoman $L C$ Willson JKV, Lorug $B$, Heterogeneity of human colon carcinoma. Cancer Matast. Rev. 1984, 3: 177-191.

7. Leibovitz A, Stinson JC, McCombs WB, McCoy CE, Mazur KC, Nabry ND. Classilucation of human colorectal adenocarcinoma cell lines. Cancer Res. 1976, 36: 4562-456\%.

8. Namba $M$, Miyamoto $K$, Hyodoh $F$, Iwama $T$, Utsunomina J, Fukushima $F$, Kimoto $T$. Establishment and characterization of a human colon carcinoma cell line (KMS-4) from a patient with hereditary adenomatosis of the colon and rectum. Int. J. Cancer 1983, 32: 697-702.

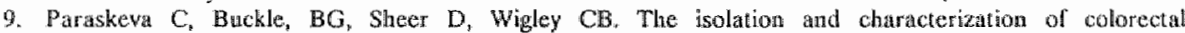
epithelial cell lines at different stages in malignant transformation fron familial polyposis coli patients. Int. J. Cancer 1984, 34: 49-56.

10. Kirkland SA. Dome formation by a buman colonic adenocarcinoma cell ine (HCA-7) Cancer Res. $1985,45: 3790-3795$.

11. Augeron $C_{2}$ Laboisse $C L$. Emergence of permanently differentiated cell clones in it hunan colonic cancer cell line culture after treatment with sodintm butyrate. Cancer Res. 1984, 44: $396:-3969$.

12. Liotla LA, Lee CW, Morakis DJ. New method for preparang large surfaces of intact human basement membrane for tumor invasion studies. Cancer Lefters 1980, 11: 1.41-152.

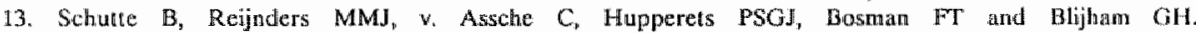
Studies with anti Bromodeoxyuridine anuibodies. 1. An improved method for anamunocylo* chemical delection of Brolurd lisbeled nuclei using Aowcytometry. Cyometry (198\%, an Press.).

14. Begg AC, McNally NJ, Shricve DC Karcher H. A trethod to measure the duration of DNA syathesis and the potential doubling time from a single sample. Cytometry $19855_{n} 6: 620$ 626 .

15. Hamburger AW, Salmon SE. Primenry bioassay of human myeloma stlen cells. I. CHin. Inweght 1977, 60: 846.

16. Arends JW, Verstijinen C, Bosman FT, Hilgers J, Steplewski Z. Distribution of monoclonal antibody-defined monosialoganglioside in normal and cancerous hunath lisstes: an immuneperoxidase study. Hybridoma $1983,2: 219-229$.

17. Versijjen CPH.J, Arends JW, Moerkerk PTM, Warnatar S, Hilgers J, Bosman FT. CEA-specillicily of CEA-reachiwe nonoclonal antibodies. Innunochemical and immunocyochemical stadies. Anticancer Res. 1986, 6: 97-104.

18. McBain JA, Weese $2 \mathrm{~L}$, Meisner LF, Wolberg WH, Willson JKV. Esta btishment and characturization of human colorectal cancer cell lines Cancer Res. 1984, 44: 5813-5821

19. Drexwinko B, yang LY, Leibovitz A, Barlogie B, Lutz D Jansson B, Stragand dJ, Trujillo MM. Cellular discriminants for a biological classification of himan colon carcinomian Cancer Res. 1984, 44: $4241-4253$. 
GENERAL DISCUSSION 
Colorectal carcinoma is one of the most frequently occurring types of cancer in the western world with an annual incidence in the Netherlands of aproximately 6.000 cases per year. There are two main reasons to adress more attention to the study of the biological behaviour of the disease. In spite of improvements in the surgical techniques, methods of radiatiotherapy and chemotherapeutic regiments, the prognosis of colorectal cancer has not improved significantly over the last decades. An important reason for this relative failure is that many patients initially present with already incurable disease, due to extensive spread of the neoplasm. A second important aspect is that tumors that morphologically and in terms of extension are quite similar nevertheless may behave rather different.

For colorectal carcinoma the best available prognostic indicator as yet appears to be the stage of the tumor which is commonly expressed in the Dukes classification. However, within one single Dukes stage the clinical behaviour of the disease is by no means uniform. Reliable morphological descriptors, which allow a distinction (within a single Dukes category) between cases that will show a favorable and those that will show an unfavorable outcome, are not available. A conventional approach to this problem has been histological grading of the tumor in colorectal carcinoma according to Blenkinsopp (1) into well, moderately and poorly differentiated neoplasms. Tumor grade has been shown to provide some useful prognostic information (1) but clearly does not represent the final solution to the basic problem. Its assessment is a matter of subjective judgement and the results therefore lack reproducibility, to which the occurrence of tumor heterogeneity contributes significantly. Finally, as is often the case in grading systems with three grades, the middle grade is by far the largest and houses very different neoplasms. This limits the significance of tumor grade as a prognostic parameter. Consequently, many attempts have been made to recognize additional variables that might be useful as prognostic indicators. For this purpose at the cell- and tissue level several approaches have been used.

Firstly, inmunocytochemical analysis of the expression of tumor associated antigens has been performed. Examples of this approach are e.g., CEA and $\mathrm{Ca} 19-9$ antigen. CEA has been extensively studied at the tissue level. Variable results with regard to its prognostic significance have been reported (2-4). Our own experience in this regard has been rather unfavorable. Our group has reported the occurrence of a small subgroup of cases with almost purely membrane 
bound CEA immunoreactivity, which showed a somewhat better prognosis (5). One of the problems with CEA, however, is the extensive crossreactivity of polyclonal antibodies with crossreacting antigens. Therefore we have attempted to generate monoclonal antibodies, that might show a more restricted reactivity, excluding reactivity with crossreacting antigens and hopefully showing some tumor and potentially even organ specificity. Our experiences as described in chapter II-2 indicate that it is not very likely that the CEA molecule houses tumor- or organ specific epitopes. Our results indicate that the crossreactivity with crossreacting antigens is probably caused by complex epitopes which are partly shared and partly specific for either CEA or the crossreacting antigens, which limits the possibilities of generating purely CEA reactive monoclonal antibodies. More will become known in the near future about CEA, however, as the CEA gene has been cloned recently $(6,7)$.

Our experiences with the $\mathrm{Ca} 19-9$ antigen have been rather similar. The experiments described in chapter II-3 illustrate that contrary to the initial claims the $\mathrm{Ca} 19-9$ antigen is not tumor specific, not specific for the gastrointestinal tract, and therefore at the tissue level might not contribute to the diagnosis of colorectal carcinoma. We have subsequently explored the use of Ca 19-9 reactivity as a prognostic indicator and have reported elsewhere that a small subgroup of $\mathrm{Ca}$ 19-9 reactive tumors could be identified with a slightly worse prognosis (8). However, the significance of Ca 19-9 as a prognostic indicator remains rather limited.

A second type of attempt has been the definition of differentiation in the neoplasm by immunocytochemical detection of differentiation markers. In this context among others secretory component, neuroendocrine characteristics and mucin production have been tested. Our own group, as well as other investigators, have shown that these differentiation markers may convey prognostically significant information (3, 9-12). In this context we have reported that SC immunoreactivity identifies a small subgroup of patients with a more favorable prognosis (9) and in contrast serotonin immunoreactivity identifies a small subgroup of patients with a worse prognosis (10). Our experiments with mucin typing has also been interesting in that predominantly sulphomucin producing tumors appear to behave more favorably than predominantly sialomucin producing neoplasms (11). The experiments described in chapters II.4 and II.5 were directed towards the development of additional parameters to identify differentiation characteristics in colorectal neoplasms. As has been reported by several other groups 
(13-15), monoclonal antibodies can be generated to mucin antigens. Likewise, we have generated a small library of monoclonal antibodies reactive with four categories of mucin-related epitopes, which were defined on the basis of the characteristics of the associated antigens as well as their immunohistochemical localization. As differentiation towards mucin producing (goblet) cells is an important general aspect of colorectal carcinoma, such a library of antibodies might allow a better definition of this line of differentiation. Our suggestion that the monoclonal antibodies might define mucin-related glycoproteins in various phases of posttranslational modification would fit the required characteristic of a monoclonal antibody that would help defining stages of differentiation. Clearly, the experiments described in this chapter need to be further elaborated. Application of these monoclonal antibodies to collection of well documented colorectal cancer cases might establish their value as prognostic indicator in large bowel carcinoma.

Although tumor associated- and differentiation antigens have been shown to convey some prognostically significant information, its importance has proven to be rather limited, especially when tested in a multivariate regression analysis (16). By and large, none of these descriptors show a better discriminating power than the Dukes' classification, although some of them do show a statistically significant correlation with patient survival, In hindsight, this is not at all surprising, given the fact that these markers all identify characteristics of terminally differentiated cells. We suggest that terminally differentiated cells do not proliferate and do not ultimately determine the behaviour of a tumor. The cells with the highest proliferative potential, the tumor stem cells, would represent the most important cells in a neoplasm. If after subcurative therapy even a single stem cell would remain, this cell would be able to repopulate the tumor completely. Therefore, elimination of the non stem cells, which in most tumors probably constitute the majority of neoplastic cells, would never result in curation. If the stem cell model for carcinoma is correct, it would be of tremendous importance to be able to recognize the stem cell and to understand its biology.

Against this background it seems obvious that the development of a new system for classification of colorectal carcinomas that is biologically valid as well as clinically relevant, is urgently required. Biological validity might be based upon a unifying concept of proliferation and maturation of normal colonic epithelial cells. In contrast to the situation in hematopoietic and lymphoid tissues, however, 
basic concepts regarding cellular proliferation and differentiation in parenchymous epithelial cell types are almost completely lacking. For colonic mucosa the presently held wiews regarding epithelial cell maturation were originally formulated by Cheng and Leblond (17). They provided evidence that all cell types are derived from the same precursor cell which they postulated to be the crypt base columnar cell. This so-called unitarian theory was subsequently corroborated by biological studies, using the quail chicken neural crest transplantation technique (18). Detailed knowledge, concerning the relation between the three cell lineages in the colorectal mucosa (columnar cells, goblet cells and endocrine cells), e.g. in regard of the point in the differentiation process at which they segregate, or how long they keep their proliferative potential, are completely lacking. If such information was available, conceivably a classification system might be designed, which reflects the normal patterns of proliferation and differentiation in colorectal epithelium, comparable to the presently used classification systems of malignant lymphoma.

In order to attain this goal, however, model studies are needed in order to gather more fundamental knowledge concerning the patterns of differentiation in normal colonic mucosal epithelium and in colorectal carcinoma cells. The development of model systems and some examples of their use is described in chapter III. In chapter III.2 the implantation of colonic mucosa in athymic mice is described. Subsequent to reports of others on the possibilities to xenograft normal human epithelia, such as breast (19), and endometrial mucosa (20) we attempled to xenograft colonic mucosa in nude mice. Our experiments show that this approach might be used in order to gain a better insight in the regulation of differentiation and proliferation in colonic mucosa. In such a model various factors which influence proliferation and differentiation, such as hormones and growth factors might be studied. Furthermore it might be feasible to use this model to study factors that cause abnormal colonic growth and to induce neoplastic alterations by carcinogens.

The use of the in vitro culture model and of the nude mouse model for the study of the biology of colorectal carcinoma is described in chapter 1113. These studies show that in vitro as well as in vivo colorectal carcinoma cells can be maintained but also highlight the limitations of this approach. Limitations of the models are that not all tumors can be succesfully cultured or grafted and our study indicates that there is a selection of tumors with metastatic 
capacity and tumors of the proximal colon. In general, morphological, celbiological and molecular biological features of original tumors appear to be maintained in nude mouse models over very long periods of time. These models may therefore be of crucial importance in solving the core questions concerning colorectal carcinoma: what determines invasive potential, which mechanisms are involved in metastases, is metastasis a selective process, is tumor progression due to selection of various subclones and finally, is therapy resistence due to selection.

Invasive potential is one of the most essential characteristics of malignant neoplasia. As yet, the mechanisms of invasive growth have not been completely elucidated. Aspects that have been studied sofar concern the deposition and degradation of basement membrane material $(21,22)$, epithelial cell interaction with mesenchymal stroma $(23,24)$ and the influence of growth factors on these characteristics (25). Most of these studies revealing components determining invasive potential were performed in vitro: by tissue culture on amniotic basement membrane (26), in reconstituted basement membrane material in Boyden chambers (27) or on embryonal chicken heart tissue (28).

Metastasis can be studied in in vivo models (29). It has been repeatedly shown that the occurrence of metastases in nude mouse xenografts is determined by the site of grafting (30). What exactly determines whether or not xenografted tumor cells metastasis and how these cells will metastasize remains unknown to date. As in colorectal carcinoma hepatic metastases probably are the main cause of death, such knowledge would also be of paramount importance in solving the main clinical problems in colorectal cancer.

Progression is also a characteristic feature of malignant neoplasms. Progression indicates the phenomenon that a neoplasm does not remain constant in time but, presumably as a consequence of the sequential appearance of subpopulations (31), may show evolution of different patterns of biological behaviour as shown in chapter III.5. The existence of the resulting cellular heterogeneity adds a new dimension to the understanding of the natural history of tumors in terms of invasion, metastatic propensity and therapy resistence $(30,32)$. The existence of different subpopulations increases the chance that cells with a high probability to survive will be selected and may thus facilitate invasion, metastasis and the occurrence of therapy resistence (33). In vitro and in vivo model systems will be important tools to study mechanisms of tumor progression (32). In these model systems the influence of growth factors, growth 
factor inhibitors or differentiation promotors on tumor cell behaviour might be studied (34). Such an approach might eventually lead to a more rational approach to chemotherapy, implying the correction of deviant proliferative behaviour rather than eradication of deviant cells. 


\section{References}

1. Elenkirsopp WK, Stewart Brown S, Blensovgly L, Kearney G, Fieldberg LP. Histopathology reporting in large bowel cancer. I. Clin. Pathol 1981, 34: 509-513.

2. Abnen DI, Naksine PK, Brown WR. Ultrastructural lacalization of carcinoembryomic antigen in normal intextine and collon cancer. Cancer 1982, 49: 2077-2090.

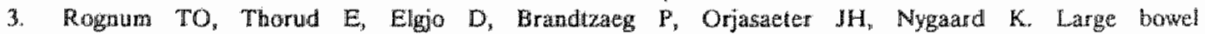
carcinomas with different ploidy, related to secretory component $\lg A$ and CEA in epithelium and plasma. Br. J. Canocer 1982, 45: 921-934.

4. Hamada $Y$, Yamamura M, Hioki K, Yamamoto M, Nagura $H$, Watanabe K. Immunohisicochemical sidudy of carcinoembryonic antigen in patients with colorectal cancer. Cancer 1985 , 55: 136-141.

5. Wiggers $T$, Arends JW, Vertijnen C, Moerkerk PM, Bosman FT. Prognostic significance of CEA immunoreactivity paterns in large bowel carcinoma lissuc. Br. J. Cancer 1986, 54: 405914 .

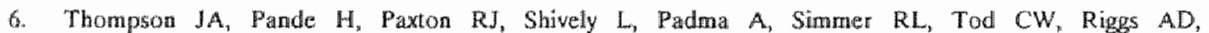
Shiviely JE. Molecular ctloning of a gene belonging to the carcinoembryonic antigen giene lamily and discussion of the domain model. PNASS 198\%, 84: 2965-2969.

7. Zimmerman $W$, Ortleb $B$, Friedrich $R$, Von Kleist $\$$. Isolation and characterization of CDNA clones encoding the human carcinoembryonic ancigen reveal a highly conserved repeating structure. PNASS 1987, 84: 2960-2964.

8. Arends JW, Wiggers $T$, Versijnen $C$, Hilgers $J$, Bosmam FT. Gastrointestinal cancer ässociated antigen (GICA) immunoreactivity in colorectal carcinoma in relation to patients surwiwal. Int. J. Cancer 1984, 34: 193-196.

9. Arends JW, Wiggers T, Thijs CT, Werstijnen C, Swaen GJV" Bosman FT, The value of secretory componen (SC) immunoreactiwity in diagnosis and prognosis of colorectal cancer. Am. J. Clin. Pathol, 1984, 82: 267-274.

10. Arends JW, Wiggers $\mathrm{T}$, Verstijnen C, Bosman FT. The occurrence and clinico pathological significance of serotonin immunoreactive cells in large bowel carcinoma. $\int$. Pathol. 1986, 1.49: 97.102 .

11. Arends JW, Wiggers T, Verstijnen CPHJ, Bosman FT. Chinicopathological and prognostic significance of sulpho sialomucin production in large bowel carcinoma. Submitted.

12. Istacson P. Immunoperoxidase study of secretory immunoglobulin system in colonic neoplasia. J. Clin. Pathol. 1982, 34: 14-25.

13. Hughes NR, Walls RS, Newland RC, Payne JE. Antigen expression in normal and neoplastic colonic mucosas three tissue specific antigens using monoclonal antibodies to isolated colonic gilands. Cancer Res. 1986, 46: 2164-2171.

14. Hodolsky DK, Fonrnier DA, Lynch KE. Development of anti-buman colonic mucin monocionall andibodies. Characterization of multiple colonic macin species. J. Clin. Invest. 1986, $77_{*}$ $1251-1262$

15. URinhman PI, Bodmer WF. Monoclonal antibodies to buman colorectal epithelium: markers for differentiation and immor characterization. Int. J. Cancer 1987, 39: 317.328.

16. Wiggers $T$, Arends $J W$, Schute $\mathrm{D}$, Volovics $\mathrm{L}$, Bosman FT. A multivariate analysis of pathological prognostic indications in large bowel cancer. Cancer (in press).

17. Cheng $H$, Leblond $C P$. Origin and diffenentiation and renewal of the four mair epithelial cell types in the mouse small intestine. $V$. Unitarian theory of the origin of the four epilhelial cell types. Am, J. Anat, 1971 , 141 : 537-562.

18. Fontame J, Le Douarin NM. Analysis of endoderm formation in the avian blastoderm by the use of quail-chick chimaeras. The problem of neuroectodermal origin of the cells of thic APUD series. I. Embryonal Exp. Morph. 1977, 41: 209-222.

19. Dubois JD, O'Hara MJ, Gusterson BA. Evidence for lactation in huram breast organoid xenogratts being independent of local mammary factors. J. Pathol 1986, 148: 98A-99A.

20. Bergquass $A$, Jeppsson $S$, Kullander $S$, Ljungberg $O$. Human endometrium transplanted into mude mice. Histological elfects of various steroid hormones. Ann, J. Pathol. 1985, 119: 336344.

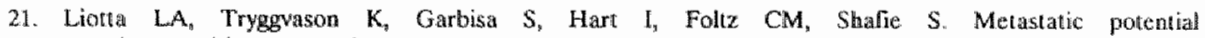
correlates with enzymatic degradation of basement membrane collagen. Nature 1980, 284: 67-68. 
22. Zucker S, Wheman JM, Lysik RM, Wilkie D, Ramamurthy NS, Golub LM, Lane B. Enrichment of collagen and gelatin degrading atcivities in the plasna membranes of hunutu cancer cells. Cancer Res. 1987, 47: 1608-1614.

23. Lioulia LA. Tumor invasion and metastases; role of the basement membrane, Aun. J. Pathol. 1984, 117: 339-348.

24. Hemry N, Eechhout $Y$, Van Lamsweerde AL, Vaes G. Coroperation between metastatic lumor cells. and macrophages in the degradation of basement membranes. FEBS 1983, 161: 243m 256 .

25. Wigley $\mathrm{CB}$, Paraskeva $\mathrm{C}$, Coventry R. Elevated production of growh factor by human premalignant colon adenomas and a derived epithelial cell line. Br. J. Cancer 1986, 54 $799-805$

26. Lionta LA, Lee $\mathrm{CW}$, Morakis $\mathrm{DJ}$, New method for preparing large surfaces of imtact hunuar basement menabranes for tumor invasion studies. Cancer Let. $1980,11: 141-152$.

27. Terranova VP, Hic S, Diflorio RM, Lyall RM. Tumor cell metastasis. CRC Critical Reviens in Oncology Hentatology $1985,5: 339-348$.

28. Mareel MMK. The use of embryo organ cullures to study inwasion in vitro. In: Lionta LA. Hart IR (eds.) Tumor invasion and metastasis. 1982 Marimus Nijhot Pulalishers, "The Netherlands.

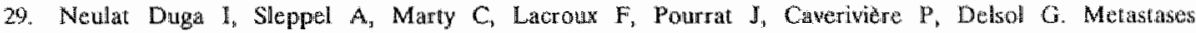
of human tumor xenografts it nude mice. Inwasion and metastasis 1984, 4: 209-224.

30. Fidler II. Rational and methods for the use of mude mice to study the biobogy and therapy of human carcer metastasis. Cancer Metast. Rev" 1986, 5: 29-49.

3i. Nicolson GL. Tumor cell instability diversification and progression to the metasiatic phenotyje: from oncogene to oncofettal expression. Cancer Res. 1987, 47, 1473-1487.

32. Harris CC. Human tissues and cells in carcinogemesis resestch. Cancer Res. 1087, 47. 110.

33. Nicolson GL, Brunson KW, Fidler $1 \mathrm{H}$, Specificity of arrest, survival and growh of selected molastatic varuant cell lines. Cancer Res. 1978, 38: $4105-4111$.

34. Crotstin AS, Lef EB, Shipley GD, Moses HL Growth finctors and cancer. Cancer Res. 1986, 46: $1015-1029$. 


\section{SUMMARY}

This thesis describes attempts to characterize colorectal carcinoma cells in vitro by immunohistochemistry, tissue culture and in vivo in nude mouse xenografting. The background of these studies is that colorectal carcinomas have a diverse and relatively unpredictable course. The Dukes stage (extent of the disease) and grade (histological characteristics) have been used as prognostic and diagnostic parameters. The significance of these parameters is limited, however, because some patients with limited disease (e.g. Dukes A) or high grade (well differentiated) do show rapidly progressive disease with a fatal outcome. Phenotypic characterization of colorectal carcinoma by means of immunocytochemical techniques may be more accurate and objective for histological grading. Especially tumor specific antigens would be of enormous diagnostic significance. However, tumorspecific antigens have so far not been detected. The studies on Mo Abs to CEA were undertaken to investigate the possibility that tumor specific epitopes might exist in these molecules. Chapter II-2 describes the development and characterization of these Mo Abs against CEA. The epitopes of Mo Abs PARLAM 1, 5 and 6 appeared to occur on CEA but also on various crossreacting antigens such as biliary glycoprotein, normal crossreacting antigen and normal fecal antigen. PARLAM 4, specific for CEA in biochemical tests, showed a weak reactivity with normal liver and spleen tissue, which indicated that low affinity binding of the Mo Ab to a crossreacting epitope occurs. Tumorspecilicity was not found. According to these findings a complex model for the occurrence of crossreacting antigens and epitopes of CEA was proposed. The immunohistochemical exploration of another tumor associated antigen, the Ca 19-9 antigen (Chapter II-3), showed that also this antigen was not tumor specific as it was present in non neoplastic, glandular epithelia. It was furthermore found in carcinomas outside the gastrointestinal tract and therefore lacks both tissue and tumor specificity.

Immunohistochemical evaluation of colon cancer could, as an alternative, also involve the detection of differentiated antigens, which might allow a more refined histological grading. Chapter II-4 and II-5 deal with the generation characterization and tissue distribution 
of eight Mo Abs against mucin antigens of high molecular weight. According to biochemical characteristics and localization in normal colonic mucosa they can be divided into four groups. Mo Abs of the first group (PARLAM 3, 9, 10) detect an epitope on an $87 \mathrm{kD}$ protein subunit of a mucin molecule which is present in the cytoplasm of goblet cells. The second group (PARLAM 8, 12 and 13) reacts with a carbohydrate epitope on a mucin molecule present mainly in the supranuclear cytoplasm (probably the Golgi complex) of goblet cells in normal colon. PARLAM 2 represents the third group showing a focal, coarse granular goblet cell staining in colon. The fourth group consists of PARLAM 11, which reacts with the normal colonic brush border. From studies on fetal intestinal, normal colonic, preneoplastic colonic and neoplastic colonic tissues and a variety of non intestinal normal and neoplastic tissue specimens one can conclude that PARLAM 3, 9 and 10 can be used to investigate the significance of goblet cell characteristics in colonic neoplasia.

PARLAM 8,12 and 13 can be used to study altered glycosylation of mucins in premalignant and malignant colonic epithelium. PARLAM 11, which detects a columnar cell brush border mucin in colon, but not in small intestine can be used to study colonic brush border differentiation.

The immunocytochemically determined antigen expression in neoplasms provides only a momentous view on the biology of the lesion at the time of resection. Carcinogenesis is, however, a dynamic evolutionary process. Since the origin and development of colorectal neoplasm may partly follow the lines of normal colonic differentiation it would be of value to identify characteristics of various stages of differentiation and maturation. But also of normal human colonic epithelial development only fragmentary knowledge exists. In vivo and in vitro models are necessary to allow investigation of the processes of normal and neoplastic development. Chapter III-2 describes a technique for xenografting of normal human colon mucosa into nude mice. The xenografts maintain normal proliferating and differentiating characteristics for at least 5 weeks. This technique allows the study of factors that influence normal colonic growth and differentiation and conceivably also some of the factors which are involved in colonic carcinogenesis.

The in vitro culture and in vivo xenografting of colonic carcinomas, as described in Chapter III-3, show that standard procedures of tissue culture and xenografting are successfully applied in approximately $30 \%$ of the primary colorectal carcinomas. A relatively higher successrate 
was found in tumors which had already metastasized and tumors at the proximal colon. This study has shown that in general xenografts do resemble the original primary tumor, although morphologically and by marker expression they often resemble less differentiation areas of the primary tumor. In terms of DNA index the grafts were usually identical to the primary tumor, although occasionally a stemline was lost or a new stemline was gained. An interesting finding was the cell line 7248, which was produced from a severely dysplastic but non-invasive adenoma, demonstrating that cell lines can also be obtained in early phases of the development of the malignant process. The culturing of tumors of different stages of the malignant process may shed some light on the various steps which occur during the carcinogenic process in time.

Chapter III-5 deals with the establishment and characterization of two different cell lines from a single colonic carcinoma. The cell lines differed in phenotypic as well as genotypic characteristics. This shows thàt multiple cell lines can be obtained from one tumor. These results are important for the understanding of the phenomenon of tumor heterogeneity, which is clinically relevant in regard of radio- and chemotherapy resistance.

In the general discussion the results are evaluated against the background of the available knowledge concerning the biology of colonic carcinoma. It is concluded that further studies should concentrate on the developmental biology of colorectal mucosal epithelium and on the applications of such knowledge for the development of new biologically valid as well as clinically relevant classifications of colorectal carcinoma. 


\section{SAMENVATTING}

In dit proefschrift worden pogingen beschreven om colorectale kanker cellen met behulp van immunohistochemische kleuringen in vitro, met weefselkweek en in vivo in naakte muizen xenografts te karakteriseren. De achtergrond van deze studie is dat colorectale carcinomen een onvoorspelbaar verloop hebben. De Dukes stagering (uitbreiding van de ziekte) en de gradering, (histologische karakteristieken) worden als prognostische en diagnostische parameters gebruikt. De waarde van deze parameters is echter beperkt doordat sommige patienten met een geringe uitbreiding van de ziekte (b.v. Dukes A) of met hoge gradering (goed gedifferentieerd) een snelle progressie van de ziekte vertonen met een fatale afloop. In een poging de histologische gradering te verbeteren kunnen fenotypische kenmerken bestudeerd worden met behulp van monoclonale antistoffen die toegepast worden in immunohistochemische kleuringen. Tumorspecifieke antigenen zouden van uitermate grote diagnostische betekenis kunnen zijn. De bedoeling van de bestudering van monoclonale antilichamen gericht tegen CEA was na te gaan of in dit molecuul tumorspecifieke epitopen voorkomen. In hoofdstuk II-2 wordt de ontwikkeling en karakterisering beschreven van deze monoclonalen gericht tegen CEA. De epitopen van de monoclonale antilichamen PARLAM 1, 5 en 6 bleken zowel op CEA als op verschillende kruisreagerende antigenen zoals o.a. gal glycoproteine, normaal kruisreagerend antigeen en normaal fecaal antigeen voor te komen. PARLAM 4, dat in biochemische test speciliek is voor CEA, vertoonde een zwakke binding met normaal milt en lever weefsel, hetgeen duidde op een laag affiene binding van het monoclonaal mel een kruisreagerend epitoop. Tumor specificiteit werd niet aangetoond. Naar aanleiding van deze bevindingen werd een complex model opgesteld met betrekking tol bet voorkomen van kruisreagerende antigenen en epitopen van CEA. Het immunohistochemisch onderzoek van een andere tumor geassocieerd antigeen, het $\mathrm{Ca} 19-9$ antigeen (hoofdstuk II-3), toonde aan dat ook dit antigeen niet tumorspecifiek was, daar het op normaal klierepitheel voorkwam. Bovendien werd het in carcinomen buiten het spijsverteringskanaal gevonden en miste daarom zowel weefsel- als tumorspecificiteit.

Als een alternatief zou de immunohistochemische evaluatie van colon kanker ook gebaseerd kunnen worden op het aantonen van differentiatie 
antigenen die een gedetailleerdere histologische gradering mogelijk zouden kunnen maken. Hoofdstuk II-4 en II-5 behandelen het maken, karakteriseren en de weefseldistributie van acht monoclonale antilichamen tegen mucine antigenen met een hoog moleculair gewicht. Zij kunnen in vier groepen ingedeeld worden op grond van biochemische karakteristieken en de lokalisatie in normaal colon. De monoclonale antilichamen van de eerste groep (PARLAM 3, 9 en 10) detecteren een epitoop op een $87 \mathrm{kD}$ eiwit subeenheid van een mucine molecuul dat in het cytoplasma van slijmbekercellen voorkomt. De tweede groep (PARLAM 8, 12 en 13) reageert met een koolhydraat epitoop op een mucine molecuul dat hoofdzakelijk aanwezig is in het boven de kern gelegen cytoplasma (waarschijnlijk het Golgi complex) van slijmbekercellen. PARLAM 2 vertegenwoordigt de derde groep. Het monoclonaal vertoont een focaal, grof granulaire slijmbekercelkleuring in de dikke darm. De vierde groep bestaat uit PARLAM 11, dat reageert met een mucine in de borstelzoom van het colon. Uit studies op foetaal intestinaal, normaal colon, preneoplastisch colon en neoplastisch colon en een verscheidenheid van niet intestinale normale en neoplastische weefsels kan afgeleid worden dat PARLAM 3, 9 en 10 gebruikt kunnen worden om de betekenis van slijmbekercelkenmerken in neoplastisch colonweefsel te bestuderen. PARLAM 8,12 en 13 kunnen gebruikt worden om de veranderde glycosylering van mucines in premaligne en maligne colonepitheel te bestuderen. PARLAM 11, dat een columnair borstelzoom mucine in het colon, maar niet in de dunne darm aantoont, kan gebruikt worden om borstelzoom differentiatie van het colon te bestuderen. Deze monoclonale antilichamen kunnen niet alleen gebruikt worden om de slijmbekercel differentiatie en maturatie van het colon, maar ook om de klinische en biologische betekenis van slijmbekercel kenmerken in neoplastische weefsels te bestuderen.

De immunocytochemische bepaling van de antigeen expressie in een neoplastisch weefsel geeft slechis een momentopname van de biologie van de lesie, namelijk van het moment dat deze verwijderd is. De carcinogenese is echter een dynamisch evoluerend proces dat in het normale weefsel begint. Daar de oorsprong en de ontwikkeling van een colorectale tumor een gedeeltelijke afspiegeling kunnen zijn van de differentiatie van het normale colon, is het van belang de karakteristieken te kennen van de differentiatie en rijping van het normale colon. De kennis van de ontwikkeling van normaal humaan colonepitheel is slechts fragmentarisch. Om de in de tijd verlopende processen te bestuderen zijn in vivo en in vitro modellen noodzakelijk. 
Hoofdstuk III-2 beschrijft een techniek om normaal humaan colon slijmvlies in naakte muizen te implanteren. De implantaten behouden tenminste 5 weken de normale proliferatie en differentiatie kenmerken. Deze techniek maakt het mogelijk de factoren, die de normale groei van het colon beïnvloeden, te bestuderen en eventueel ook enkele van de factoren die betrokken zijn bij de carcinogenese van het colon te onderzoeken.

De in vitro kweek en de in vivo implantatie van colon carcinomen, zoals beschreven in hoofdstuk III-3 laten zien, dat standaard weefselkweek en implantatie procedures in ongeveer $30 \%$ van de primaire colorectale carcinomen met succes zijn toegepast. Tumoren die al gemetastaseerd waren en tumoren van het proximale deel van het colon toonden een relatief hogere kans op succes. Deze studie heeft aangetoond dat de xenografts in het algemeen op de oorspronkelijke primaire tumor lijken, hoewel ze morfologisch en wat betreft marker expressie, de meeste gelijkenis vertonen met de minst gedifferenticerde gebieden van de oorspronkelijke tumor. De DNA index van de grafts was gewoonlijk gelijk aan die van de primaire tumoren, hoewel soms een stamlijn verloren ging of een nieuwe stamlijn ontstond. Een interessante bevinding was het feit dat een cellijn, 7248 , van een ernstig dysplastisch, maar niet invasief adenoom gekweekt kon worden. Dit toont aan dat ook cellijnen verkregen kunnen worden van vroege fasen van het maligne proces. Het kweken van tumoren van verschillende fasen van het maligne proces kan licht werpen op de opeenvolgende gebeurtenissen, die plaatswinden gedurende de carcinogenese.

Hoofdstuk III-5 behandelt het kweken en de karakterisering van twee cellijnen uit een colontumor. De cellijnen verschillen in zowel fenotypische als genotypische karakteristieken. Dit toont aan dat meer dan een cellijn uit én tumor kan ontstaan. Deze resultaten zijn belangrijk voor het begrip van het fenomeen tumor heterogeniteit dat van klinisch belang is met betrekking tot resistentic voor radioen chemotherapie.

In de algemene discussie worden de resultaten tegen de achtergrond van de beschikbare kennis wat betreft de biologie van coloncarcinomen geëvalueerd. De conclusie is dat verdere studies geconcentreerd zouden moeten worden op de ontwikkelingsbiologie van colorectaal mucosa epitheel en op de toepassing van die kennis voor de ontwikkeling van zowel nieuwe biologische valide als wel klinisch rellevante classificaties van colorectale carcinomen. 


\section{PUBLICATIELUST}

\section{Full papers}

1. Arends JW, Versilinen $\mathrm{C}_{3}$ Bosman $\mathrm{FT}_{3}$, Higers 3 , Steplewsiki $\mathrm{Z}$ (1983). Distribution of monoclonal antibody derined monosialoganglioside in normal and cancerous buman tissues: an immunoperoxdase study. Hybridom 2: 219-229.

2. Arends JW, Whgers $T$, Sckwte $B$, Thijs $C T$, Verstijen $C_{x}$ Hugers J, Blijham GH, Bosman FT (1983). Monoclonal anibody (1116 NS 19-9) defined monosialoganglioside (GICA) in colorectal carcinomid in relation to stage, histopatholegy and DNA flow cytometry. Int. J. Cancer 32: $289-2993$.

3. van de Rijn M, Geurts van Kessel AHM, Kroezen V, Van Agthoven AJ, Verstijaen K, Terhorst C. Hilgers 1. (1983) Localization of a geme controlling the expression of the human transferrin receptor to the region q12 quer of chromosome 3 .

4. Arends WW, Wiggers $T$, Thijs CT, Verstijnen $C_{1}$ Swaen GJ and Bosman FT (1984). The value of secretory component (SC) immonoreactivity in diagnos as and prognosis of colorectatl carcinomas. Am.J.CLin. Pathol, 82: 267-274.

5. Arends JW, Wiggers $T$, Verstijnen $C$, Hilgers $J$ and Bosman $F T$ (1984). Gastrointestimal cancer-associated antigen (GICA) immunoreactivity in colorectal carcinoma in relation 10. patixent survival. Int. J. Cancer 34: 193-196.

6. Arends JW, Wiggers $T$, Schutte $B$, Thijs $C T$, Verstijnen $C$, Hilgers $d$, Blijham GH and Bosman FT (1984). The value of Centocor Ca 19-9 TM or gastrointestial cancer associated antigeri. (GICA) in the diagnosis and prognosis of colorectal caneer. In: Prot. Biol. Fluids. 31.1984 (Ed. H. Pecters), p. 623-626.

7. Arends SW, Wiggers T, Verstijnen C, Bosman FT, Swaten GXV, Hilgers J, Lennox E, Steplewski $\mathrm{Z}$ (1984). Tumor cell heterogemeity in prumary and metastatic colorcctal carcinoma. In: Prot. Biod. Flinids 31, 1984 (Ed. H. Peeters), p. 587 594.

8. Arends JW, Wiggers $T_{1}$ Verstijnen $C_{\text {, Basman }} \mathrm{FT}$ (1986). The occurrence and clinicopathological signilicance of serotonin immunoreactive cells in large bowel carcinoma. J. Pathology 1.48: $97-102$.

9. Wiggers T, Arends JW, Verstijnen C, Mocrkerk PM and Bosman FT (1986). Prognostic significance of CEA immunoreactivity patterns in large bowel carcinoma tissue. $\mathrm{Br}$. J. Cancer 54: $409-414$.

10. De Boer-van den Berg MAG, Verstijnen CPHJ and Vermeer C (1986). Vitarmin K-dependent carboxylase in skin. J. Invest. Dermatol 87: $377-380$.

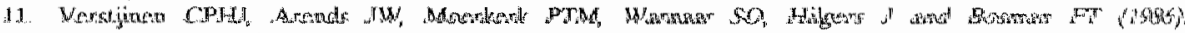

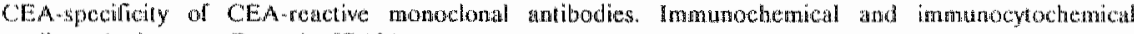
studics. Anticancer Res. 6. 97-104.

12. Arends JW, Schuthe B, Wiggers Th, Verstijnen CPHJ, Blijham GH, Basman FT, (1087) Comparison of phenolypic and gervorypic features in primuary large bowel carcinomas and lymphnode metastases. Cancer Res. 47: 4342-4344.

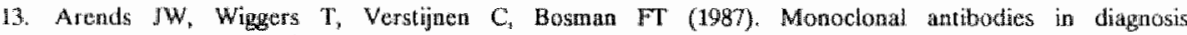
atud progacsis of colorectal cancer. In: Application of monoclonal antibodies in tumor pahology. (D) Ruiter, so Warnaur, GJ Fleuren, Eds.) Martinus Nijhof, The Hague, 1987, pp. 211. 222.

14. Varstünen CPHI, Arends JW, Moerkerk PTM, Geraedts JPM, Sekikanwa $K$ Uitendaal MP, Bosman FT (1987). The establishment and chatacterization of two new cell lines derived from a single hurnan colonic adenocarcinoma. Virch.Arch.B 53: 191-197.

15. Versijnen CPHJ "Ten Kate $J$, Arends JW, Schutte B, Bosman FT. (1987) Xenografing of normal colunic mucosa in athymic mice. J. Pathol. (Accepted for publication). 


\section{Abstracts}

1. Verstiper $C$, Arends JW, Moerkerk $P$ and Bosnan FT. Specincily of CEA-reactiwe monodonal antibodie: immunohistochemical and immunocytochenical sudies, J. Patbol. 1985: 146: $26 \% \mathrm{~A}$.

2. Verstinen CPH), Arends JW, Moerkerk PTM, Bosman FT (1986). Biochemical amd immumohistochemical characterzation of eight mucine reactive monoclonal antibodies. ISOBM XIV Annul Meeting, Helsink, Finland; 14-17 augustus 1986. Tumour Biol.

3. De Koning RW, Geerzen HGM, Sehute B, Versijnea C, Fevery J, van Hanum J, Janssens AR, Bosman FT (1986). Human hepatoma cell reactive anibodies in infurnatory liver disease. I. Hepatol. suppl. 1, wol. 3: $\$ 135$.

4. Arendis IW" Wiggers T, Verstijnen $\mathrm{C}$, Brosman FT (1986). The prognostic walue of mucin type detection in large bowel carcinoma. y. Pathol. 149: 212.

5. Simom REJ, Arends IW, Verstijnen $C_{n}$ Cleutjens J, Havenilh MC, Bosman FT (1986), Evidence for a murine stromal origin of basenent membranes in colonic carcinoma xemogralls in nude mice. Eur.J.Cell Blol. suppl. 11, vol. 39: 34.

6. Verstijnen C, Ten Kate J, Schute B, Reijnders M, Arends JW, Bosman Fr (1980). Xonografting of normal colonic mucosa into nude mice. J. Pathol. 151: 74A.

7. Verstignen CPHJ Arends JW, Moerkerk PTM, Bosman FT (1986). Biochemical and immunohisto. chemical characterization of eight mucin-reactive monoclonal antbodies. J. Histochem. Cyochem. 34: 1358 .

8. Versijnen $C$, Moerkerk $P$, Arends JW, Bosman FT (1986) Mucin reactive monoclonal antibodies: Immunocytochemical patterns and amtigen identification. Act. Hist. Cyt, 19:41.5.

9. Verstijnen CPHJ, Arends JW, Moerkerk PTM, Schutte B, w.d. Linden E, Kuypers B, Bosman FT. Kwek en xenograften van primaire coloncarcinome cellinnen: wergelijken van in vitro en in wiwo modellen the de primaire tumor. NPAV 10 oktober 1987 te Rotterdam. 


\section{DANKWOORD}

Het is duidelijk dat dit proefschrift niet tot stand zou zijn gekomen zonder de hulp van vele anderen. Een aantal mensen die een belangrijke rol hebben gespeeld bij het tot stand komen van dit proefschrift wil ik met name bedanken.

Tijdens de stimulerende gesprekken met Fré Bosman is de opzet van het onderzoek uitgewerkt en bij het schrijven van het boekje is zijn inbreng groot geweest. Jan Willem Arends heeft het project geschreven in het kader waarvan het onderzoek is uitgevoerd. De ideëen voor het onderzoek zijn met hem doorgesproken en zijn steun bij het schrijven van het boekje is van essentieel belang geweest. De referenten Prof. Dr. J.P.M. Geraedts, Prof. Dr. D.J. Ruiter en Dr. J. Hilgers wil ik bedanken voor het kritisch beoordelen van het manuscript. Samen met Peter Moerkerk is het KWF-project uitgevoerd. Peter heeft een essentiële bijdrage geleverd bij het opzetten en uitvoeren van het biochemisch en het weefselkweek werk. Bert Schutte en Michèle Geebelen-Reijnders van de afdeling interne geneeskunde hebben de flow cytometrische bepalingen verricht. De vele gesprekken met Bert Schutte en Joop ten Kate zijn altijd erg stimulerend geweest. Edith van der Linden is behulpzaam geweest bij het weefselkweekwerk en het werk met proefdieren. De vele immunohistochemische kleuringen zijn met veel zorg door Margriet Pijls en Birgit Engelen uitgevoerd. Jack Joosten wil ik bedanken voor zijn hulp bij het verkrijgen wan de weefsels. Frank Kornips van de afdeling Genetica en Celbiologie heeft het karyotype van de cellijnen bepaald. Paul Bomans en Judith Stouten hebben de EM opnamen verzorgd. Marie José Drittij en Martin Uitendaal van de afdeling farmacologie hebben de plating efficiëntie van enkele cellijnen bepaald, Koji Sekikawa heeft cell kinetische parameters ervan bepaald.

Marianne Rikers en Claire Bollen hebben de vele versies van het proefschrift uilgetypt en met name Marianne heeft met veel accuratesse de uiteindelijke versie van het proefschrift verzorgd. Cor Beek is behulpzaam geweest met programmering van de computer voor de lay-out van het boekje. Frans Weekers van de Centrale Proefdiervoorziening is behulpzaam geweest bij het opstarten van het proefdiermodel met thymusloze muizen en hij heeft de vele dieren verzorgd. De medewerkers van de audiovisuele dienst hebben de vele fotografische afdrukken verzorgd. Karin Daniels heeft de omslag ontworpen en de lay-out van het boekje verzorgd. Jannie Blijham wil ik bedanken voor de correctie van de Nederlandse samenvatting. 
Verder wil ik degene bedanken die een bijdrage hebben geleverd aan het tot stand komen van het boekje. De medewerkers van de afdeling Pathologie wil ik bedanken voor een goede samenwerking en een prettige werksfeer.

Tot slot wil ik familie en vrienden bedanken voor hun steun die zij voor mij geweest zijn. Met name mijn ouders wil ik bedanken dat zij mij altijd gestimuleerd hebben, en het mij mogelijk gemaakt hebben om te studeren.

\section{CURRICULUM VITAE}

Kees Verstijnen werd op 21 september 1953 te Tilburg geboren. In 1970 slaagde hij voor het MULO-B diploma aan de Albertus Magnus MULO te Geldrop en in 1972 voor het HBS-B diploma aan het Rijks Atheneum in Helmond. In 1972 begon hij met de studie biologie aan de Landbouwhogeschool in Wageningen. In 1975 onderbrak hij de studie voor het vervullen van de militaire dienstplicht.

In 1977 behaalde hij het kandidaats examen biologie waarna hij een aanvang maakte met het hoofdvak histologie onder leiding van Dr. J.H.W.M. Rombout en het bijvak dierfysiologie onder leiding van Dr. J.A.M. Matthey. In 1980 begon hij met het bijvak celbiologie op het Antoni van Leeuwenhoek huis te Amsterdam onder leiding van Dr. J. Hilgers. In maart 1982 behaalde hij het Doctoraal examen cn sindsdien is hij werkzaam op de afdeling Pathologie van de Rijksuniversiteit Limburg te Maastricht. 